UNIVERSIDADE DE BRASÍLIA

INSTITUTO DE CIÊNCIAS BIOLÓGICAS

DEPARTAMENTO DE BIOLOGIA CELULAR

PÓS - GRADUAÇÃO EM BIOLOGIA MOLECULAR

\title{
Produção de novos Anticorpos Anti-CD20 na forma de FvFc em Células de Mamíferos
}

\author{
Juan Fernando Riasco Palácios
}

Orientador: Ph.D. Andréa Queiroz Maranhão

Brasília - DF

2015 


\title{
Produção de novos Anticorpos Anti-CD20 na forma de FvFc em Células de Mamíferos
}

\author{
Juan Fernando Riasco Palácios
}

Orientadora: Ph.D. Andréa Queiroz Maranhão

Co -orientador: Prof. Dr. Marcelo de Macedo Brígido

Dissertação apresentada ao

Departamento de Biologia Celular do Instituto de Ciências Biológicas da Universidade de Brasília como Requisito parcial à obtenção do grau de Mestre em Biología Molecular

Brasília - DF

2015. 


\section{Banca Examinadora:}

Prof. a . Dra. Andréa Queiroz Maranhão (UnB - Presidente)

Prof. Dr. Marcelo de Macedo Brígido (UnB - Co-orientador)

Prof. Dr. Fernando Araripe Gonçalves Torres ((UnB - Membro Interno)

Prof $^{\text {a }}$. Dra. Talita Souza Carmos - (Membro Externo)

Dra.. Juliana Franco Almeida - (UnB - Suplente)

Trabalho desenvolvido no Laboratório de Biologia Molecular da Universidade de Brasília, sob a orientação do Prof. a Dra. Andréa Queiroz Maranhão 
Dedico este trabalho a minhas duas mães:

Germanny Palácio e Teresita Riascos, Meu pai Antônio Riasco (Q.E.P.D) e irmã, Andrea Riasco, minha Família, Por serem o motor da minha Amo vocês! 


\section{Agradecimentos}

Aos meus orientadores, Andréa Maranhão e Marcelo Brígido, pela oportunidade e confiança depositada em mim. Por todos os ensinamentos ministrados, por serem um exemplo a seguir de êxito profissional que espero alcançar no futuro, por terem me acolhido no grupo, mesmo vindo de longe e sem nem me conhecer e conhecer meu potencial e dedicação, de verdade, não tenho palavras para agradecer a grande oportunidade, que me permitiu crescer profissional e pessoalmente, além de conhecer um país tão belo como o Brasil, de todo coração quero agradecer infinitamente. Espero não ter decepcionado vocês!

Aos professores do Departamento de Biologia Celular do Instituto de Ciências Biológicas da UnB, obrigado pelas dicas e matérias ultra proveitosas, pelo incentivo, ensinamentos e auxílios prestados.

A todos e cada um de meus colegas do Laboratório 1, em especial a Rafael Burtet muito obrigado, por toda a sua paciência, ensinamentos ministrados, dicas e risadas. A Fernanda Bento, por todas as nossas conversas, risadas, muitas risadas, você é uma menina excepcional, você foi a primeira pessoa que me acolheu na bancada, mesmo eu atrapalhando, você sempre estava disposta a me ajudar, muito obrigado! Ao Thompson Tomatelli, sempre prestativo a todo momento. Ronny Peterson por todas besteiras que a gente conversou, graças a você consigo acompanhar uma conversa com o português enrolado. A Galina Gulhis por ser uma mãe dentro do laboratório, como sinto sua falta! A Maryani, Isabel, Maria Jose, Juliana, e antigos membros do laboratório, a todos vocês muito obrigado por me ajudarem desde o início deste processo, mesmo quando não nos entendíamos devido ao idioma, bom as vezes até agora, obrigado por me ensinarem um pouco de seu lindo Pais, língua, costumes e demais experiências que alimentaram minha vida.

Aos meus amigos, principalmente a meu grande amigo, irmão, Nestor Fabian Leyton por sempre ter a palavra perfeita no momento oportuno, por ser essa mão amiga, esse ombro em que posso me apoiar, por todas nossas risadas mesmo nos momentos mais difíceis, estamos

juntos meu irmão, estamos conseguindo nossos sonhos. A Miguel Eduardo Guevara e Karen Robles, por serem a minha família que a vida me deu, graças a forca da distância. 
A Larissa Polyana Pedroza, por seu apoio, ajuda, compreensão, por me suportar, nesta etapa final, pelos risos e cuidados, muito, muito obrigado, você é um tesouro que achei neste caminho, que a vida te devolva tudo de bom que você dedica ao próximo, a sua família por seu carinho e apoio.

Agradeço também a Dona Fátima e Dona Ivonildes pelo carinho e atenção, por serem tão legais comigo, por cuidarem do laboratório, dos nossos reagentes e materiais.

A Universidade de Brasília por ter me acolhido durante este tempo e por me permitir avançar na minha carreira de cientista.

E a todas as pessoas que de alguma forma ajudaram na consecução e realização deste grande sonho. MUITO OBRIGADO! 


\section{Sumário}

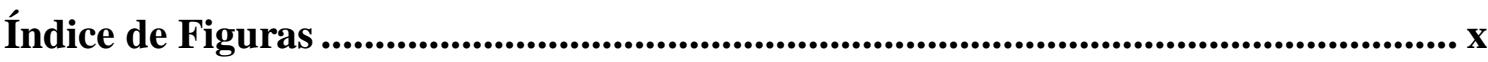

Índice de Tabelas ................................................................................................................. xii

Lista de Termos e Abreviaturas.......................................................................... xiii

Resumo

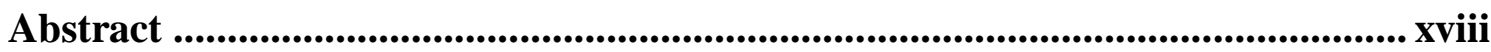

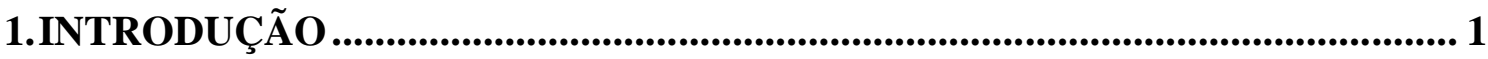

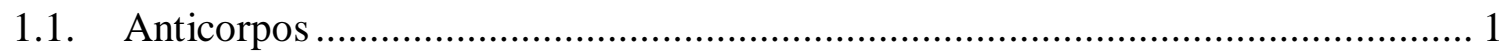

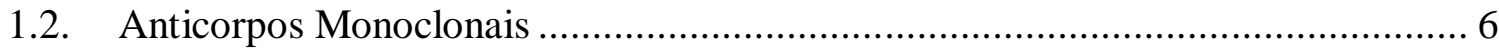

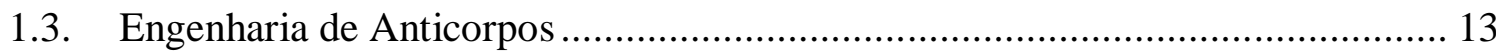

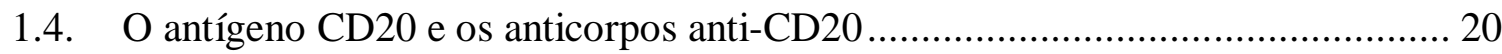

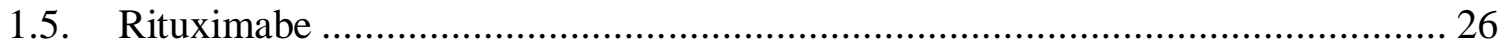

1.6. Expressão Em Células De Mamífero ………………………………………... 27

2.OBJETIVOS....................................................................................................................... 33

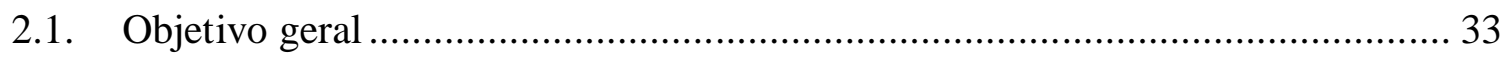

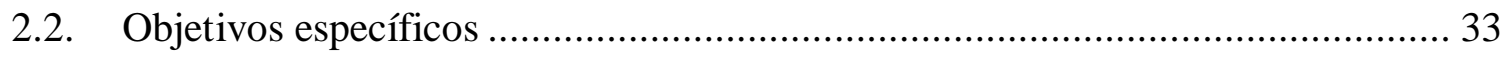

3.MATERIAIS …............................................................................................................. 34

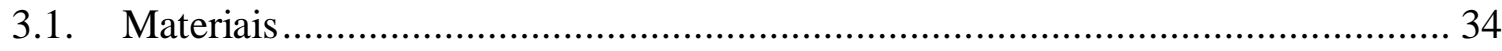

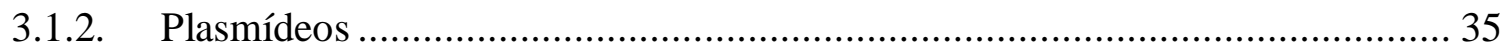

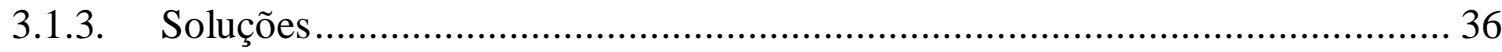

3.1.4. Meios De Cultura Para Bactérias ....................................................................... 36

3.1.5. Meios de cultura e soluções para cultura de células de mamíferos.................... 37

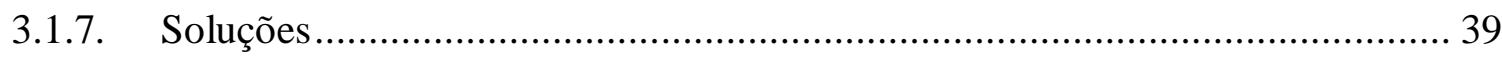

3.1.8. Soluções e material para preparo de células competentes e transformação

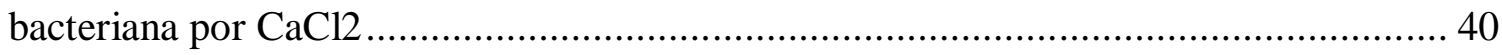


3.1.9. Soluções Para Extração De DNA Plasmidial ..................................................... 41

3.1.10. Tampões de Endonucleases de Restrição....................................................... 42

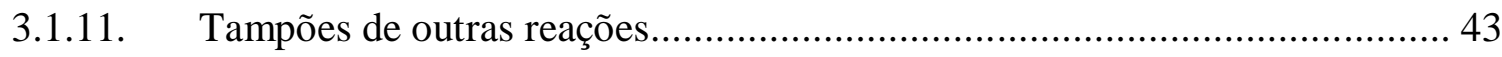

3.1.12. Endonucleases de restrição......................................................................... 44

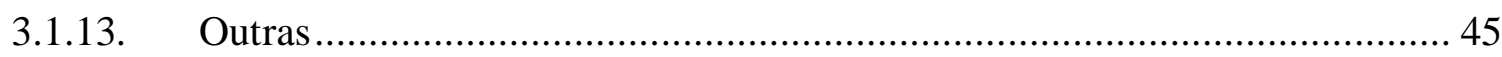

3.1.14. Soluções e reagentes para eletroforese ………………………………….... 45

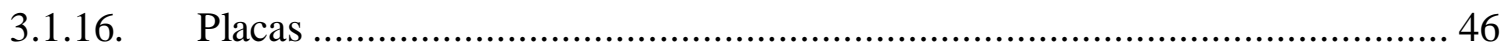

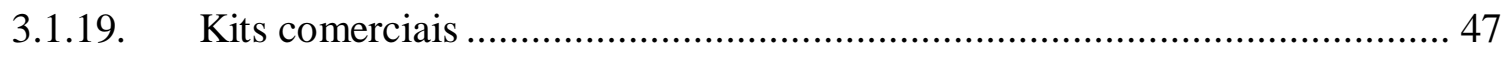

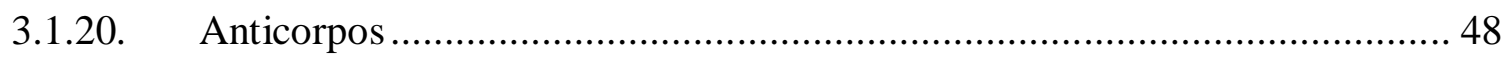

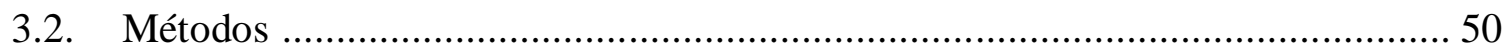

3.2.1. Preparação de DNA plasmidial..................................................................... 50

3.2.2. Em pequena escala (adaptado de Sambrook e Russel, 2001) .......................... 50

3.2.3. Em larga escala (adaptado de Sambrook e Russel, 2001)............................... 51

3.2.4. Digestão de DNA plasmidial com endonucleases de restrição........................... 53

3.2.5. Análise de DNA plasmidial em gel de agarose (Sambrook e Russel, 2001).... 53

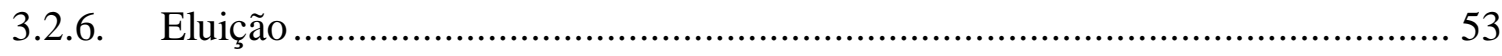

3.2.7. Reação de Desfosforilação com a fosfatase alcalina de camarão (SAP)........... 54

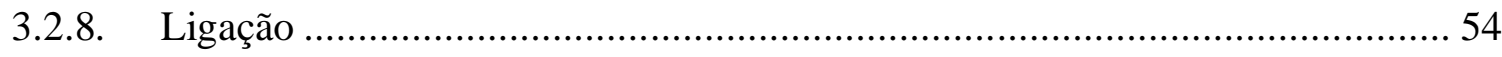

3.2.10. Por choque térmico- $\mathrm{CaCl}_{2}$ (adaptado de Maranhão, 2003 ............................ 55

3.2.11. Por eletroporação (adaptado de Maranhão, 2003)......................................... 56

3.2.12. Condições e preparo da Reação em Cadeia da Polimerase (PCR) ................. 57

3.2.13. Cultura de células de mamíferos ............................................................. 59

3.2.13.1.1. Congelamento de células de mamíferos - Criopreservação ........................ 60

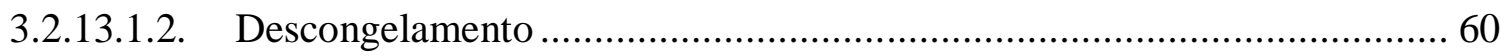

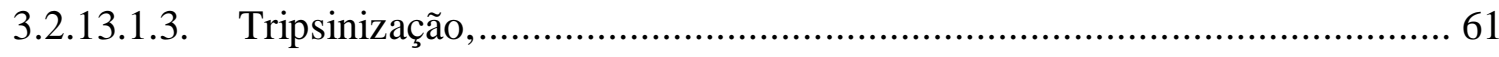


3.2.13.1.4. Estimativa do número de células por meio de contagem em câmara de

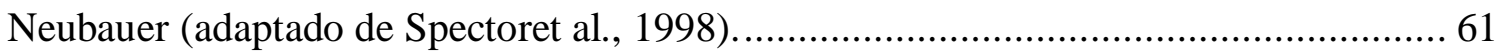

3.2.13.1.5. Determinação Viabilidade celular (adaptado de Spectoret al., 1998) ........ 62

3.2.13.2. Transfecção de células CHO-K1 e HEK-293 utilizando o reagente JetPEI ${ }^{\mathrm{TM}}$ (PolyplusTransfection, no de catálogo 101-01N). 62

3.2.13.3. Seleção de células transfectadas utilizando Geneticina® (G418-Sulfato)..... 63

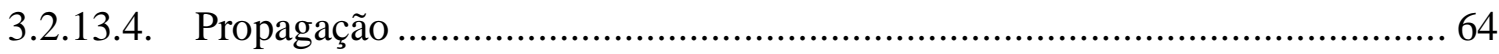

3.2.14. ELISA (Enzyme-linked immunosorbent assay)................................... 65

3.2.15. Purificação de Proteínas com a coluna ImmunoPure Plus Immobilized Protein A (Pierce $\left.{ }^{\circledR}\right)$ 67

3.2.16. Análise de proteínas em gel de poliacrilamida desnaturante (adaptado de Silva-

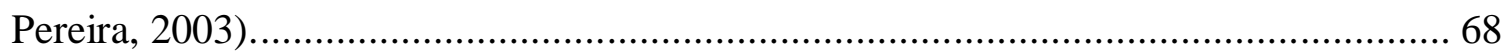

Coloração do gel SDS- PAGE com o kit comercial Proteo Silver Stain da Sigma. ........ 69

3.2.17. Eletroforese em Gel através de Microchip (Método GelChip-CE) .............. 69

4. RESULTADOS E DISCUSSÃO ................................................................ 72

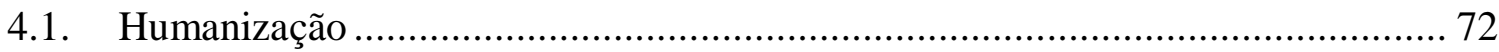

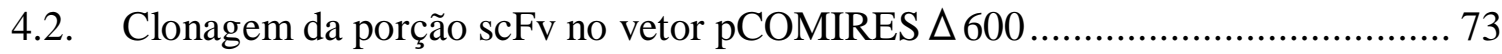

4.3. Transfecção em células de ovário de Hamster Chinês (CHO) e de Rim Embrionário

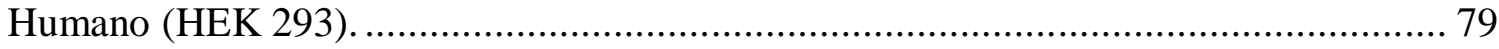

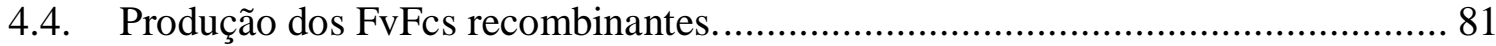

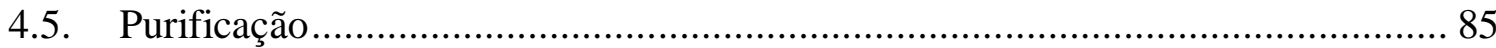

5. CONCLUSÕES E PERSPECTIVAS ...............................................................91

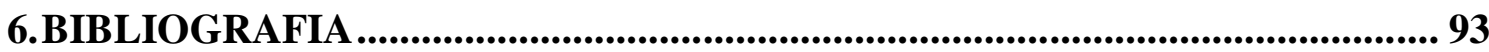




\section{Índice de Figuras}

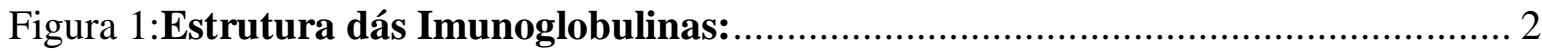
Figura 2 :Representação das distintas regiões determinantes de complementaridade: . 3 Figura 3: Nomenclatura de anticorpos recombinantes obtidos por engenharia genética. 5

Figura 4: Representação esquemática de anticorpos quiméricos e humanizados . ...... 16 Figura 5.Construção de uma biblioteca de fagos para geração de anticorpos monoclonais: 18

Figura 6 : Representação esquemática da seleção guiada usando-se a técnica de chain shuffling. 19

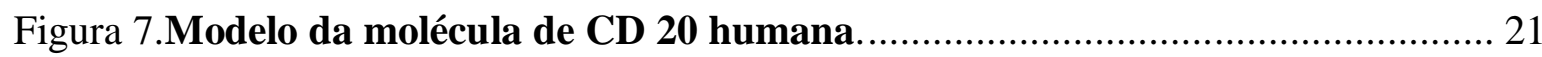

Figura 8. Representação esquemática da forma de atuação dos anticorpos anti-CD20 de tipo I e II. 25

Figura 9: Recrutamento dos mecanismos efetores imunes por meio do domínio Fc

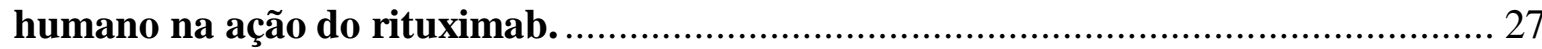

Figura 10 Mecanismo de ação do sítio de entrada ribossomal interno. ........................ 29

Figura 11: Representação gráfica do mapa físico do vetor pCOmires $\Delta 600$ antiCD3

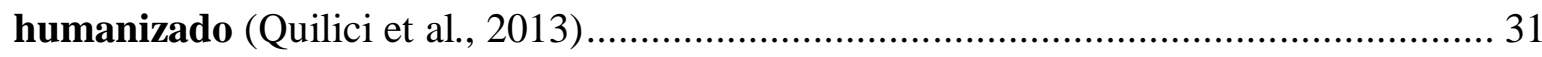

Figura 12: Estratégia para construção do vetor pCO $\Delta 600 \mathrm{FvFc}$ hibrido. ………....... 74

Figura 13:Analises Perfil de restrição dos Plasmídeos; pBSK-ScFvHibridoRitux-

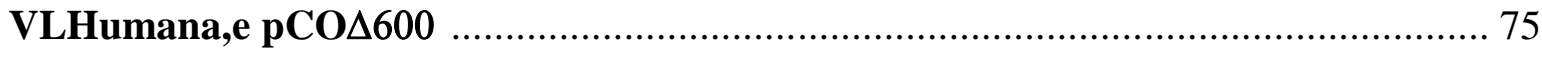

Figura 14: Desenho esquemático da versão do vector pCO $\Delta 600 \mathrm{FvFc}$ Hibrido $(\mathbf{H}), . .76$

Figura 15: Confirmação da c a construção pCO $\Delta 600$ FvFc Hibrido (H)................... 77

Figura 16: Desenho esquemático dos primers utilizados para confirmação das clonagens

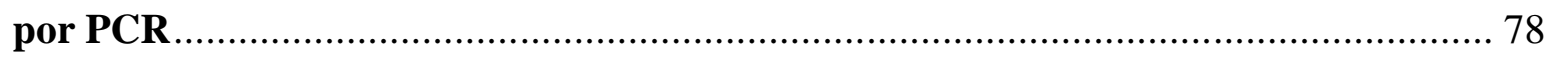

Figura 17: Análises em Gel de agarose 1 \% com o resultado da PCR da construção pCO

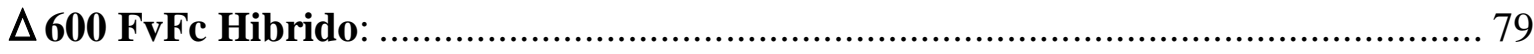

Figura 18: Eficiência de transfecção das células de mamífero....................................... 81

Figura 19: Níveis de produção dos anticorpos nos sobrenadante de cultura................. 83 
Figura 20: Imunodetecção dos FvFcs após purificação e concentração...................... 86

Figura 21: Curva-padrão para quantificação por ELISA...................................... 86

Figura 22: Análise da purificação dos FvFc por GelChip-CE. Bioanalyzer............... 89

Figura 23. Análise dos FvFcs produzidos por Western Blot: .................................. 90 


\section{Índice de Tabelas}

Tabela 1. Anticorpos monoclonais aprovados pelo FDA até 2015. Adaptada do site da Food Drug Administration ............................................................................. 7 Tabela 2 Anticorpos anti-CD20 aprovados ou em fases de teste clínico. Adaptada do site

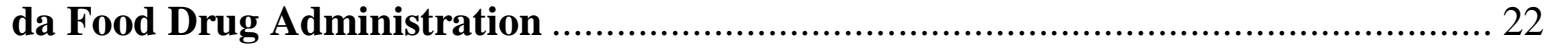

Tabela 3: Condições da PCR ................................................................................... 58

Tabela 4: Porcentagem de pureza de FvFc purificados......................................... 89 


\section{Lista de Termos e Abreviaturas}

\begin{tabular}{|c|c|}
\hline ADCC & Citotoxicidade celular mediada por anticorpos \\
\hline APS & Persulfato de Amônio. \\
\hline BCIP & 5-Bromo-4-Cloro-indolil fosfato. \\
\hline Bret & Brometo de Etídeo. \\
\hline BSA & Albumina bovina sérica. \\
\hline${ }^{\mathbf{o}} \mathbf{C}$ & Graus Celsius. \\
\hline C-terminal & Extremidade Carboxi- terminal \\
\hline CDC & Citotoxicidade Depende de complemento \\
\hline CDR & Região determinante de complementaridade. \\
\hline CH1, 2, 3 & Domínios constantes da cadeia pesada de um anticorpo. \\
\hline $\mathbf{C L}$ & Domínio constante da cadeia leve de um anticorpo. \\
\hline CMV & Citomegalovírus \\
\hline Da & Dalton. \\
\hline $\mathbf{d H}_{2} \mathrm{O}$ & Agua Destilada \\
\hline DMSO & Dimetilsulfoxido \\
\hline DNA & Ácido desoxirribonucléico. \\
\hline dNTP & Desoxirribonucleotídeo. \\
\hline DTT & Ditiotreitol \\
\hline EDTA & Ácido Etilenodiaminotetracético. \\
\hline Fab & Fragmento de anticorpo de ligação ao antígeno. \\
\hline FACS & Fluorecencense Activeted Cell Sorter \\
\hline Fc & Fragmento cristalizável de anticorpo (porção constante). \\
\hline $\mathbf{F c R}$ & Receptor de Fc \\
\hline FDA & Food and Drug Administration (EUA) \\
\hline FITC & Fluoresceína isotiocianato \\
\hline FL & Fluorescência \\
\hline $\mathbf{F R}$ & Arcabouço (Framework) \\
\hline $\mathbf{F v}$ & Fragmento variável do anticorpo. \\
\hline FvFc & Fragmento variável fusionado ao Fc. \\
\hline
\end{tabular}




\begin{tabular}{|c|c|}
\hline g & Grama. \\
\hline$g$ & Gravidade. \\
\hline h & Hora. \\
\hline HACA & Human "anti-chimeric antibody" \\
\hline НАНА & Human "anti-Humanized Antibody" \\
\hline НАМА & Human "anti-mouse Antibody" \\
\hline HEK & Células embrionárias de rim humanc \\
\hline IA & Íntron A \\
\hline Ig & Imunoglobulina. \\
\hline $\mathbf{k b}$ & Quilobase. \\
\hline kDa & Quilodalton. \\
\hline $\mathbf{k V}$ & Quilovolts. \\
\hline $\mathbf{L}$ & Litro. \\
\hline $\mathbf{M}$ & Molar. \\
\hline$\mu g$ & Microgramas. \\
\hline$\mu \mathbf{l}$ & Microlitros. \\
\hline $\boldsymbol{\mu} \mathbf{F}$ & Microfaraday. \\
\hline$\mu \mathbf{m}$ & Micrômetro. \\
\hline $\boldsymbol{\mu} \mathbf{M}$ & Micromolar. \\
\hline $\mathbf{m A}$ & Miliamper. \\
\hline $\mathbf{m A b}$ & Anticorpo monoclonal. \\
\hline mg & Miligrama. \\
\hline $\min$ & Minuto. \\
\hline $\mathbf{m L}$ & Mililitro. \\
\hline $\mathbf{m M}$ & Milimolar. \\
\hline $\mathbf{M M}$ & Massa molecular. \\
\hline mRNA & Ácido Ribonucléico mensageiro. \\
\hline NBT & Nitro Blue Tetrazole. \\
\hline ng & Nanograma. \\
\hline $\mathbf{n m}$ & Nanômetros. \\
\hline $\mathrm{OD}_{600}$ & Densidade ótica a 600ๆm. \\
\hline
\end{tabular}




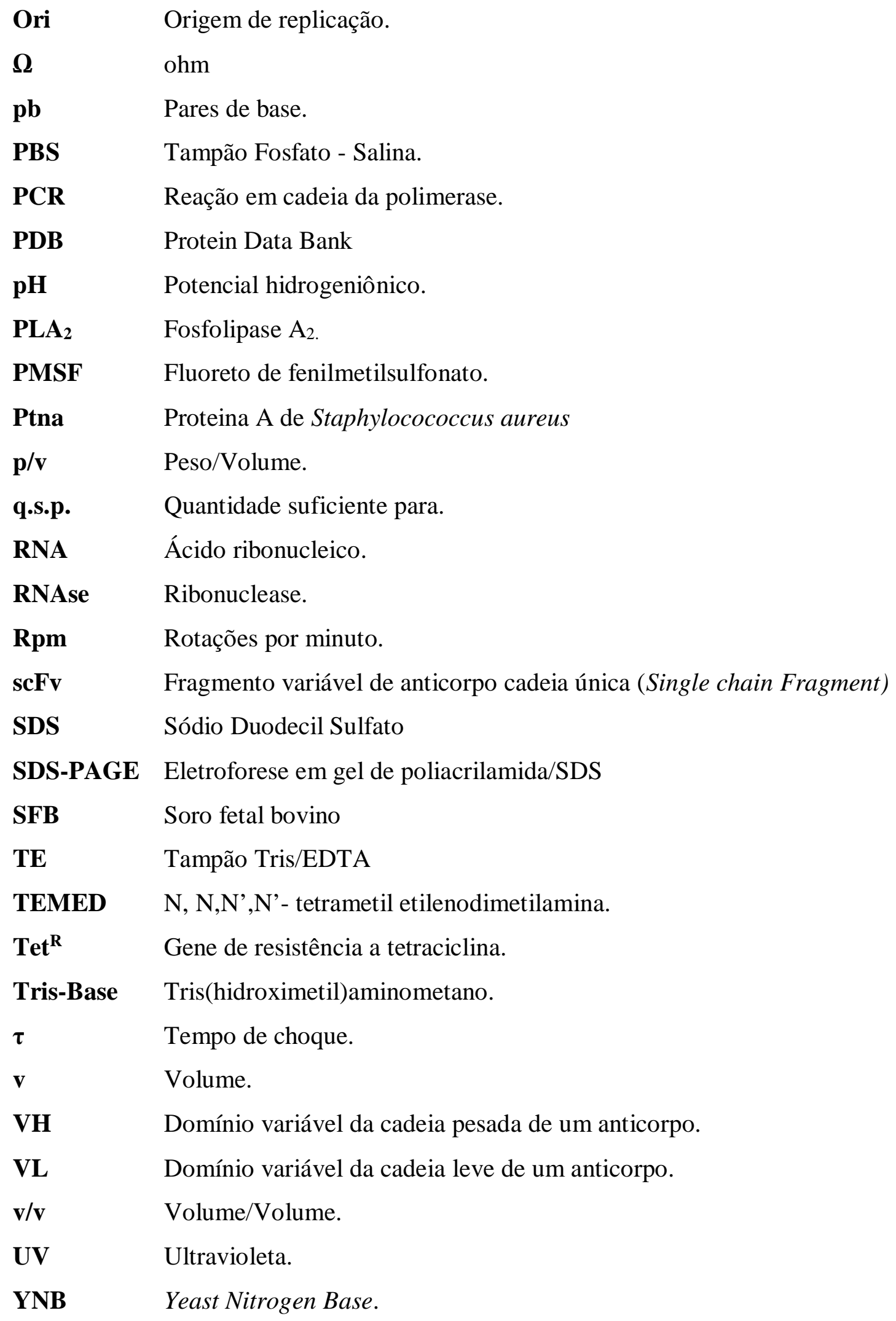




\section{Resumo}

Os anticorpos monoclonais são glicoproteínas especializadas com capacidade de reconhecer outras moléculas (antígenos). Eles são ferramentas importantes na clínica e biotecnologia e têm sido úteis no diagnóstico e tratamento de doenças infecciosas, inflamatórias, imunológicas e neoplásicas, assim como no estudo da interação patógeno/ hospedeiro, e na detecção e quantificação de diversas moléculas. Os anticorpos monoclonais murinos (mAb) apresentam aplicações terapêuticas limitadas devido à sua natureza heteróloga, que pode gerar respostas imunogênicas e consequente a perda de atividade. A incorporação de técnicas de biologia molecular, e engenharia genética e proteomica tem aumentado a produção e utilização de anticorpos monoclonais, desenvolvendo técnicas como hibridoma, quimerização, e humanização de anticorpos monoclonais totalmente humanos. Ao longo dos últimos anos, novas gerações de anticorpos monoclonais (mAbs) anti-CD20 têm sido desenvolvidas para potenciais vantagens sobre a clássica e primeira geração do mAb rituximabe, Apesar de seus sucessos, nem todos os pacientes respondem ao tratamento com rituximabe e quase todos tem um recaída em seu tratamento. Assim, melhorar as propriedades deste anticorpo para melhorar a sua eficácia é muito desejável. Comparado com o rituximabe, novos mAbs têm atividade anti-tumor melhorada, resultante do aumento da citotoxicidade dependente do complemento (CDC) e / ou citotoxicidade celular dependente de anticorpo (ADCC). Neste aspecto, cultivos de células animais são os sistemas de expressão para essas proteínas preferenciais, que requerem modificações pós-tradução. É assim que o grupo de Imunologia Molecular da Universidade de Brasília tem se interessado pela produção de proteínas heterólogas de interesse clínico em células de mamíferos desde 2001.

Este trabalho teve como objetivo a produção de novos anticorpos anti CD-20 na forma de fragmento recombinante $\mathrm{FvFc}$ em sistema de expressão heteróloga em células de ovário hamster chinês (CHO-K1) e em células de rim embrionário humano (HEK-293). A eficiência de transfecção para ambas as linhagens celulares foi avaliada comparativamente, bem como a expressão transiente. Os resultados indicam as células de mamífero como um sistema ótimo para a produção de proteínas heterólogas, Os segmentos dos genes correspondentes a três versões recombinantes humanizadas homologas ao anticorpo monoclonal quimérico rituximabe obtidas por CDR graffting (Zaparolli 2015) A, O, e L) e uma versão híbrida 
elecionada por VL shuffling $(\mathrm{H})$, foram amplificados e clonados num vetor de expressão para células de mamífero. Os resultados mostraram uma eficiência de transfecção e produção de anticorpos menor na linhagem de células CHO-K1 em comparação com HEK-293, embora estas fossem estáveis para a produção de anticorpo em transfectomas estáveis. Os anticorpos recombinantes produzidos foram purificados por cromatografia de afinidade, quantificados por ELISA, e analisados em relação a sua qualidade por SDS-PAGE, eletroforese capilar (Bioanalyzer) e Western Blotting. Os resultados deste projeto têm demostrado que fomos bem sucedidos na expressão e produção das construções humanizadas do anticorpo antiCD20. 


\begin{abstract}
Monoclonal antibodies are specialized which have the ability to recognize other molecules (antigens). They are important tools in clinical practice and biotechnology and have been useful in the diagnosis and treatment of infectious, inflammatory, immunological and neoplasic diseases, as well as in the study of the host/pathogen interaction, and in the detection and quantification of diverse molecules. Murine monoclonal antibodies (mAb) present limited therapeutic applications because of their heterologous nature, which can generate immunogenic responses and consequent loss of activity. The incorporation of molecular biology, proteic and genetic engineering have extended the production and uses of monoclonal antibodies, finding techniques like hybridoma, chimerization, humanization and fully human monoclonal antibodies. Over the last few years, new generations of anti-CD20 monoclonal antibodies (mAbs) have been developed for potential benefits over the classical, first-generation $\mathrm{mAb}$ rituximabe. Despite its successes, not all patients respond to rituximabe therapy and virtually all relapse. Improving the properties of rituximabe to enhance its efficacy further is therefore highly desirable. Compared with rituximabe, new mAbs have enhanced antitumor activity resulting from increased complement-dependent cytotoxicity (CDC) and/or antibody-dependent cellular cytotoxicity (ADCC). In this aspect animal cell, cultures are the preferential expression systems for those proteins, which require extensive posttranslational modifications. Our research group has been interested in the production of heterologous proteins in mammalian cells since 2001.
\end{abstract}

This work aimed the production of new antibodies anti CD-20 as a recombinant FvFc fragment, in heterologous expression system Chinese hamster ovary cells (CHO-K1) and Human Embryonic Kidney cells (HEK-293) the transfection efficiency for both cell lines was comparatively evaluated, as well as the transient expression. The results indicate mammalian cells as an optimal system for the production of heterologous proteins, Were amplified and cloned into an expression vector for mammalian cells the corresponding gene segments the three recombinant versions humanized homologous to monoclonal quimeric Rituximabe antibody obtained by CDR graffting (Zaparolli 2015) A,O and L) and a hybrid version selected by VL shuffling $(\mathrm{H})$. The results showed a lower transfection efficiency 
and production of antibodies in the CHO-K1 cell lineage compared to HEK-293 cells, although these were stable for the production of antibody in stable transfectomas. The antibodies were purified by affinity chromatography were analyzed by ELISA, SDS-PAGE, capillary electrophoresis (bioanalyzer) and Western Blotting, for the production and quality of intact immunoglobulin. The results of this project have shown that we have succeeded in the expression and production of humanized constructs anti-CD20 antibody. 


\section{INTRODUÇÃO}

\subsection{Anticorpos}

O sistema imune tem como principal finalidade a conservação da homeostasia do organismo, mantendo vigilância e defesa do organismo contra as doenças infecciosas, e agentes patógenos. A homeostasia consiste na manutenção do equilíbrio interno, enquanto a vigilância corresponde à identificação do que é próprio ou não do organismo. O sistema imunitário é constituído por dois tipos de respostas a antígenos. A primeira é a resposta imunitária celular, que depende de uma comunicação química especializada entre diferentes linhagens de células do sistema imunológico (células T e fagócitos, tais como os macrófagos, neutrófilos, etc.). A segunda compreende uma resposta imunitária humoral, a qual envolve a produção de imunoglobulinas.

Os anticorpos (Ac) ou imunoglobulinas (Ig) são glicoproteínas que possuem uma massa molecular em torno de $150 \mathrm{kDa}$. Esses anticorpos são compostos por dois tipos de cadeias polipeptídicas: uma chamada de cadeia pesada $(\mathrm{H})$ e outra chamada de cadeia leve (L) (Janeway et al., 2001; Jayapal et al., 2007). As glicoproteínas têm a capacidade de se ligar a antígenos específicos e recrutar sistemas efetores para eliminá-los. A classe mais comum e abundante de imunoglobulina é a IgG, sendo, inclusive, predominante entre os anticorpos de uso terapêutico (Fekete et al., 2013; Kim et al., 2005).

Cada IgG é formada por duas cadeias leves e por duas cadeias pesadas idênticas entre si. Cada cadeia leve é composta de uma porção variável (VL) e uma porção constante (CL). As cadeias pesadas e leves são unidas entre si por pontes dissulfeto formadas entre resíduos cisteina na porção carboxi terminal da cadeia leve e o domínio $\mathrm{CH} 2$ da cadeia pesada, cada cadeia pesada é composta de uma porção variável $(\mathrm{VH})$ e três ou quatro porções constantes (CH1, CH2 e CH3 CH4) para alguns subtipos IgG1 (Figura 1)

As regiões variáveis e o primeiro domínio constante da cadeia pesada ( $\mathrm{VH}$ e CH1) são associadas com cadeias leves (VL e CL) para formar dois fragmentos de ligação ao antígeno chamados de fragmentos Fab. Cada fragmento contém Regiões Determinantes de Complementaridade - CDRs, sendo três fornecidas pela cadeia leve e três pela cadeia pesada que juntas formam os sítios de ligação ao antígeno, o paratopo. Este corresponde a uma 
superfície complementar ao epítopo (região que é reconhecida no antígeno) e define sua especificidade (Abbas et al., 2014) que interage diretamente com um antigéno específico, sendo os CDR3 os que mais diretamente interagem com ele e a mais variavel (Figura 1). Além disso, as regiões $\mathrm{CH} 2$ e $\mathrm{CH} 3$ das cadeias pesadas formam a fração cristalizável ou fragmento $\mathrm{Fc}$, região que tem funções efectoras, tais como a melhoria do transporte placentário, fortalecimento de fagocitose (opsonização) ou citotoxicidade celular dependente de anticorpo (ADCC). Nos anticorpos além das quatro cadeias polipeptídicas aparecem um componente glicosídico no domínio.

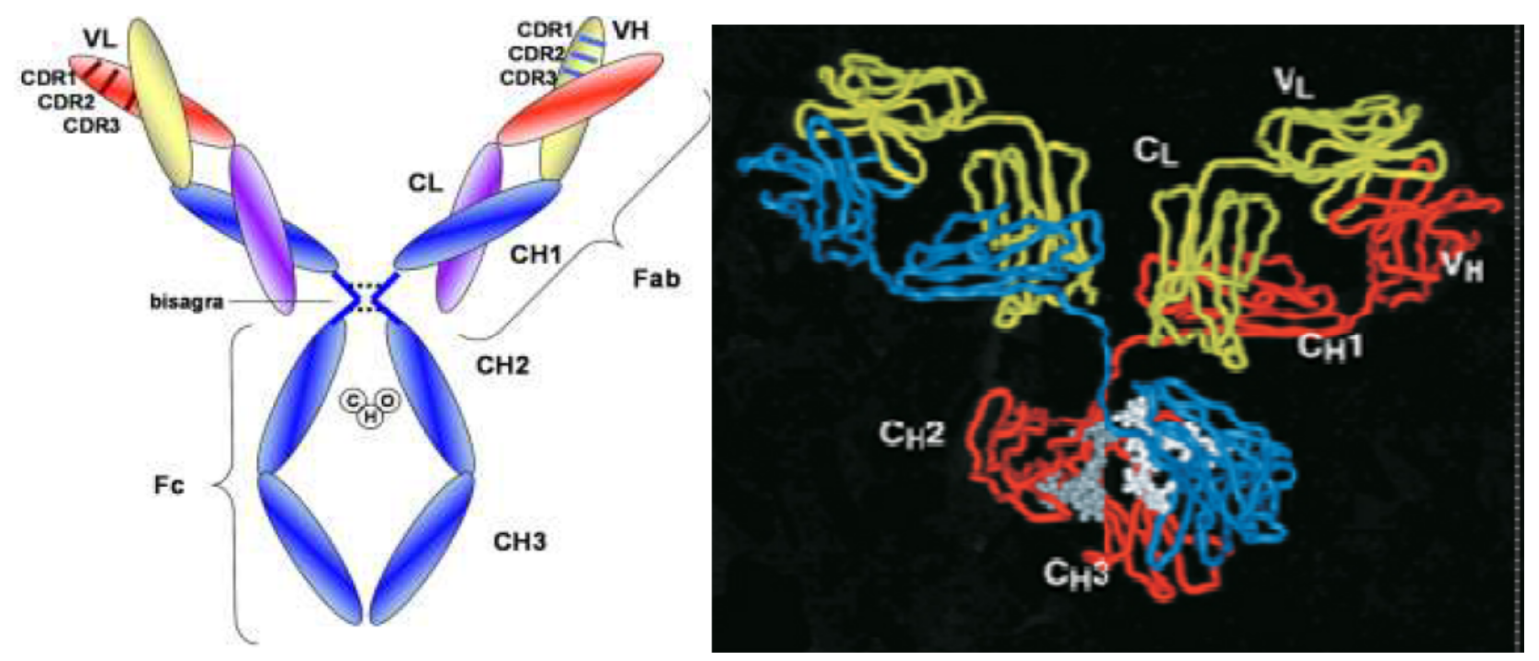

Figura 1:Estrutura dás Imunoglobulinas: A) diagrama esquemático de uma IgG. Secretada; B) cristalografia de raios X, cadeias pesadas em azul e vermelho, cadeias leves em verde; os carboidratos em cinza. FONTE: Elsevier. Abbas et al. <www.studentconsult.com>.

Uma molécula de $\operatorname{IgG}$ ao ser clivada proteoliticamente por papaína na região bisagra gera duas moléculas constituídas da cadeia leve ligadas ao fragmento VH-CH1 da cadeia pesada chamadas de Fab (Fragmento de ligação ao antígeno), ocorrendo a liberação do fragmento cristalizável $(\mathrm{Fc})$ após a clivagem

A área de interação entre o anticorpo e o antígeno é no interior da região variável, nas regiões hipervariáveis, destacando sua maior contribuição nessa interação. Essas regiões hipervariáveis de imunoglobulina formam laços (CDRs) que estão expostos na superfície molecular e permitem a interação do anticorpo com o antígeno. A maior superfície de contato entre as duas moléculas é no CDR3 Desta forma, a sequência de aminoácidos das regiões hipervariáveis é a responsável, em última instância, pela especificidade da ligação do 
anticorpo. No entanto, no reconhecimento de antígenos de tamanho pequeno (açúcares simples, por exemplo) pode ser que mais CDRs fiquem fora da zona de contato, portanto não participam em sua união. Neste momento, os FRs, do inglês frameworks, compostos por 105 aminoácidos, os quais são regiões que exibem menos variabilidade, conhecidas como regiões de arcabouço também podem interagir com o antígeno (Fekete et al., 2013; Stank and Goldsby, 2000), (Figura 2). A capacidade das imunoglobulinas para interagir com proteínas nativas é uma diferença importante em comparação com outras moléculas do sistema imunológico envolvido na ligação ao antígeno.

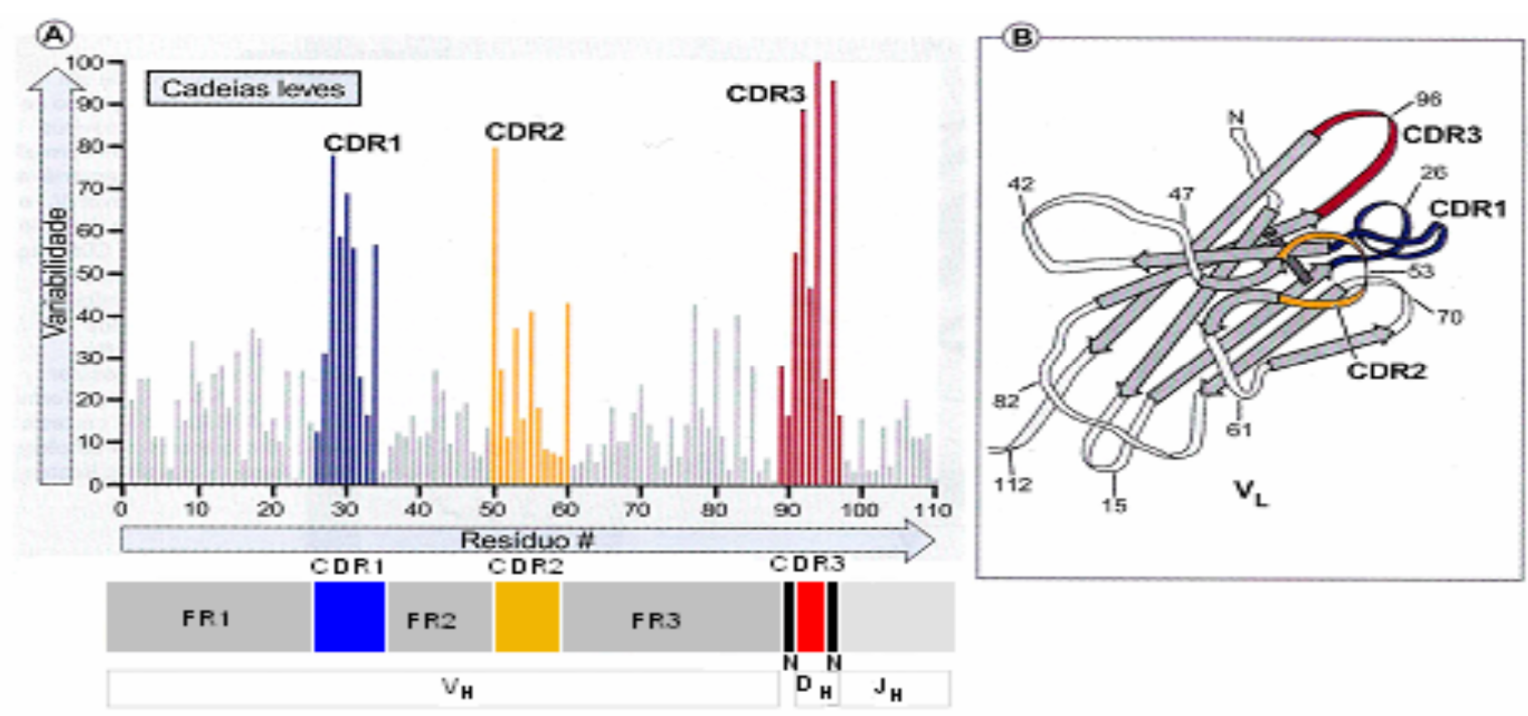

Figura 2 :Representação das distintas regiões determinantes de complementaridade: Representação da variabilidade em cada posição das distintas regiões determinantes de complementaridade dos segmentos VH (CDR1, CDR2, CDR3). No esquema inferior, a região variável do gene IgH rearranjado, interrompida por três regiões do arcabouço (framework) de aminoácidos relativamente conservados. A região CDR3 é a mais hipervariável e compreende a sequência que resulta da união dos segmentos gênicos $\mathrm{VH}-\mathrm{DH}-\mathrm{JH}$, além dos segmentos $\mathrm{N}$ (barras pretas) inseridas durante a recombinação. B - Estrutura molecular da região variável da cadeia leve VL com três alças das CDRs. Fonte: Adaptação de Kuby, 2002.

Os anticorpos possuem dois tipos de cadeia leve denominadas "lambda" $(\lambda)$ e "kappa"

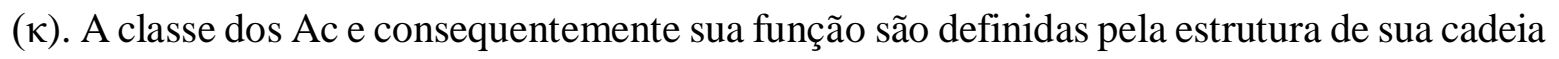
pesada. Existem cinco principais classes ou isótipos de cadeia pesada, que determinam a atividade funcional da molécula do anticorpo. Assim, a cadeia pesada se subdivide em: $\alpha, o$, $\varepsilon$, Y e $\mu$, que diferenciam as cinco classes de imunoglobulinas em IgA, IgD, IgE, IgG e IgM, respectivamente. Em seres humanos, os isótipos IgA e IgG ainda podem ser subdivididos em subclasses relacionadas, ou subtipos, chamados de IgA1 e IgA2; IgG1, IgG2, IgG3 e IgG4 
(Brodsky, 2009; Fekete et al., 2013; Miller, 2004). O principal e mais abundante anticorpo do soro é o IgG, o qual é o mais utilizado para fins terapêuticos (Neuberger et al., 2000) (Brodsky, 2009).

Os genes que codificam as cadeias leve e pesada das imunoglobulinas são organizados em segmentos gênicos. Os genes da cadeia leve de mamíferos contêm os segmentos V, J e C. O primeiro segmento gênico, V, codifica os primeiros 97 aminoácidos da região variável da cadeia leve. Existem cerca de 300 sequências V diferentes agrupadas em tandem no genoma de camundongo. $\mathrm{O}$ segundo segmento, J, consiste de 4 ou 5 sequências de DNA possíveis que codifica os últimos 15-17 resíduos de aminoácidos da região variável. O terceiro segmento gênico, $\mathrm{C}$, codifica a região constante da cadeia leve. Durante a maturação da célula B na medula óssea, um dos 300 segmentos $\mathrm{V}$ e um dos 5 segmentos $\mathrm{J}$ são combinados para formar a região variável leve do gene de anticorpo (Hozumi and Tonegawa, 1976) (Papavasiliou and Schatz, 2002). Os genes da cadeia pesada possuem ainda mais segmentos que os da cadeia leve: V, D, J e C. O Domínio variável da cadeia pesada são constituídos por um segmento V (200 sequências diferentes codificando os primeiros 97 resíduos de aminoácidos), um segmento D (10-15 sequências diferentes codificando mais 314 aminoácidos), e um segmento J (4 sequências para os últimos 15-17 aminoácidos da região variável). O próximo segmento, $\mathrm{C}$, codifica a região constante. A porção variável da cadeia pesada é formada pela junção de um segmento $\mathrm{V}$, um $\mathrm{D}$ e um $\mathrm{J}$ do anticorpo (Hozumi e Tonegawa, 1976), (Schatz and Ji, 2011).

Dessa forma, uma molécula de imunoglobulina é formada a partir de dois genes criados durante a fase antígeno-independente do desenvolvimento do linfócito B. Cerca de $10^{3}$ cadeias leves diferentes e por volta de $10^{4}$ cadeias pesadas diferentes podem ser formadas. Visto que cada uma é formada independente da outra, cerca de $10^{7}$ tipos de imunoglobulinas podem ser criados a partir da combinação das cadeias leve e pesada na célula. Cada célula $B$ produz apenas um dos $10^{7}$ tipos de anticorpos possíveis (Bassing et al., 2002; Gilbert 2006; Jung and Alt, 2004).

Atualmente é possível desenhar sequências que codificam fragmentos de anticorpos e gerar diferentes modelos de fragmentos utilizando-se técnicas moleculares de manipulação de DNA. Um dos modelos mais utilizados é o scFv que consiste no VH ligado ao VL por um 
peptídeo conector flexível ((Gly4Ser)3, por exemplo) com o intuito de mimetizar a região Fv do anticorpo e manter sua especificidade(MARANHÃO and BRÍGIDO, 2001). Como vantagens, devido ao seu tamanho reduzido, ele possui alto poder de penetração em tecidos, facilitando a ação, por exemplo, dentro de tumores sólidos (Holliger and Hudson, 2005). Já no caso da ação efetora pode-se utilizar a molécula formada por duas porções variáveis ligadas à porção Fc, forma conhecida como FvFc (Figura 3).

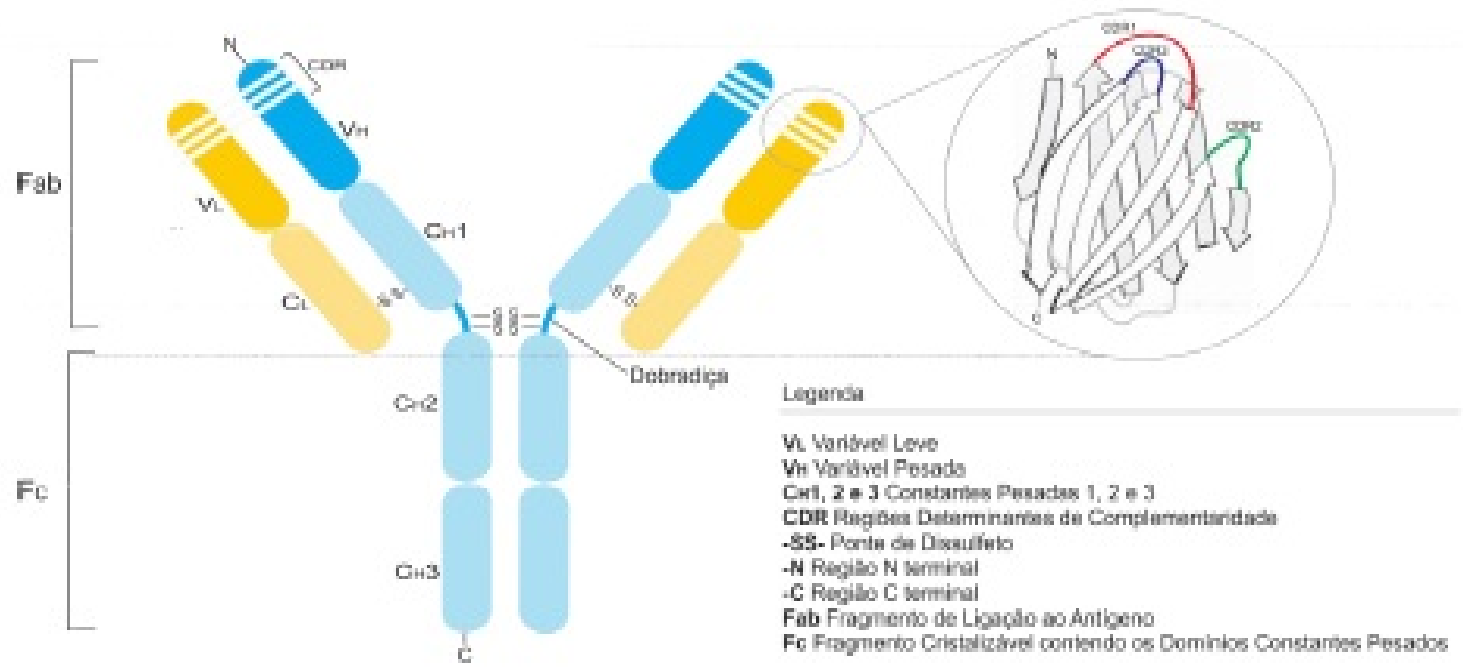

\section{Fragmentos de Anticorpo}
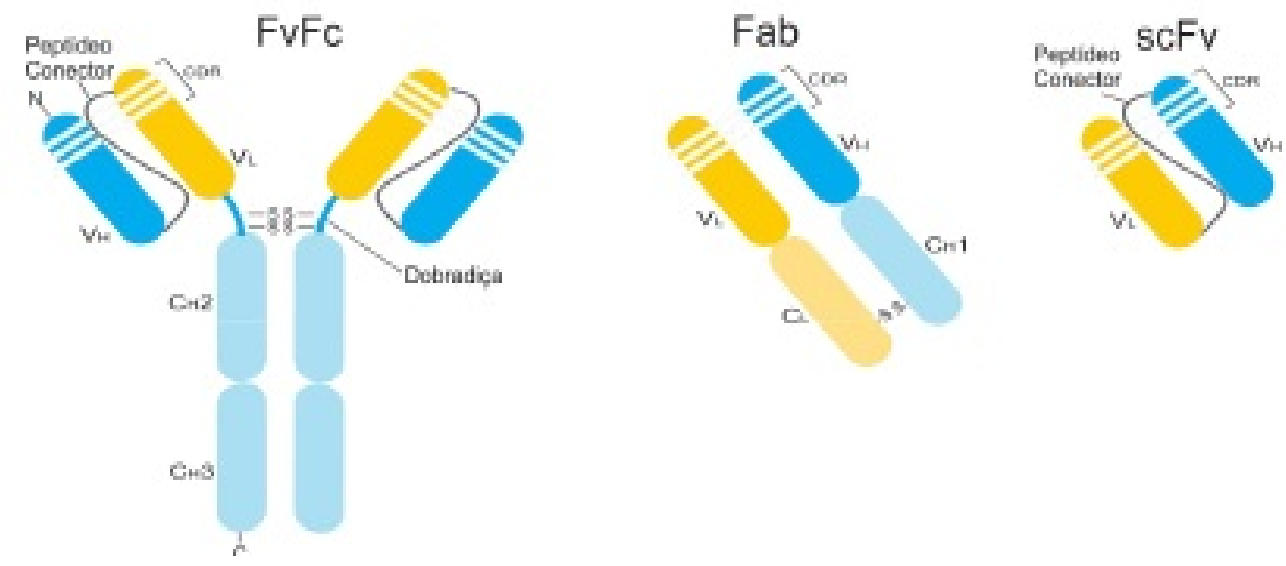

Figura 3: Nomenclatura de anticorpos recombinantes obtidos por engenharia genética. Imunoglobulina nativa IgG e derivadas. Siglas: VH, variável pesada; VL, variável leve; CL, constante leve; $\mathrm{CH}$, constante pesada; Fv, fragmento variável; Fc fragmento cristalizável, Fab, fragmento de ligação ao antígeno; dHlx hélices anfipáticas para dimerização dos fragmentos scFv. Em roxo encontram-se os linkers peptídicos artificiais(Schirrmann et al., 2008) . 


\subsection{Anticorpos Monoclonais}

A produção de anticorpos monoclonais é uma tecnologia criada e estabelecida em 1975 por George Kõhler e César Milstein. Essa tecnologia tem por objetivo a geração de uma linha celular estável que gera um isótipos de imunoglobulina específica contra um antígeno específico, que resulta na fusão de duas células diferente por meios físicos e químicos (polietileno glicol-centrifugação).

A primeira célula envolvida é um linfócito $B$ de um animal previamente imunizado com o antígeno de interesse, o qual fornece a memória imune e a capacidade de produzir anticorpos específicos para o antígeno. A segunda é uma célula de tumor de anticorpos de mieloma não-secretoras de anticorpos e deficiente na enzima hipoxantina-guaninafosforribosil-transferase (HGPRT), útil no processo de seleção subsequente de hibridomas, que fornece capacidade ilimitada de divisão (imortalidade), desta união surge uma célula imortal com capacidade praticamente ilimitada para a produção de anticorpos monoclonais, chamada de hibridoma (Köhler and Shulman, 1979). A hibridação de células somáticas tem duas características muito importantes: 1) é um dos métodos básicos da produção de anticorpos monoclonais para um determinante antigênico conhecido, e 2) podem ser usados para identificar antígenos desconhecidos presentes numa mistura, levando em consideração que cada hibridoma é específico para um determinante antígeno

Os anticorpos monoclonais (mAbs) são ferramentas essenciais na área clínica e biotecnológica, e provaram ser úteis no diagnóstico e tratamento de doenças infecciosas, imunológicas e neoplásicas e também no estudo de interações patógeno-hospedeiro além da marcação, detecção e quantificação de várias moléculas.

A geração de anticorpos monoclonais é uma das áreas de mais rápido crescimento na indústria biotecnológica e farmacêutica. O grande investimento em anticorpos de uso clínico gerou uma ampla variedade de moléculas modificadas com o propósito tanto de direcionar especificamente sua ação, quanto de minimizar seus efeitos colaterais. Graças às inovações tecnológicas e ao desenvolvimento de anticorpos modificados para uso terapêutico, a indústria farmacêutica é um das áreas de maior crescimento. (Cohen and Wilson, 2009). Na atualidade existem mais de quarenta anticorpos monoclonais que foram aprovados pela Food 
and Drug Administration (FDA) dos Estados Unidos para uso terapêutico em humanos. (Tabela 1).

Tabela 1. Anticorpos monoclonais aprovados pelo FDA até 2015. Adaptada do site da Food Drug Administration

\begin{tabular}{|c|c|c|c|c|c|}
\hline Anticorpo & Molécula & Tipo & Indicação & Empresa & Ano de \\
alvo & & & & & \\
aprovação
\end{tabular}




\begin{tabular}{|c|c|c|c|c|c|}
\hline Anticorpo & $\begin{array}{c}\text { Molécula } \\
\text { Alvo }\end{array}$ & Tipo & Indicação & Empresa & $\begin{array}{c}\text { Ano de } \\
\text { aprovação }\end{array}$ \\
\hline $\begin{array}{l}\text { Remicade } \\
\text { (Infliximab) }\end{array}$ & TNF- $\alpha$ & Quimérico & $\begin{array}{c}\text { Artrite } \\
\text { reumatóide } \\
\text { e doença de } \\
\text { Crohn }\end{array}$ & Centocor & 1998 \\
\hline $\begin{array}{c}\text { Herceptin } \\
\text { (Trastuzumab) }\end{array}$ & Her2/neu & Humanizado & $\begin{array}{c}\text { Metástase } \\
\text { de câncer de } \\
\text { mama }\end{array}$ & Genentech & 1998 \\
\hline $\begin{array}{c}\text { Mylotarg } \\
\text { (Gemtuzumab) }\end{array}$ & CD33 & Humanizado & $\begin{array}{l}\text { Leucemia } \\
\text { mielóide }\end{array}$ & Wyeth & 2000 \\
\hline $\begin{array}{c}\text { Campath } \\
\text { (Alemtuzumab) }\end{array}$ & CD52 & Humanizado & $\begin{array}{l}\text { Leucemia } \\
\text { linfocítica }\end{array}$ & $\begin{array}{l}\text { Millenniu } \\
\mathrm{m} / \\
\text { ILEX }\end{array}$ & 2001 \\
\hline $\begin{array}{c}\text { Zevalin } \\
\text { (Ibritumomab) }\end{array}$ & CD20 & Murino & $\begin{array}{c}\text { Linfoma } \\
\text { Non- } \\
\text { Hodgkins }\end{array}$ & $\begin{array}{l}\text { Biogen } \\
\text { IDEC }\end{array}$ & 2002 \\
\hline $\begin{array}{c}\text { Humira } \\
\text { (Adalimumab) }\end{array}$ & TNF- $\alpha$ & Humano & $\begin{array}{c}\text { Artrite } \\
\text { reumatóide, } \\
\text { doença de } \\
\text { Crohn }\end{array}$ & Abbott & 2002 \\
\hline $\begin{array}{c}\text { Xolair } \\
\text { (Orlalizumab) }\end{array}$ & $\operatorname{IgE}$ & Humanizado & Asma & Genentech & 2003 \\
\hline
\end{tabular}




\begin{tabular}{|c|c|c|c|c|c|}
\hline Anticorpo & $\begin{array}{c}\text { Molécula } \\
\text { Alvo }\end{array}$ & Tipo & Indicação & Empresa & $\begin{array}{c}\text { Ano de } \\
\text { aprovação }\end{array}$ \\
\hline $\begin{array}{c}\text { Bexxar } \\
\text { (Tositumomab- } \\
\text { I131) }\end{array}$ & CD20 & Murino & $\begin{array}{c}\text { Linfoma } \\
\text { Non- } \\
\text { Hodgkins }\end{array}$ & Corixa & 2003 \\
\hline $\begin{array}{c}\text { Raptiva } \\
\text { (Efalizumab) }\end{array}$ & CD11a & Humanizado & Psoríase & Genentech & 2003 \\
\hline $\begin{array}{c}\text { Erbitux } \\
\text { (Cetuximab) }\end{array}$ & EGFR & Quimérico & $\begin{array}{l}\text { Câncer } \\
\text { coloretal }\end{array}$ & $\begin{array}{l}\text { Imclone } \\
\text { Systems }\end{array}$ & 2004 \\
\hline $\begin{array}{c}\text { Avastin } \\
\text { (Bevacizumab) }\end{array}$ & VEGF & Humanizado & $\begin{array}{c}\text { Câncer } \\
\text { coloretal, } \\
\text { renal }\end{array}$ & Genentech & 2004 \\
\hline $\begin{array}{c}\text { Tysabri } \\
\text { (Natalizumab) }\end{array}$ & $\begin{array}{c}\text { Integrina } \\
\text { A4 }\end{array}$ & Humanizado & $\begin{array}{l}\text { Doença de } \\
\text { crohn, } \\
\text { esclerose }\end{array}$ & $\begin{array}{l}\text { Biogen } \\
\text { IDEC }\end{array}$ & 2004 \\
\hline $\begin{array}{c}\text { Lucentis } \\
\text { (Renibizumab) }\end{array}$ & VEGF-A & Humanizado & $\begin{array}{c}\text { Degeneraçã } \\
\text { o macular }\end{array}$ & Genentech & 2006 \\
\hline $\begin{array}{c}\text { Vectibix } \\
\text { (Panitumomab) }\end{array}$ & EGFR & Humano & $\begin{array}{l}\text { Câncer } \\
\text { coloretal }\end{array}$ & Amgen & 2006 \\
\hline $\begin{array}{c}\text { Soliris } \\
\text { (Eculizumab) }\end{array}$ & $\mathrm{C} 5$ & Humanizado & $\begin{array}{l}\text { Hemoglobin } \\
\text { úria }(\mathrm{PNH})\end{array}$ & $\begin{array}{l}\text { Alexion } \\
\text { Pharm }\end{array}$ & 2007 \\
\hline Milatuzumab & CD74 & Humanizado & $\begin{array}{l}\text { Mieloma } \\
\text { múltiplo, }\end{array}$ & $\begin{array}{l}\text { Immunom } \\
\text { edics }\end{array}$ & 2008 \\
\hline
\end{tabular}




\begin{tabular}{|c|c|c|c|c|c|}
\hline Anticorpo & $\begin{array}{c}\text { Molécula } \\
\text { Alvo }\end{array}$ & Tipo & Indicação & Empresa & $\begin{array}{c}\text { Ano de } \\
\text { aprovação }\end{array}$ \\
\hline & & & $\begin{array}{l}\text { Linfoma } \\
\text { Non- } \\
\text { Hodgkin }\end{array}$ & & \\
\hline $\begin{array}{c}\text { Cimzia } \\
\text { (Certolizumab) }\end{array}$ & Integrina & Humanizado & $\begin{array}{c}\text { Doença de } \\
\text { Crohn }\end{array}$ & $\begin{array}{l}\text { Biogen } \\
\text { IDEC }\end{array}$ & 2008 \\
\hline $\begin{array}{c}\text { Simponi } \\
\text { (Golimumab) }\end{array}$ & TNF- $\alpha$ & Humano & $\begin{array}{l}\text { Artrite } \\
\text { reumatoide }\end{array}$ & $\begin{array}{c}\text { Johnson } \\
\& \\
\text { Johnson }\end{array}$ & 2009 \\
\hline $\begin{array}{c}\text { Ilaris } \\
\text { (Canakinumab) }\end{array}$ & IL-1 $\beta$ & Humano & CAPS & Novartis & 2009 \\
\hline $\begin{array}{c}\text { Stelara } \\
\text { (Ustekinumab) }\end{array}$ & $\begin{array}{l}\text { IL-12 e } \\
\text { IL-23 }\end{array}$ & Humano & Psoríase & $\begin{array}{c}\text { Johnson } \\
\& \\
\text { Johnson }\end{array}$ & 2009 \\
\hline $\begin{array}{c}\text { Arzerra } \\
\text { (Ofatumumab) }\end{array}$ & CD20 & Humano & $\begin{array}{c}\text { Leucemia } \\
\text { linfocítica } \\
\text { crônica }\end{array}$ & Genmab & 2010 \\
\hline $\begin{array}{c}\text { Vedotin } \\
\text { (Brentuximab) }\end{array}$ & CD30 & Quimérico & $\begin{array}{l}\text { Linfoma } \\
\text { Hodgkin }\end{array}$ & $\begin{array}{c}\text { Seatle } \\
\text { Genetics }\end{array}$ & 2011 \\
\hline $\begin{array}{c}\text { Ipi } \\
\text { (Ipilimumab) }\end{array}$ & CTLA-4 & Humano & $\begin{array}{l}\text { Melanoma } \\
\text { metastático }\end{array}$ & Bristol & 2011 \\
\hline
\end{tabular}




\begin{tabular}{|c|c|c|c|c|c|}
\hline Anticorpo & $\begin{array}{c}\text { Molécula } \\
\text { Alvo }\end{array}$ & Tipo & Indicação & Empresa & $\begin{array}{c}\text { Ano de } \\
\text { aprovação }\end{array}$ \\
\hline $\begin{array}{l}\text { Belimumab } \\
\text { (Benlysta) }\end{array}$ & BLyS & $\begin{array}{c}\text { Humano } \\
\text { IgG1 }\end{array}$ & $\begin{array}{c}\text { Lúpus } \\
\text { Eritematoso } \\
\text { Sistêmico }\end{array}$ & $\begin{array}{l}\text { Human } \\
\text { Genome } \\
\text { Sciences }\end{array}$ & 2011 \\
\hline $\begin{array}{c}\text { Brentuximab } \\
\text { vendontin } \\
\text { (Adcetris) }\end{array}$ & CD30 & $\begin{array}{l}\text { Quimérico } \\
\text { IgG1; } \\
\text { imunoconjug } \\
\text { ado }\end{array}$ & $\begin{array}{l}\text { Linfoma de } \\
\text { Hodgkin, } \\
\text { Linfoma de } \\
\text { grandes } \\
\text { células } \\
\text { anaplásicas } \\
\text { sistêmicas }\end{array}$ & $\begin{array}{c}\text { Seatle } \\
\text { Genetics }\end{array}$ & 2011 \\
\hline $\begin{array}{c}\text { Pertuzumab } \\
\text { (Perjeta) }\end{array}$ & HER2 & $\begin{array}{c}\text { Humanizado } \\
\text { IgG1 }\end{array}$ & $\begin{array}{c}\text { Cancer de } \\
\text { mama }\end{array}$ & Genentech & 2012 \\
\hline $\begin{array}{c}\text { Raxibacumab } \\
\text { (Pending) }\end{array}$ & $\begin{array}{c}\text { B } \\
\text { anthrasis } \\
\text { PA }\end{array}$ & $\begin{array}{c}\text { Humano } \\
\text { IgG1 }\end{array}$ & $\begin{array}{c}\text { Infecção } \\
\text { Antrax }\end{array}$ & $\begin{array}{l}\text { Human } \\
\text { Genome } \\
\text { ieScnces }\end{array}$ & 2012 \\
\hline $\begin{array}{c}\text { Ado- } \\
\text { trastuzumab } \\
\text { entansine } \\
\text { (Kadcyla) }\end{array}$ & HER2 & $\begin{array}{l}\text { Humanizado } \\
\text { IgG1 } \\
\text { imunoconjug } \\
\text { ado }\end{array}$ & $\begin{array}{c}\text { Câncer de } \\
\text { mama }\end{array}$ & $\begin{array}{c}\text { Genentech } \\
\text { / Roche }\end{array}$ & 2013 \\
\hline
\end{tabular}




\begin{tabular}{|c|c|c|c|c|c|}
\hline Anticorpo & $\begin{array}{c}\text { Molécula } \\
\text { Alvo }\end{array}$ & Tipo & Indicação & Empresa & $\begin{array}{c}\text { Ano de } \\
\text { aprovação }\end{array}$ \\
\hline $\begin{array}{c}\text { Obinutuzumab } \\
\text { (Gazyva) }\end{array}$ & CD20 & $\begin{array}{l}\text { Humanizado } \\
\qquad \operatorname{IgG} 1\end{array}$ & $\begin{array}{c}\text { Leucemia } \\
\text { Linfocítica } \\
\text { Crônica }\end{array}$ & Roche & 2013 \\
\hline $\begin{array}{c}\text { Siltuximab } \\
\text { (Sylvant) }\end{array}$ & IL-6 & $\begin{array}{l}\text { Quimérico } \\
\text { IgG1 }\end{array}$ & $\begin{array}{l}\text { Doença de } \\
\text { Castleman }\end{array}$ & $\begin{array}{l}\text { Janssen } \\
\text { Biotech }\end{array}$ & 2014 \\
\hline $\begin{array}{c}\text { Vedolizumab } \\
\text { (Entyvio) }\end{array}$ & $\begin{array}{c}\alpha 4 \beta 7 \\
\text { integrina }\end{array}$ & $\begin{array}{l}\text { Humanizado } \\
\qquad \text { IgG1 }\end{array}$ & $\begin{array}{c}\text { Colite } \\
\text { ulcerativa e } \\
\text { Doença de } \\
\text { Crohn }\end{array}$ & $\begin{array}{c}\text { Millenniu } \\
\text { m } \\
\text { Pharmace } \\
\text { uticals/ } \\
\text { Takeda }\end{array}$ & 2014 \\
\hline $\begin{array}{c}\text { Ramucirumab } \\
\text { (Cyramza) }\end{array}$ & VEGFR2 & $\begin{array}{c}\text { Humano } \\
\text { IgG1 }\end{array}$ & $\begin{array}{l}\text { Câncer } \\
\text { Gástrico }\end{array}$ & $\begin{array}{l}\text { ImClone } \\
\text { Systems }\end{array}$ & 2014 \\
\hline $\begin{array}{c}\text { BLINCYTO } \\
\text { (BLINATOMO } \\
\text { MABE) }\end{array}$ & $\begin{array}{l}\text { CD19 e } \\
\text { CD3 }\end{array}$ & $\begin{array}{l}\quad \text { Murino } \\
(\mathrm{scFv} \\
\text { biespecífico) }\end{array}$ & $\begin{array}{l}\text { Leucemia } \\
\text { Linfoblástic } \\
\text { a Aguda }\end{array}$ & Amgen & 2014 \\
\hline $\begin{array}{c}\text { OPDIVO } \\
\text { (NIVOLUMABE } \\
\text { ) }\end{array}$ & PD1 & Humano & $\begin{array}{c}\text { Câncer de } \\
\text { Pulmão }\end{array}$ & $\begin{array}{l}\text { Bristol- } \\
\text { Myers } \\
\text { Squibb }\end{array}$ & 2014 \\
\hline $\begin{array}{c}\text { COSENTYX } \\
\text { SECUKINUMA } \\
\text { BE }\end{array}$ & IL-17a & Humano & Psoríase & Novartis & 2015 \\
\hline
\end{tabular}




\begin{tabular}{|c|c|c|c|c|c|}
\hline Anticorpo & $\begin{array}{c}\text { Molécula } \\
\text { Alvo }\end{array}$ & Tipo & Indicação & Empresa & $\begin{array}{c}\text { Ano de } \\
\text { aprovação }\end{array}$ \\
\hline $\begin{array}{c}\text { UNITUXIN } \\
\text { DINOTUXIMA }\end{array}$ & GD2 & Quimérico & Neuroblasto & Silver & 2015 \\
BE & & & $\mathrm{m}$ & Spring & \\
\hline
\end{tabular}

Desde que, o primeiro anticorpo monoclonal foi produzido por tecnologia de hibridoma para uso clínico em pacientes com a rejeição primária a transplante, observou-se que estes anticorpos monoclonais, sendo de origem murino, geravam uma forte resposta imune de hiper-responsividade em $80 \%$ dos pacientes, a chamada resposta HAMA (Human Anti-Mouse Antibody) (Holliger and Hudson, 2005; Hwang and Foote, 2005). Consistente com isto, tem sido desenvolvido diferentes técnicas para minimizar essa resposta e com melhor ação efetora (Beerli and Rader, 2010). Atualmente, a incorporação das técnicas de biologia molecular e da engenharia genética tem permitido a expansão e a geração de anticorpos monoclonais e seus usos, desenvolvendo-se técnicas como a hibridização, a quimerização, a humanização e a produção de anticorpos monoclonais totalmente humano. Igualmente tem possibilitado o desenvolvimento de métodos in vitro para gerar anticorpos monoclonais em bactérias por transgênese, com as sequências de interesse.

\subsection{Engenharia de Anticorpos}

A estratégia inicial utilizada para reduzir a resposta imune humoral, HAMA foi a produção dos mAbs quiméricos. Um mAb quimérico é uma molécula artificial que tem as cadeias pesada e leve derivadas de uma Ig humana e as regiões variáveis VH e VL são obtidas a partir de um mAb murino (Figura 4). O objetivo com a construção de um mAb quimérico é reduzir a imunogenicidade em humanos, mas sem afetar a especificidade de mAb. Sabe-se que a porção mais imunogênica da molécula de Ig está ligada à porção constante da molécula, em particular, a região Fc (Marszal and Fowler, 2012).

A técnica de "Quimerização" foi desenvolvida por Morrison et al. e Boulliane em 1985. O procedimento envolvia a clonagem dos genes VH e VL murinos e a inserção desses genes clonados em vetores de expressão eucariotos aos quais foram previamente 
incorporados genes que codificam a porção constante de cadeias pesadas e leves humanas. Finalmente estes vetores são estavelmente transfetados para uma linha celular selecionada. A clonagem dos genes de VH e VL é feita por RT-PCR (Figura 4) utilizando como molde RNA total ou RNA mensageiro (RNAm) obtido a partir de um hibridoma do qual se obtém os genes codificadores das cadeias VH e VL com a especificidade de interesse e os oligonucleótideos complementares às extremidades 3 'e 5 ' de cada gene como iniciadores. Atualmente estão disponíveis famílias de oligonucleótideos para a clonagem de VH e VL murinos, humanos e outros genes de outras espécies. Estas famílias são capazes de amplificar a maioria, se não todos, os genes funcionais destas espécies e, geralmente, conter locais de reconhecimento de enzimas de restrição que facilitam a identificação, manipulação e inserção nos vetores de expressão dos genes amplificados por PCR (Morrison et al., 1984).

$\mathrm{Na}$ atualidade se encontram disponíveis uma série de vetores de tipo "cassete" onde os genes podem ser facilmente clonados no contexto de qualquer isótipo de cadeia leve humana ou pesada ((Morrison et al., 1984) Da mesma forma, os avanços no campo da tecnologia de transferência de genes têm também facilitado e tornado mais eficiente, o processo de inserção de DNA estranho em diferentes linhas celulares eucariotas.

Foi demonstrado que os anticorpos quimérico são capazes de reconhecer, ligar o antígeno e mediar funções efetoras, tais como a ativação do complemento e reconhecimento dos receptores Fc (Morrison et al., 1984) de forma eficiente. Além disso, quando se compara o anticorpo quimérico com o anticorpo monoclonal equivalente, observa-se uma redução na imunogenicidade (LoBuglio et al., 1989). A partir daí, anticorpos quimérico com uma grande variedade de especificidades foram desenvolvidos. Alguns exemplos de sucesso no campo clínico são: os produtos ou abciximab - desenvolvido pelas empresas Centocor e Eli Lilly; IDEC-CD28 ou rituximabe - desenvolvido por IDEC Pharmaceuticals e Genentech; infliximab - desenvolvido pela Centocor; e o fragmento Fab de um anticorpos quimérico murinho-humano (Cohen and Wilson, 2009) entre outros.

Uma das limitações apresentadas na quimerização de anticorpos monoclonais é a baixa frequência de transformantes que produzem o anticorpo quimérico. Embora, os anticorpos monoclonais quiméricos sejam menos imunogênicos do que os anticorpos monoclonais de camundongo, houve respostas significativas de anticorpos do tipo anticorpo- 
antiquiméricos em $40 \%$ dos pacientes, conhecida como resposta HACA (Human AntiChimeric Antibody) (Hwang and Foote, 2005; Shuptrine et al., 2012).

A construção de anticorpos monoclonais humanizados ocorre por engenharia de proteínas. Neste processo, os CDR das IgG de origem murino são transferidos para as estruturas das regiões variáveis das cadeias pesada ou leve de uma Ig de origem de uma espécie diferente, neste caso, humano (Caldas et al., 2000; Shuptrine et al., 2012).

Foi assim que em 1986, incorporou-se a técnica de humanização de anticorpos com o objetivo de minimizar os componentes do anticorpo de origem murino geradores da resposta imune. Esta tecnologia foi desenvolvida pouco tempo depois da invenção da mAbs quiméricos e, no presente, é constituída por um conjunto de procedimentos (AGUILLON GUTIERREZ, 2014; Shuptrine et al., 2012) tais como “CDR grafting” (transplante de CDR), "Ac reshaping" e "Ac resurfacing/veneering". A técnica se baseia na suposição de que o sítio de combinação ao antígeno, o parátopo, forma-se a partir da combinação espacial das asas hipervariáveis que correspondem às CDRs, enquanto as regiões de arcabouço funcionam apenas como um andaime cuja única função é servir de suporte estrutural ao parátopo. Partindo deste princípio, na elaboração de um mAb Humano, as CDR de um anticorpo murino são transplantadas nas regiões de arcabouço humanas (Figura 4) formando-se assim uma região variável híbrida murino-humano e conferindo a especialidade desejada a uma molécula que no restante de sua estrutura é completamente humana. A vantagem é que os epítopos associados às regiões de arcabouço murinas, nas quais estão presentes os mAb quimérico não se encontram nos mAb Humano. (AGUILLON GUTIERREZ, 2014; Caldas et al., 2000; Presta, 2006; Shuptrine et al., 2012). 


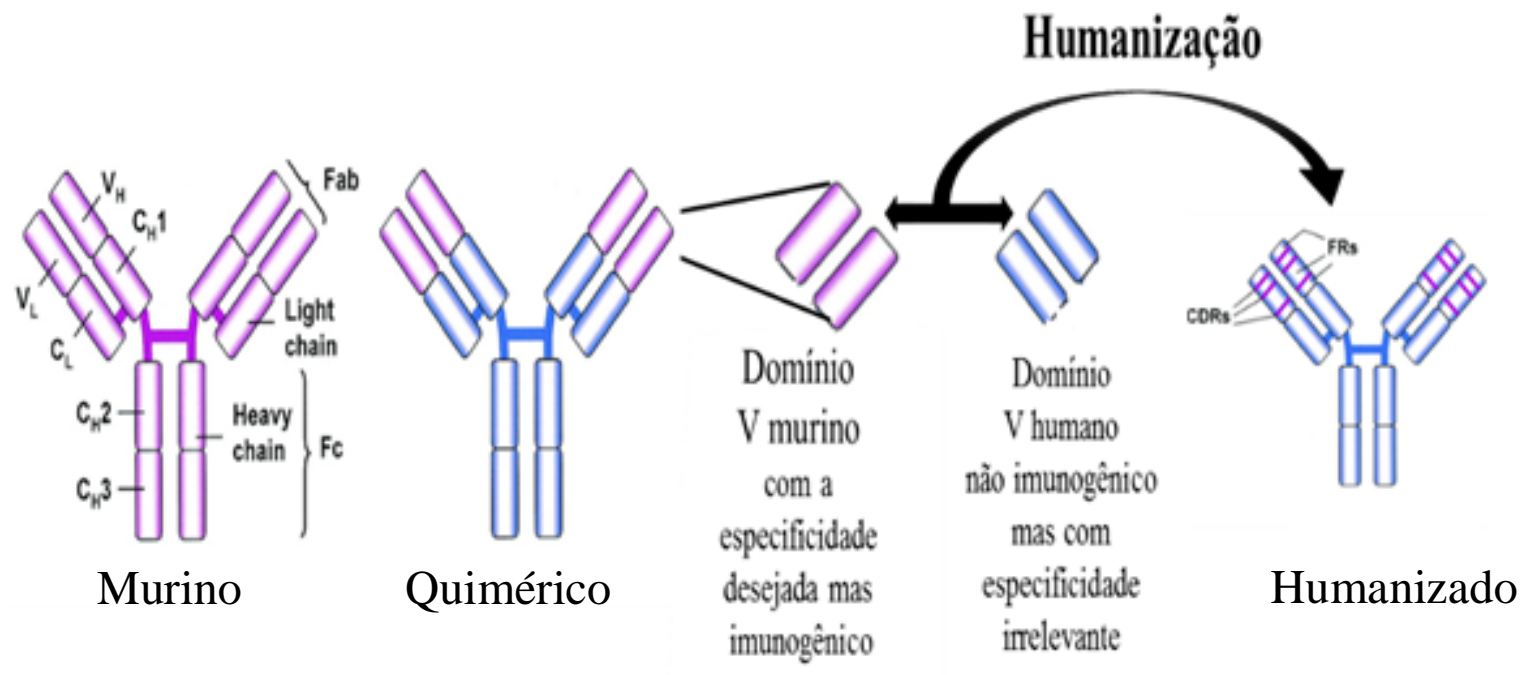

Figura 4: Representação esquemática de anticorpos quiméricos e humanizados. Anticorpos quiméricos mantêm os domínios $\mathrm{V}$ inteiros do anticorpo murino e as porções constantes humanas, enquanto o anticorpo humanizado conserva apenas as regiões determinantes de complementaridade (CDRs) do anticorpo murino em um arcabouço humano.

Para produzir um mAb humanizado é necessário conhecer toda a sequência dos domínios variáveis murinos e a localização das sequências de DNA que correspondem às 3 CDRs murinos. Esta informação é utilizada para desenhar e criar genes sintéticos nos quais as CDRs murinas são combinadas com regiões de arcabouço humanas selecionadas cuidadosamente com base na sua similaridade com as regiões correspondentes as de arcabouço murinas. Em seguida os genes "humanizados" são inseridos em vetores de expressão adequados que contém o restante da informação estrutural necessária para a síntese de uma cadeia lg humana leve ou pesada.(AGUILLON GUTIERREZ, 2014).

Existem dois aspectos que poderiam ser considerados como desvantagem na produção de um mAb humanizado. Em primeiro lugar, a manipulação das CDR murinas e sua inserção no contexto de regiões de arcabouço humanas geralmente leva a uma diminuição da afinidade do mAb (Buss et al., 2012). Isto é devido ao fato das regiões de arcabouço não serem apenas andaimes, elas desempenham um papel decisivo no arranjo tridimensional das CDR. Além disso, em alguns casos mostrou-se que certos resíduos de aminoácido das regiões de arcabouço participam diretamente na combinação com o epítopo (Presta, 2006). O outro aspecto está relacionado com a complexidade da técnica. Enquanto o procedimento para produzir um mAb quimérico é relativamente rápido, a produção de um mAb humanizado é 
comparativamente mais cuidadosa, necessitando de um tempo considerável e é um processo no qual a manutenção da afinidade depende, em último caso, do ensaio e erro (Merino, 2011). Assim, o principal objetivo na produção de mAb humanizado é eliminar a imunogenicidade do anticorpo murino nem sempre é alcançado.

O desenvolvimento de anticorpos com fins terapêuticos tem crescido de maneira significativa na última década. Inicialmente foram utilizados anticorpos de origem murino, embora estas moléculas tenham o inconveniente de gerar uma resposta imune a elas. Os anticorpos murinos podem transformar-se em moléculas "humanizadas", de maneira que não são reconhecidos pelo sistema imunológico. Os anticorpos humanizados também são caracterizados por uma meia-vida mais longa demorando mais tempo a induzir resistência à terapia e provocar uma resposta conhecida como resposta HAHA ( Human Anti-Humanized Antibody), em apenas 9\% dos pacientes (Hwang and Foote, 2005). Isso porque aparentemente há epítopos associados com o idiotipo do anticorpo.

Recentemente foram desenvolvidas estruturas com capacidade para reconhecer múltiplos antígenos, com diferentes tamanhos e propriedades. Juntamente com o aumento de identificação de alvos terapêuticos, a utilização de anticorpos, tanto "nu" como conjugados com toxinas, farmacêuticos e compostos radioativos, tem aumentado significativamente. Os anticorpos utilizados com maior frequência no tratamento contra o câncer são as imunoglobulinas $\mathrm{G}(\operatorname{lgG})$. Os avanços no campo da genética humana e molecular permitiram a síntese de fragmentos de $\operatorname{lgG}$. Estes anticorpos modificados são caracterizados por apresentar afinidade antigénica diferente, um número variável de sítios de união ao antígeno e diferentes propriedades farmacológicas.

As mais utilizadas são os fragmentos variáveis de cadeia única ( $\mathrm{scFv}$ ) do inglês single chain Fv) (Grigorenko et al., 2015), que são compostos por cadeias variáveis pesadas e leves unidos por um peptídeo. Estas moléculas possuem um peso molecular de $\approx 25 \mathrm{kDa}$ e são eficazes como veículos de radionucleótidos. Também foram desenvolvidas estruturas de maior tamanho, como os chamados diabodis e minibodis, com o peso molecular mais baixo estas estruturas facilitam sua excreção renal e sua especificidade no local do tumor, enquanto se mostra menor toxidade das $\lg G$ completas. 
Várias técnicas permitem a geração de anticorpos monoclonais totalmente humanos, ideais por terem pouco risco de apresentarem algum tipo de resposta no paciente. Estes podem ser obtidos por três técnicas principais, como: a expressão e seleção de fragmentos de $\lg$ com as frações variáveis de cadeia única, Fab e $\mathrm{ScFv}$, em bactérias, graças às bibliotecas de bacteriófagos por phage display (Figura 5) ; a utilização de camundongos transgênicos, que já produzem anticorpos humanos; e também por meio da imortalização de células B humanas, produtoras de anticorpo, com infecção viral que foram inseridos dentro de seu DNA tais genes (Rader, 2012).

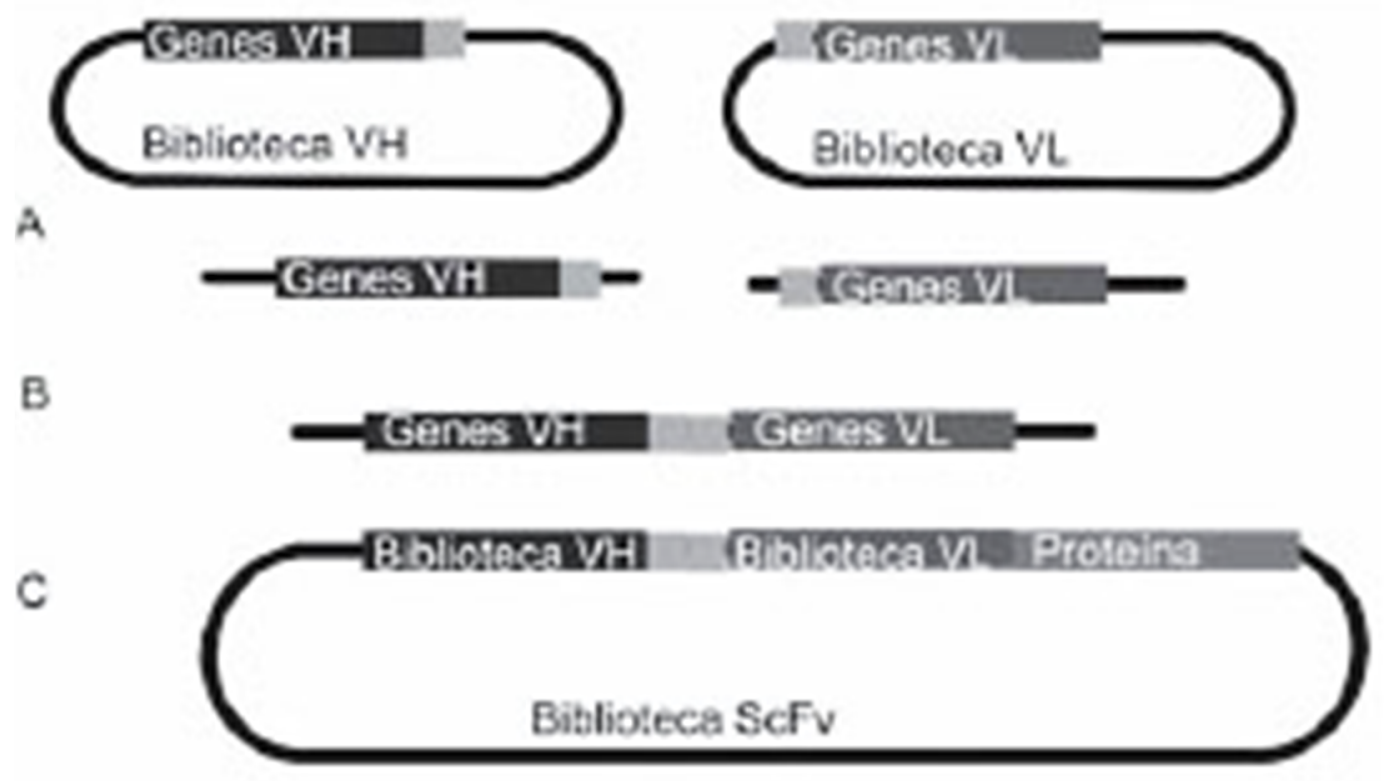

Figura 5.Construção de uma biblioteca de fagos para geração de anticorpos monoclonais: A : são geradas bibliotecas dos genes das regiões variáveis das cadeias pesadas e leves a partir de um repertório de células B que não foram recrutadas pelo sistema imunológico por meio de técnicas de biologia molecular, como o PRC, utilizando iniciadores não específicos. B: estas sequências são cortadas por meio de enzimas de restrição e unidas por meio de PRC resultando um repertório de sequências de genes que codificam frações variáveis de cadeia simples $(\mathrm{ScFv})$. C:estes genes de $\mathrm{ScFv}$ unem-se à sequência genética de um bacteriófago para ser expressados junto com uma proteína de superfície para, em seguida, fazer a seleção dos bacteriófagos que apresentem maior afinidade pelo antígeno para estudar e, em seguida, transfectadas a bactérias para amplificar e produzir as ScFv.

Atualmente, a tecnologia com fagos filamentosos é uma das mais utilizadas e bem estabelecidas para o desenvolvimento de novos anticorpos monoclonais humanos. A construção de anticorpos monoclonais recombinantes mediante a tecnologia de bibliotecas de fagos com genes, que codificam as regiões variáveis de $\mathrm{lg}$, tem-se mostrado útil na investigação básica e em usos clínicos. Sendo uma das melhores estratégias estabelecidas e 
otimizada (Thie et al., 2008). As regiões ScFv são as candidatas usadas nesta tecnologia por conter os domínios de união antigênica das lg. Estas construções de bibliotecas de genes fornecem, então, alguns repertórios de anticorpos com alta afinidade para um amplo número de antígenos, no qual está determinado pelo tamanho da biblioteca e alcança medidas de 6,7 x $10^{9}$ (da Silva et al., 2008; Kim et al., 2005; Rader, 2012). Outra maneira de selecionar anticorpos por phage display contra antígenos de interesse é fazendo uma seleção guiada. Desta maneira podem se obter fragmentos de anticorpos na forma de $\mathrm{scFv}$ com sequencia totalmente humanos, anticorpos hemi-humanos e totalmente humano, a partir de bibliotecas apresentadas em fagos onde os genes codificadores dos domínios VH e VL de um scFv ligante são trocados por um repertório de genes codificadores destes domínios variáveis $\mathrm{V}$ (da Silva et al., 2008; Dall' Acqua et al., 2005; Kim et al., 2005; Rader, 2012). Nesta técnica, um dos domínios, por exemplo, o VL é mantido, enquanto o outro, codificando o VH, é trocado por uma série de variações dele, em seguida é feita a seleção contra determinado antígeno, para se obter o fragmento scFv (VH e VL) com a maior afinidade. (Chain shuffling.) (Figura ) (da Silva et al., 2008; Dall' Acqua et al., 2005; Thie et al., 2008).
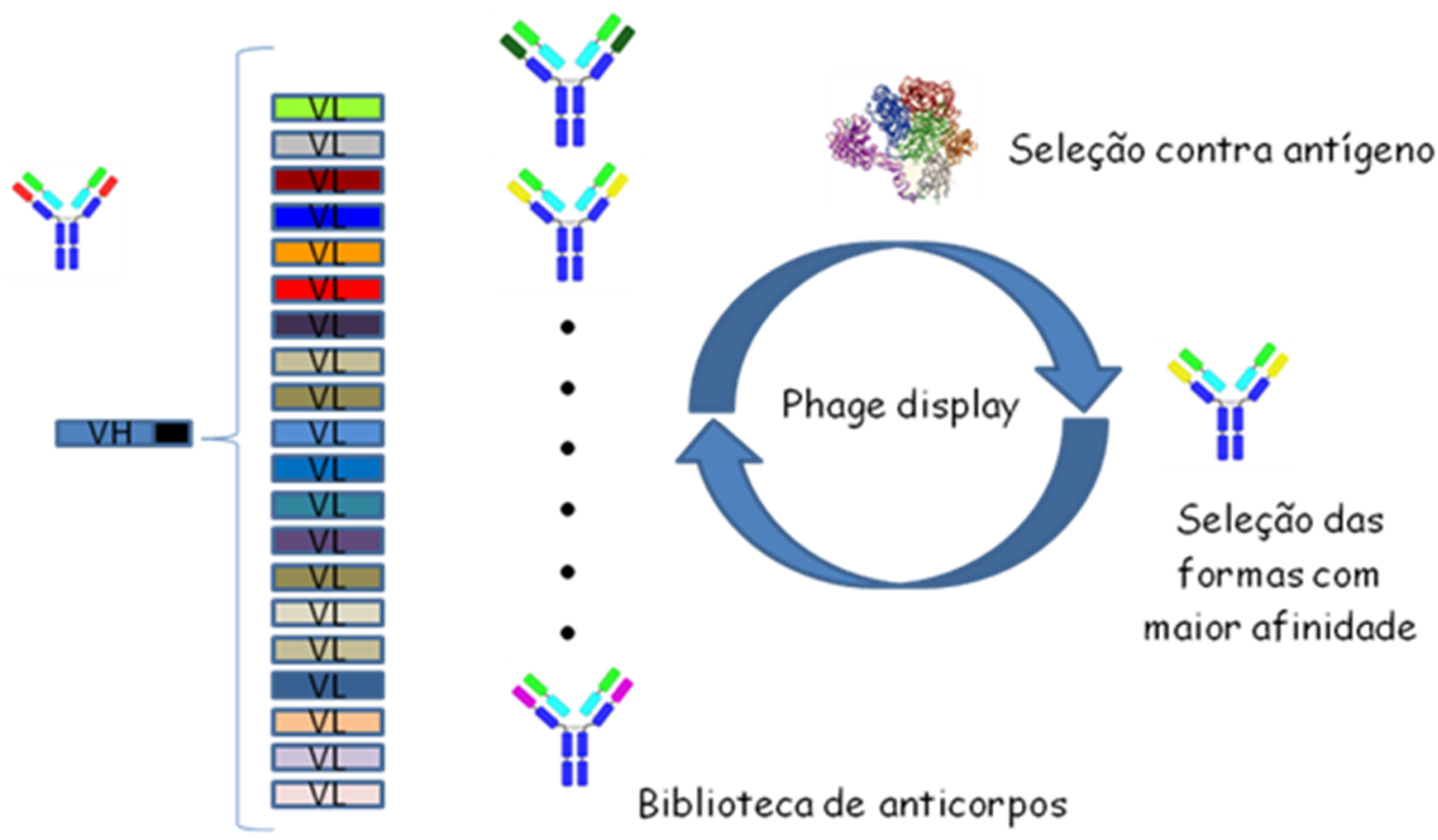

Figura 6: Representação esquemática da seleção guiada usando-se a técnica de chain shuffling. A partir de um domínio VH sabidamente ligante ao antígeno de interesse e de uma biblioteca de VLs humanos é feita a seleção guiada de VLs humanos com afinidade pelo antígeno. Posteriormente um ou mais VLs humanos escolhidos podem ser usados para a seleção de VHs humano com maior afinidade pelo antígeno de interesse, a partir de uma biblioteca de VHs humanos. 


\subsection{O antígeno CD20 e os anticorpos anti-CD20}

O CD20 humano é uma molécula de superfície expressa exclusivamente em células $\mathrm{B}$, desde o seu estágio pré-B até o estágio de célula $\mathrm{B}$ madura periférica não sendo expresso em condições normais em plasmocitos (A expressão do CD20 é de aproximadamente 100.000 moléculas/célula, em células B normais, e não se encontram quantidades significativas dessa molécula solúvel no soro ou em outros tipos celulares (Figura 6) (Ginaldiet al., 1998).

Em células B malignas, como acontece com as células B do Linfoma non-Hodgkin (NHL), da Leucemia linfocítica crônica (CLL), do Linfoma Folicular (LF) e Linfoma da Zona Marginal (MZL), o CD20 tem sua expressão aumentada (Du et al., 2007; Maloney, 2012). Devido a essas características o CD20 vem sendo alvo de estudos relacionados ao tratamento de linfomas e algumas doenças autoimunes nas quais são usados anticorpos contra esse antígeno para se obter a depleção das células B (Klein et al., 2012; Pateinakis and Pyrpasopoulou, 2014)

O CD20 humano é uma molécula de superfície que atravessa a membrana plasmática quatro vezes. Apresenta massa molecular variando de 33 a $37 \mathrm{kDa}$. Uma de suas características marcantes é uma volta ("loop") extracelular de aproximadamente 44 aminoácidos (da lisina 142 a Ser 185). Esse loop entre os domínios 3 e 4 transmembrânicos contém uma ponte dissulfeto entre as cisteínas 167-183. A expressão do CD20 é de aproximadamente 100.000 moléculas/célula, em células B normais, e não se encontram quantidades significativas dessa molécula solúvel no soro ou em outros tipos celulares (Figura 6) (Johnson et al., 2009; Maloney, 2012) 


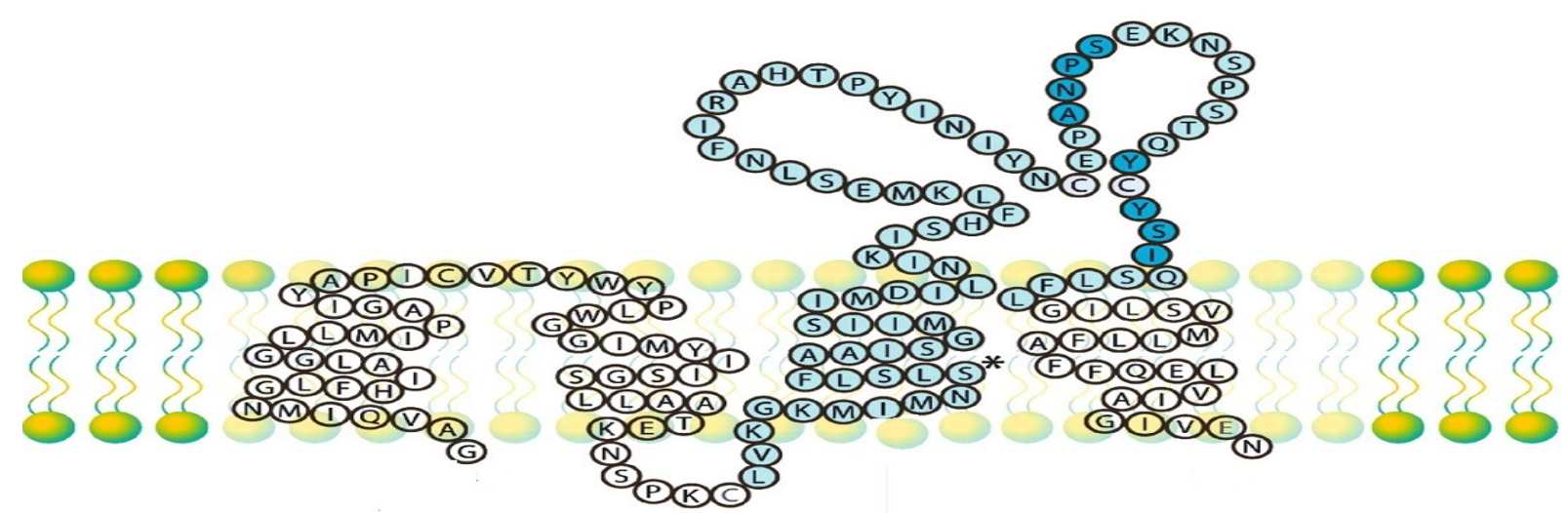

Figura 6.Modelo da molécula de CD 20 humana. Representación de la secuencia de aminoácidos que codifica para la porción trans-membrana de la proteína CD20 (adaptado de Carpeta et al.).

Vários anticorpos anti-CD20 foram descritos desde a década de 1990, tanto murinos como quiméricos, humanizados e humanos. Dentre os diferentes anticorpos desenvolvidos contra o CD20 humano, aquele com maior aplicação terapêutica é o rituximabe ((Alduaij and Illidge, 2011; de Lorenzo-Pinto et al., 2013; Fernández et al., 2015)O rituximabe (Rituxan®, MabThera®) é um anticorpo quimérico, onde os domínios variáveis murinos são fusionados às regiões humanas constantes de $\mathrm{IgG1}$ e $\mathrm{Ck}$, seu uso clínico foi aprovado pela FDA para o tratamento de linfomas non-Hodgkin em 1997, e desde então as publicações envolvendo esse anticorpo cresceram exponencialmente (España et al., 2013)A ligação do rituximabe ao antígeno, aferida na ordem de nanomolar, é dependente da ligação entre as duas cisteínas (Binder et al., 2006). O epítopo desse anticorpo foi mapeado utilizando-se bibliotecas de peptídeos apresentada em fagos. Este se encontra na região do loop extracelular, sendo, aparentemente, descontinuo (Binder et al., 2006; Herter et al., 2013; Johnson et al., 2009).

Os estudos mais recentes relativos aos tratamentos de linfomas de células B visam principalmente compreender a forma de atuação dos anticorpos anti-CD20 na depleção das células malignas e apontam diferentes mecanismos que variam de acordo com o epítopo de ligação do anticorpo no antígeno CD20 (de Lorenzo-Pinto et al., 2013; Fernández et al., 2015).A função efetora dos anticorpos anti-CD20 pode ser mediada por ADCC (citotoxicidade celular dependente de anticorpo), CDC (fixação de complemento), ADCP (fagocitose dependente de anticorpo), indução de apoptose por meio de formação de bolsas lipídicas com aumento do influxo de cálcio e ativação de apoptose, e também por aumento da sensibilidade a drogas.(Beers et al., 2010; Binder et al., 2006; Bologna et al., 2013; de Lorenzo-Pinto et al., 2013; Fang et al., 2011; Fernández et al., 2015; Herter et al., 2013; Klein 
et al., 2012; Mayes et al., 2011; Pievani et al., 2011; Stathis and Ghielmini, 2012; Xu et al., 2013).

O rituximabe já se mostrou bastante eficiente no tratamento de linfoma Non-Hodgkin, e apesar de ser um anticorpo quimérico só causa resposta HACA em 3\% dos pacientes com linfoma. Porém essa resposta é bem maior quando o rituximabe é usado para o tratamento de doenças autoimunes e leva a uma tolerização à terapia (de Lorenzo-Pinto et al., 2013; España et al., 2013; Mayes et al., 2011; Shuptrine et al., 2012; Stathis and Ghielmini, 2012).Com o intuito de minimizar os efeitos adversos dos anticorpos anti-rituximabe e aumentar a atividade efetora da terapia a busca por anticorpos molecularmente engenheirados é feita por vários grupos de pesquisa.(Alduaij and Illidge, 2011; de Lorenzo-Pinto et al., 2013; Fernández et al., 2015; Holliger and Hudson, 2005; Maloney, 2012; Pateinakis and Pyrpasopoulou, 2014; van Oers and Kersten, 2011).

Atualmente existem três gerações de anticorpos anti-CD20, alguns em fases de teste e outros aprovados para uso clínico (Tabela 2). Os anti-CD20 de primeira geração são os anticorpos murinos ou quiméricos, como o rituximabe, os de segunda geração são aqueles modificados para redução da imunogenecidade (humanizados e humanos) e os de terceira geração, além de serem humanizados ou humanos possuem modificações na porção efetora Fc para aumentar a afinidade pelos seus receptores (FcR) e consequentemente aumentar sua atividade efetora (Fernández et al., 2015; Oflazoglu and Audoly, 2014).

Tabela 2 Anticorpos anti-CD20 aprovados ou em fases de teste clínico. Adaptada do site da Food Drug Administration

\begin{tabular}{|c|c|c|c|c|c|}
\hline Anticorpo & Forma & Tipo & Indicação & Empresa & $\begin{array}{c}\text { Ano de } \\
\text { aprovação ou } \\
\text { Fase de teste }\end{array}$ \\
\hline Rituximabe & Quimérico & I & NHL, RA & Genentech & 1997 \\
\hline Ibritumomabe & Murino & I & NHL & Biogen IDEC & 2002 \\
\hline
\end{tabular}




\begin{tabular}{|c|c|c|c|c|c|}
\hline Anticorpo & Forma & Tipo & Indicação & Empresa & $\begin{array}{c}\text { Ano de } \\
\text { aprovação ou } \\
\text { Fase de teste }\end{array}$ \\
\hline Zevalin & & & & & \\
\hline $\begin{array}{l}\text { Tositumomabe } \\
\text { Bexxar }\end{array}$ & Murino & II & NHL & GlaxoSmithKline & 2003 \\
\hline $\begin{array}{c}\text { Ofatumumabe } \\
\text { Arzerra }\end{array}$ & Humano & I & $\begin{array}{l}\text { NHL, RA, } \\
\text { CLL }\end{array}$ & $\begin{array}{c}\text { Genmab, } \\
\text { GlaxoSmithKline }\end{array}$ & 2009 \\
\hline Ocrelizumabe & Humanizado & I & NHL, RA & $\begin{array}{c}\text { Genentech, } \\
\text { Roche, Biogen }\end{array}$ & Fase 3 \\
\hline Veltuzumabe & Humanizado & I & NHL, ITP & Immunomedics & Fase 2 \\
\hline Obinutuzumabe & Humanizado & II & $\begin{array}{l}\text { NHL, } \\
\text { CLL }\end{array}$ & Roche & Fase 2 \\
\hline AME-133v & Humanizado & I & NHL & $\begin{array}{l}\text { Applied } \\
\text { Molecular } \\
\text { Evolution }\end{array}$ & Fase 2 \\
\hline TRU-015 & $\mathrm{FvFc}$ & II & RA & Trubion Pharma & Fase 2 \\
\hline PRO131931 & Humanizado & I & $\begin{array}{l}\text { NHL, } \\
\text { CLL }\end{array}$ & Genentech & Fase $1 / 2$ \\
\hline GA-101 & Humanizado & II & $\begin{array}{l}\text { CLL, } \\
\text { NHL }\end{array}$ & Glycart / Roche & Fase $1 / 2$ \\
\hline
\end{tabular}

Tabela 2. Anticorpos anti-CD20 aprovados ou em fases de teste clínico até 2012. NHL = Linfoma nonHodgkin. CLL = Leucemia linfocítica crônica. RA = Artrite reumatoide. ITP = Púrpura trombocitopenia idiopática autoimune. Adaptada do site da Food Drug Administration Disponível em: http://www.antibodysociety.org/news/approved_mabs.php). 
Os anticorpos anti-CD20 podem ser divididos também em dois tipos de acordo com a sua principal forma de depleção das células B alvo. Os do tipo I atuam principalmente pela formação de balsas lipídicas na membrana dessas células levando a um agrupamento dos anticorpos e aumento da atividade efetora via complemento, como é o caso do rituximabe e do ofatumumabe. Já os do tipo II atuam principalmente por indução de morte celular disparada por adesão homotípica e pela via lisossomal, como é o caso do tositumomabe e obinutuzumabe (Beers et al., 2010; Herter et al., 2013).Curiosamente ambos os tipos se ligam ao CD20 por meio dos mesmos resíduos presentes no motivo ANP (170-172), mas aparentemente os do tipo I se ligam a uma porção N-terminal do motivo, enquanto os do tipo II se ligam ao mesmo epítopo, mas pelo seu lado carboxi-terminal (Herter et al., 2013).Essa diferença sutil induz alterações de conformações diferentes desse domínio extracelular, possibilitando o reconhecimento de diferentes subpopulações/orientações das moléculas de CD20 na superfície da célula (Figura 7)Regimes terapêuticos empregando os dois tipos de Ac têm sido testados, mostrando sucesso quando utilizados de maneira alternada ou em combinação.(Seiter and Mamorska-Dyga, 2015) 


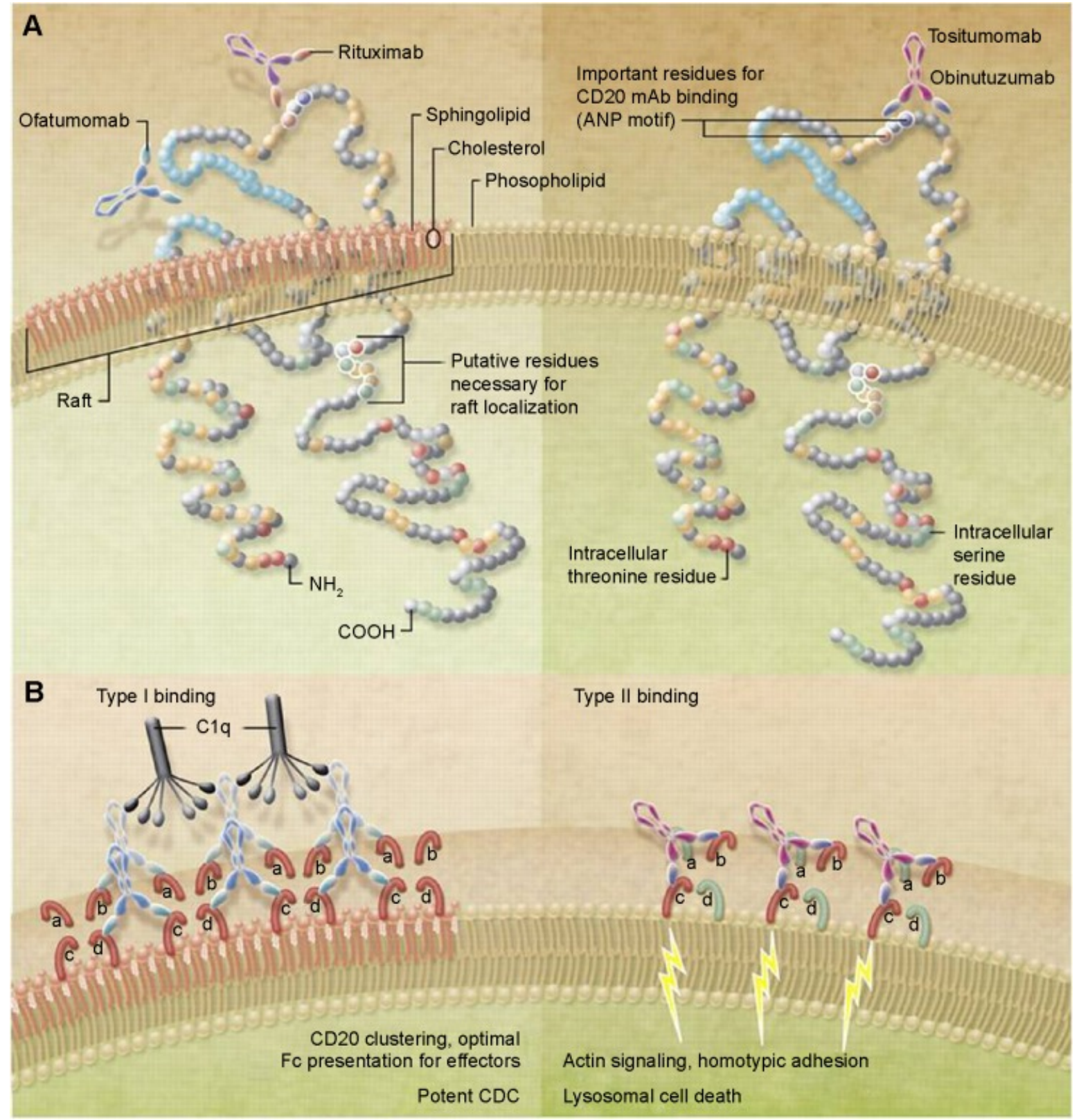

Figura 7. Representação esquemática da forma de atuação dos anticorpos anti-CD20 de tipo I e II.Anticorpos do tipo I, como o rituximabe e ofatumumabe atuam principalmente pela formação de balsas lipídicas levando a um agrupamento dos anticorpos e aumento da atividade efetora via complemento. Já os do tipo II atuam principalmente por indução de apoptose celular e ADCC, como é o caso do tositumomabe e obinutuzumabe (adaptada de (CRAGG, 2011; Seiter and Mamorska-Dyga, 2015).

Alguns anti-CD20 diferentes do rituximabe já estão em fases de teste e até mesmo aprovados para uso em alguns países para determinadas patologias, dentre eles estão outros anticorpos murinos como o Tositumomabe, humanizados como o Ocrelizumabe, humanos como o Ofatumumabe e com a porção Fc modificada, como o GA-101 (Beers et al., 2010; Bologna et al., 2013; da Silva et al., 2008; de Lorenzo-Pinto et al., 2013; Du et al., 2007; 
Herter et al., 2013; Johnson et al., 2009; Kim et al., 2005; Klein et al., 2012; Maloney, 2012; Mayes et al., 2011; Montraveta et al., 2014; Seiter and Mamorska-Dyga, 2015; Wang et al., 2014; Weiner et al., 2010).

\subsection{Rituximabe}

É um anticorpo monoclonal específico para antígeno CD20, o qual é uma fosfoproteína de membrana que regula a condutância de cálcio, sendo expresso nos linfócitos B normais, nos linfoma não-Hodgkin derivados de células B e em 93\% e nas células da leucemia linfócítica crônica até em 99\% (Alduaij and Illidge, 2011; Binder et al., 2006; Fernández et al., 2015; Herter et al., 2013; Pateinakis and Pyrpasopoulou, 2014). Este mAb é gerado pela técnica do hibridoma, que produz citotoxicidade das células alvo, por meio do complemento ou da citotoxicidade celular dependente de anticorpos (CDC). Devido a ligação da proteína $\mathrm{C} 1 \mathrm{q}$ do complemento e das regiões $\mathrm{Fc}$ do anticorpo quimérico as quais ficam expostas (Binder et al., 2006; Du et al., 2007; Eisenberg and Looney, 2005; Herter et al., 2013; Pateinakis and Pyrpasopoulou, 2014) (Figura 8). 


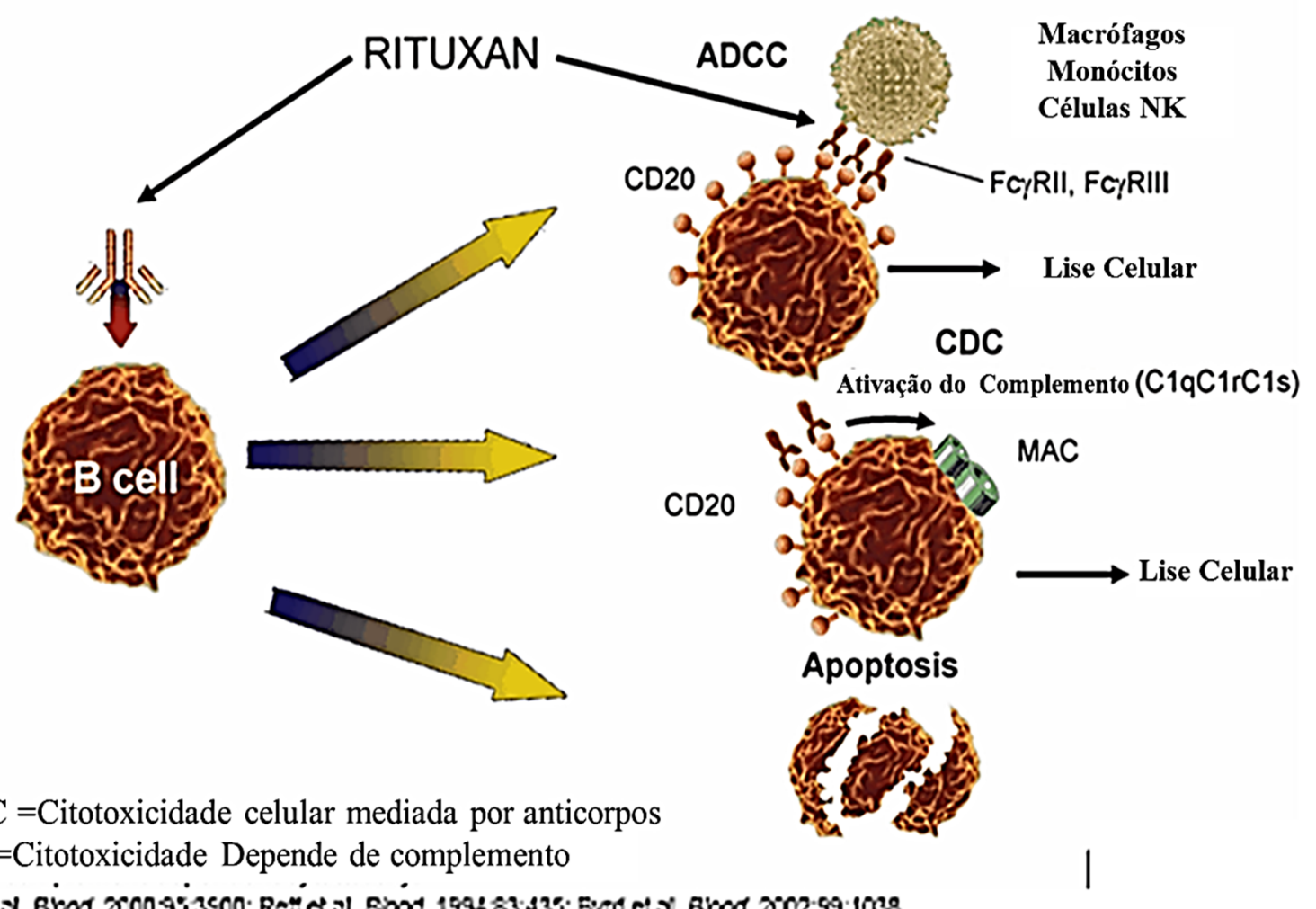

ADCC $=$ Citotoxicidade celular mediada por anticorpos $\mathrm{CDC}=$ Citotoxicidade Depende de complemento

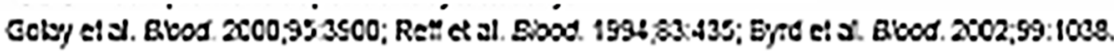

Figura 8: Recrutamento dos mecanismos efetores imunes por meio do domínio Fc humano na ação do rituximabe. $\mathrm{O}$ rituximabe demonstra induzir apoptose in vitro em células B de linfoma (Du et al., 2007; Fernández et al., 2015).

O CD20 não é expresso em células progenitoras da medula óssea, pelo qual se considera que o tratamento a este nível eliminará clones que expressam o antígeno mencionado, mas não afetarão as células pluripotenciais (stem cell) que posteriormente podem repovoar a medula óssea com linfócitos normais. Muito menos se expressa nas células plasmáticas e em seus derivados oncogênicos ou em componentes de linfócitos T (Binder et al., 2006; Fernández et al., 2015; Pateinakis and Pyrpasopoulou, 2014). Uma das vantagens do alvo antigênico é não ser interno para conectar-se ao anticorpo monoclonal e por sua expressão ser estável. Esta característica, entre outras, faz do rituximabe uma terapia poderosa em linfomas nãoHodgkin e outras neoplasias que sobreexpresan CD-20.

\subsection{Expressão Em Células De Mamífero}

A tecnologia de expressão de moléculas recombinantes em células de mamíferos é o principal meio de produção proteínas recombinantes. Na atualidade muitas destas proteínas são expressas em Ovário de Hamster Chinês (CHO), mas outras linhas celulares, tais como 
os de mieloma derivado de camundongo (NS0), células de rim de hamster (BHK), células de rim de embrião humano (HEK-293) e células da retina humanas (PERC6), são sistemas otimizados para a produção de biofarmacos.

As células CHO são o sistema de expressão predominantemente para transfecção estável empregado para a produção de biofármacos pelo amplo conhecimento físiológico e de cultivo que se tem dessas células, bem como pela segurança que oferece em relação à suscetibilidade a patógenos humanos. Essas células possuem a capacidade de realizar modificações pós-traducionais, tais como, a $N$-glicosilação, acetilação, metilação, fosforilação, glicosilação, prenilação, sulfonação, de forma bastante similar às endonuclease de linhagem celulares humanas, modificações pós-traducionais que ocorrem no retículo endoplasmático e no complexo de Golgi. Os resíduos de glicanos são ligados covalentemente na cadeia polipeptídica, normalmente via ligações $\mathrm{N}$ ou $\mathrm{O}$. $\mathrm{N}$-glicosilações consistem de uma cadeia de açúcar covalentemente ligada a um resíduo de asparagina (Asn), comumente envolvendo um resíduo de $N$-acetilglicosamina (GlcNAc) e a sequência peptídica consenso Asn-X-Ser/Thr. Nglicanos compartilham um núcleo de pentassacarídeo e podem ser divididos em três classes: tipo oligomanose (ou alta manose), tipo complexo e tipo híbrido. Por outro lado, $O$-glicosilações geralmente envolvem a ligação de um resíduo de $N$ acetilgalactosamina (GalNac) a um grupo hidroxil de um resíduo de serina (Ser) ou treonina (Thr) e apresentam uma grande variedade de núcleos (Varki et al.). Essas estruturas de glicanos chegam a formar complexas redes ramificadas que garantem o correto enovelamento proteico, o tempo de vida e, muitas vezes, a atividade biológica das proteínas às quais são ligadas. Além disso está linhagem celular vem sendo usada extensivamente e com sucesso, com um excelente prognóstico em segurança viral. Viroses humanas patogênicas como Pólio, Rubéola, Herpes, Hepatite B, HIV, Sarampo, Influenza e Adenoviroses, não se replicam em células CHO. Assim, o risco de contaminação involuntária e transmissão de um agente viral adventício são extremamente reduzidos, é uma linhagem de fácil manipulação e controle de cultivo. Por isso, é empregada na produção de diversos produtos recombinantes (Wurm, 2004) (Jayapal et al., 2007; Kim et al., 2012).

Alternativamente, existe um número grande de tipos celulares disponíveis para a produção de proteínas glicosiladas que tenham modificações pós-traducionais com 
compatibilidade imunológica para uso em seres humanos. Uma de elas e a linhagem celular HEK293 Por serem de origem humana, de rim embrionário (Human Embryonic Kidney), também possuem um sistema de modificação pós-traducional que garante a segurança de proteínas terapêuticas superexpressas, somado ao fato de possuírem uma robusta maquinaria de síntese proteica e alta taxas de replicação (Thomas and Smart, 2005) A célula HEK também é uma escolha popular por sua alta eficiência de transfecção e produção de proteína; tradução fiel e processamento de proteínas. (Varki et al 2009)

A transfecção pode ser alcançada com maior sucesso usando vetores de expressão otimizados para isso, esses vetores terão gene recombinante e o gene de seleção, os quais serão expressos a partir de um RNAm policistrónico, para aumentar a oportunidade de obtenção de alto número linhas celulares produtoras, o marca seletiva pode ser conduzido a partir de um promotor débil. Embora este método geralmente reduza a eficiência de transfecção estável, as células que sobrevivem à seleção produzem mais proteína recombinante. Quando estas características estão presentes no mesmo vetor, podem ser expressos de forma policistrónica o que confere e permite a expressão de locais de entrada do ribossoma internos (IRES, Inglês, entrada site ribossoma). Ao ser adicionado entre o gene de interesse e uma marca seletiva, o IRES permite a tradução dos dois genes, devido à origem de um sítio interno para entrada de ribossomos sem a necessidade de todo o aparato de iniciação da tradução presente em eucariotos (Gutiérrez-Escolano, 2006) (Figura 9).

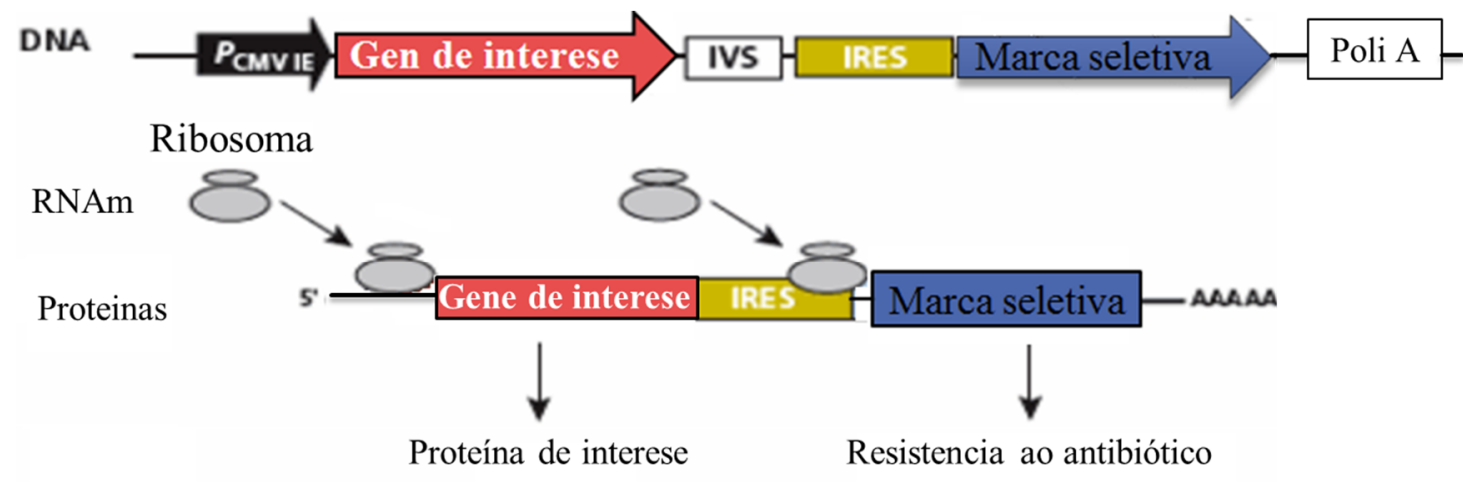

Figura 9: Mecanismo de ação do sítio de entrada ribossomal interno. IRES, do inglês, Interna Ribosome Entry Site, promotor CMV, gene de interesse, marca seletiva. IVS: íntron sintético. Poli A: sinal de poliadenilação (Clontech). 
Após à transfecção, o transgene é transportado para o núcleo e incorporado no genoma por recombinação não homóloga. O sítio de ligação do transgene tem um papel importante na transcrição do gene recombinante. A Integração em regiões de Heterocromatina ocasiona uma baixa expressão ou o bloqueio do processo, embora a integração de regiões de eucromatina pode ser insuficiente para permitir uma expressão a longo prazo. Em geral, a expressão do transgene é silenciada rapidamente, provávelmente pela influência das regiões de cromatina condensada perto do local de integração ou devido a efeitos epigenéticos tais como a metilação e a acetilação de histonas e a metilação do DNA (Kim et al., 2012; Kito et al., 2002).

O soro fetal bovino adicionado ao meio de cultura em concentrações de 1 a $20 \%$, é essencial para a propagação das células de mamíferos(Wurm, 2004). O soro bovino é uma fonte abundante de hormônios, fatores de crescimento e elementos que promovem o rápido crescimento celular. Além disso, a presença de grande quantidade de albumina garante proteção às células contra condições adversas como variações do pH e pressão osmótica. Contudo, a composição do soro é variável e indefinida, o que possibilita um crescimento e Produção inconsistente. $\mathrm{O}$ custo da adição de grandes quantidades de soro torna o processo excessivamente oneroso. E, por último, a presença de uma vasta quantidade de proteínas no soro fetal bovino prejudica o processo de purificação da proteína recombinante. Esse fator é especialmente impactante sobre a produção de mAbs recombinantes, uma vez que o soro possui grandes quantidades de anticorpos bovinos, moléculas muito similares aos anticorpos produzidos, dificultando a purificação e encarecendo ainda mais o processo de produção.

Atualmente, os processos de produção de anticorpos em larga escala são executados em meios de cultivo sem soro fetal bovino. A composição dos meios de cultura modernos suporta um excelente desempenho da cultura de células na falta de peptídeos fornecidos pelo soro, fatores de crescimento e uma indefinida coleção de proteínas, lipídeos, carboidratos e pequenas moléculas (Wurm, 2004).

A forma de cultivo possui papel chave na taxa de expressão de proteínas recombinantes. Dois formatos principais vêm sendo empregados em culturas de células de mamíferos: a cultura de células aderidas e as culturas em suspensão, sendo o cultivo em 
células aderidas a mais comum. A cultura de células aderentes é uma técnica mais simples perto dos complexos processos de produção em suspensão existentes(Jayapal et al., 2007).

Com intuito de produzir glicoproteínas estáveis, têm-se utilizado células de mamíferos como sistema de expressão heteróloga, pois estas possuem uma maquinaria póstraducional necessária para estabilizar biomoléculas complexas. Para este objetivo foram construídos vetores otimizados para a produção dessas proteínas recombinantes em células de mamíferos um exemplo é o vetor pCOMIRES $\Delta 600$ (Quilici et al., 2013) (Figura 10)

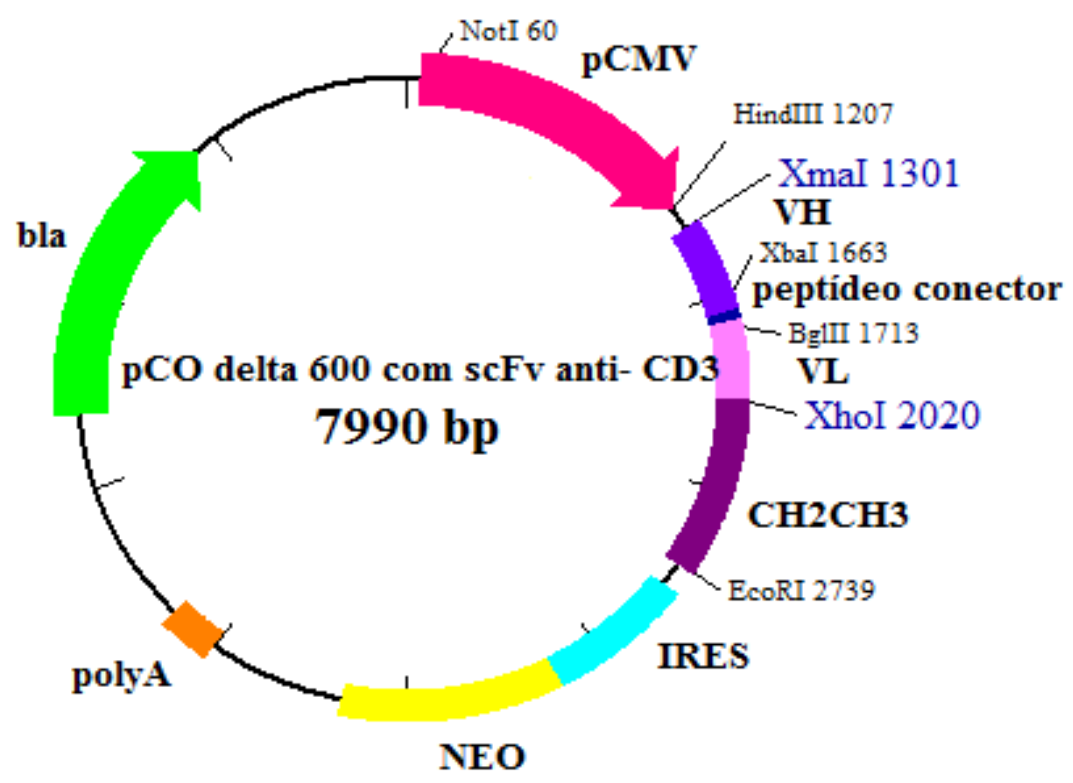

Figura 10: Representação gráfica do mapa físico do vetor pCOmires $\mathbf{\Delta 6 0 0}$ antiCD3 humanizado (Quilici et al., 2013)

$\mathrm{O}$ vetor pCOMIRES $\triangle 600$ possui os genes relacionados com as cadeias $\mathrm{CH} 2$ e $\mathrm{CH} 3$ do Fc de imunoglobulina humana IgG, que estão presentes entre o sítio da enzima Xho I e da enzima $E c o R$ I, de forma que a proteína liberada pela célula de mamífero corresponda ao fragmento $\mathrm{FvFc}$ do anticorpo (Quilici, 2012). O vetor pCOMIRES $\Delta 600$, também possui: gene para resistência á ampicilina (bla), que facilita a manipulação em bactéria e o gene de resistência a geneticina $\left(\mathrm{NEO}^{\mathrm{R}}\right)$, para a seleção de transfectomas estáveis (Sousa, 2013).

Os genes que codificam o fragmento $\mathrm{FvFc}$ estão em fase com a sequência líder, codificadora do peptídeo sinal de imunoglobulina, dirigindo assim os produtos recombinantes para o aparato secretório da célula (Sousa, 2013). A expressão do gene é dirigida pelo promotor CMV (Citomegalovírus). Este promotor tem como principal 
característica promover altos níveis de transcrição do gene da proteína recombinante (Mariati et.al., 2010). Para tanto ele possui o íntron A com uma deleção de 600 pares de base (Quilici et al., 2013). O íntron A é responsável para que a performance do processo de splicing ocorra de forma a permitir maior fidelidade de transcrição do FvFc, que encontra-se clonado como cDNA (Le Hir et al., 2003). O vetor também possui o sinal de poliadenilação eficiente do vírus 40 de macaco SV40 (Smian Vírus 40) que codifica a "cauda polyA” do RNA (Le et.al., 2003).

Outra característica importante é que o gene de resistência a geneticina $\left(\mathrm{NEO}^{\mathrm{R}}\right)$ está clonado a montante a um elemento IRES (do inglês Internal Ribossome Entry Site). O IRES consiste em sequências localizadas na região 5 UTR (do inglês Untranslated Region) de alguns vírus de RNA e sua presença em um vetor de expressão é considerada extremamente importante para possibilitar a expressão policistrônica por permitir uma expressão duradoura e estável de proteínas recombinantes, como imunoglogulinas (Gutiérrez-Escolano, 2006)

Essa característica faz com que tanto o mRNA gerado a partir do cassete de expressão contenha a sequência codificadora da proteína recombinante, o IRES e a sequência que codifica a marca seletiva Neo. Esse mRNA serve de molde para a tradução simultânea de ambos os cistrons, de forma que ao se selecionar a célula pela sua resistência a geneticina, seleciona-se aquele com capacidade de produzir proteína recombinante (Houbebine et.al., 1999). (Gutiérrez-Escolano, 2006)

Assim com estas ferramentas moleculares o grupo de Imunologia Molecular da Universidade de Brasília trabalha na produção de proteínas heterólogas em células de mamífero desde 2001, sendo anticorpos recombinantes e humanizados já produzidos de interesse clínico visando a sua aplicação terapêutica comercial como o anti-CD18 (Caldas et al., 2000), e anti-CD3(Silva et al., 2009a) e deste modo, foi proposta a humanização e produção de anticorpos anti-CD20 totalmente humanos em células de mamíferos que foram gerados pela tecnologia de $\mathbf{V}$ domain shuffling e selecionados por phage display pela aluna de doutorado Barbara Maciel Sidou Pimentel (dados não publicados). 


\section{OBJETIVOS}

\subsection{Objetivo geral}

Este projeto tem como objetivo a produção de novos anticorpos monoclonais humanos anti-CD20 na forma de FvFc em células de mamíferos.

\subsection{Objetivos específicos}

1- Síntese dos genes codificadores dos scFvs ligantes.

2- Clonagem dos genes em vetores de expressão de $\mathrm{FvFc}$ em células de mamíferos.

3- Obtenção de transfectomas de células $\mathrm{CHO}$ produtoras de $\mathrm{FvFc}$ anti- $\mathrm{CD} 20$

4- Purificação das proteínas recombinantes no sobrenadante de cultura de populações mistas transfectadas. 


\section{MATERIAIS E MÉTODOS}

\subsection{Materiais}

\subsubsection{Células}

\section{- Linhagens de Escherichia coli}

XL1-Blue (Stratagene®) - recAl endA1 gyrA96 thi-1 hsdR17 supE44 relAl lac[F' proABlacIqZ M15Tn10 (TetR)] (Sambrook e Russel, 2001).

\section{- Linhagens de células de mamífero}

CHO-K1 (ATCC: CCL-61): Linhagem celular derivada da subclonagem de uma célula epitelial de ovário de hamster Chinês (CHO) parental, iniciada pela biópsia de um ovário da fêmea adulta do hamster Chinês Cricetulusgriseus. São células epiteliais que crescem aderidas a superfície e necessitam de suplementação de soro fetal bovino e prolina ao meio de cultura. As células foram cultivadas em meio HAM-F12 (Hyclone) contendo soro fetal bovino (SFB) a uma concentração de $10 \%$ (v/v)

HEK 293 (ATCC CRL1573): E uma linha celular derivada a partir de células de rim embrionário humano crescidas em cultura de tecidos que contêm o genoma do adenovírus tipo 5, é amplamente utilizada como uma ferramenta para a expressão de proteínas recombinantes, Mesmo que sejam de origem epitelial, a sua maquinaria bioquímica é capaz de executar a maior parte da dobragem subsequente e de tradução necessárias para gerar a proteína madura funcional a partir de um largo espectro de ambos os mamíferos de processamento de ácido nucleico e não mamíferos. Embora populares como um sistema de expressão transiente, as células também tem visto ampla utilização nas formas estavelmente 
transfectadas. As células foram cultivadas em meio DMEM (GIBCO) contendo SFB a uma concentração de $10 \%$ (v/v).

\subsubsection{Plasmídeos}

A continuação se indica os vetores de expressão usado neste estudo para a clonagem, e os plasmídeos para transfretarem células de mamífero.

pCO 4600 antiCD3 humanizado. Vetor de 7990 bp foi utilizado nesse trabalho para alcançar o objetivo da Clonagem do fragmento de anticorpo Hibrido-Rituximabe na forma scFv e como controle negativo nos experimentos de transfecção contém; promotor de cytomegalovirus com deleção de 600 pb. Lp: peptídio sinal. Fv: fragmento variável cadeia simples de aCD3. aCD3Fc: fragmento cristalizável. IRES: sítio de entrada ribossomal interno. Neo: gene de resistência ao antibiótico G418, poli A: sinal de poliadenilação. Bla: gene de resistência a ampicilina para clonagem bacteriana

pBSK-scFV Hibrido-Ritux -VLHumana: Vetor de 3629pb que contem (f1ori) fragmento de restrição que contêm o origem de replicação de DNA do bacteriófago f1, usado para transfectar em E. coli, gene lacZ que codifica o fragmento amino-terminal da enzima $\beta$ galactosidase, gene que codifica o fragmento scFV Hibrido-Ritux -VLHumana, e gene de resistência a ampicilina.

pCOMIRES 6600 com a versão humanizada scFv A : Vetor de 7990 bp versão scFv humanizada. Construído por (Zaparolli 2015). Foi utilizado para a produção.

pCOMIRES 6600 com a versão humanizada scFv L : Vetor de 7999bp versão scFv humanizada construído por Zaparolli (2015). Foi utilizado para a produção.

pCOMIRES $\triangle 600$ com a versão murina scFv O : Vetor 7999 bp versão scFv murina similar à do Rituximabe original construído por (Zaparolli 2015). Foi utilizado para a produção.

pGFP/NEO: $11,2 \mathrm{~kb}$, Possui promotor de timidina quinase (pTK), $\mathrm{NEO}^{\mathrm{R}}$ sítio múltiplo de clonagem, sinal de poliadenilação TkpA, promotor pRSV-LTR, sinal de poliadenilação 
SV40polyA, origem de replicação ORI e gene da $\beta$-lactamase (bla). Utilizado para visualização da eficiência das transfecções por possuir o gene repórter que codifica a proteína fluorescente verde (GFP, do inglês, Green Fluorescent Protein).

\subsubsection{Soluções estoques de inibidores de proteases}

\section{PMSF (PhenilmethylsulfonylFluoride) 0,1 M}

Solubilizado em isopropanol e estocado a temperatura ambiente por até 1 ano. É um inibidor de serino e tiol proteases como, por exemplo, tripsina, quimiotripsina, trombina, papaína etc. Adicionar a uma concentração final de $1 \mathrm{mM}$.

\section{EDTA (Ácido TetracéticoEtilenodiamina) 0,5M}

Solubilizado em água, pH 8-9, estocado a $4{ }^{\circ} \mathrm{C}$ por até 6 meses. É um inibidor de metaloproteases. Adicionar a uma concentração final de $5 \mathrm{mM}$.

\section{Azida Sódica - Solução estoque 100X}

Azida sódica 5\% (p/v)

Esta solução era utilizada para a conservação dos tampões PBS e PBS-T e nas soluções estoque dos anticorpos em concentração final de $0,05 \%(\mathrm{p} / \mathrm{v})$.

\subsubsection{Meios De Cultura Para Bactérias}

\section{Meio LB (Luria-Bertani)}

Peptona de caseína $1,000 \%(\mathrm{p} / \mathrm{v})$

Extrato de levedura $0,500 \%(\mathrm{p} / \mathrm{v})$

$\mathrm{NaCl} 1,000 \%(\mathrm{p} / \mathrm{v})$

$\mathrm{pH} 7,0$.

\section{Meio LB ágar}

Meio LB adicionado de ágar bacteriológico a 1,400\% (p/v). 


\section{Meio SB (Super- Broth)}

Peptona de Caseína 3,000\% (p/v)

Extrato de Levedura 2,000\% (p/v)

MOPS $1,000 \%(\mathrm{p} / \mathrm{v})$

$\mathrm{pH} 7,0$

\section{Meio SOB}

Bacto-triptona 2,000\% (p/v)

Extrato de levedura $0,500 \%(\mathrm{p} / \mathrm{v})$

$\mathrm{NaCl} 0,060 \%(\mathrm{p} / \mathrm{v})$

$\mathrm{KCl} 0,002 \%(\mathrm{p} / \mathrm{v})$

$\mathrm{pH} 7,0$.

\section{Meio SOC}

Meio SOB $98 \mathrm{~mL}$

Solução estoque de $\mathrm{Mg}_{2}+2 \mathrm{M} 1 \mathrm{~mL}$

Solução estoque de glicose $2 \mathrm{M} 1 \mathrm{~mL}$

Após dissolver os reagentes em água destilada, todos os meios de cultura foram autoclavados

a $120^{\circ} \mathrm{C}$ por 15 minutos.

\subsubsection{Meios de cultura e soluções para cultura de células de mamíferos}

Meio Ham-F12 com L-glutamina a 2 mM(Gibco®, no catálogo: 21700-026)

Meio Base 1 pacote

$\mathrm{NaHCO}_{3} 1,176 \mathrm{~g}$

$\mathrm{dH}_{2} \mathrm{O}$ q.s.p $1,000 \mathrm{~L}$

$\mathrm{pH} 7,2$

\section{Meio de Congelamento de Células}

Meio Ham-F12 com L-glutamina

Soro Fetal Bovino $20 \%$ (v/v) 
DMSO 5\% (v/v)

Solução salina balanceada (HBSS - Hank'sBalanced Salt Mixture)

(HyClone®, no catálogo: SH30015.01)

Mistura base 1 pacote

$\mathrm{NaHCO}_{3} 0,350 \mathrm{~g}$

$\mathrm{dH}_{2} \mathrm{O}$ q.s.p $1,000 \mathrm{~L}$

$\mathrm{pH} \mathrm{7,4}$

Tripsina-EDTA (Invitrogen®, no catálogo: 27250-018)

Tripsina $2,500 \mathrm{~g}$

EDTA $0,380 \mathrm{~g}$

HBSS qsp 1,000 L

$\mathrm{pH} 8,0$

Soro Fetal Bovino (LGC Biotecnologia®, no catálogo: 10-bio500)

Estocar de -5 a -20 oC.

Adicionado ao meio de cultura Ham-F12 com L-glutamina à concentração de $10 \%$ ou $20 \%$ $(\mathrm{v} / \mathrm{v})$.

\section{Azul de Tripan}

Corante Azul de Tripan 400 mg

PBS pH 7,2 q.s.p. $100 \mathrm{~mL}$

Reagente de transfecção JetPEI ${ }^{\mathrm{TM}}$ (PolyplusTransfection, $\mathrm{n}^{\circ}$ de catálogo 101-01N).

É um lipídeo catiônico cuja formulação específica permite a transfecção de diversas linhagens de células de mamífero.

\subsubsection{Soluções e tampões de uso geral}

\section{Tampão TE}


Tris- $\mathrm{HCl} \mathrm{pH} 8,010 \mathrm{mM}$

EDTA pH 8,0 $1 \mathrm{mM}$

Tampão Tris

Tris-HCl pH 8,0 10 mM

\section{Glicogênio}

Glicogênio $20 \mathrm{mg} / \mathrm{mL}$

\section{Glicerol - Solução estoque}

Glicerol 50\% (v/v)

Tampão PBS (Phosphate-Buffered Saline) 10X, pH 7,4

$\mathrm{NaCl} 1,50 \mathrm{M}$

$\mathrm{Na}_{2} \mathrm{HPO}_{4}$ 0,10 M

$\mathrm{NaN}_{3} 0,02 \%(\mathrm{p} / \mathrm{v})$

\section{Tampão PBS-T 1X, pH 7,4}

PBS 1X acrescido de Tween 20 na concentração final de 0,10\% (v/v)

3.1.7. Soluções e material para preparo de células competentes e transformação bacteriana por eletroporação

Solução estoque de glicose $2 \mathrm{M}$

Esterilizada por filtração e estocada a $4^{\circ} \mathrm{C}$.

Solução estoque de Mg 2 M

$\mathrm{MgCl}_{2} 1 \mathrm{M}$

$\mathrm{MgSO}_{4} 1 \mathrm{M}$

Esterilizada por filtração e estocada a $4^{\circ} \mathrm{C}$. 


\section{Glicerol $10 \%(\mathrm{v} / \mathrm{v})$}

Esterilizado por filtração e estocada a $4^{\circ} \mathrm{C}$

\section{Solução de X-Gal}

Solução de 5-bromo-4-cloro-3-indolil- $\beta$-D-galactosídeo (X-Gal) dissolvido em N,Ndimetilformamida em solução estoque de $2,5 \%$. Solução armazenada a $-20^{\circ} \mathrm{C}$ e protegida da luz. Usada no meio de cultura na proporção de 1:100.

\section{Solução de IPTG}

Solução de isopropil-tio- $\beta$-D-galactosídeo (IPTG) dissolvido em água em solução estoque de $100 \mathrm{mM}$ e esterilizado por filtração em membrana Millipore de $0,22 \mu \mathrm{m}$. Usada no meio de cultura na proporção de 1:1000

\section{Ampicilina}

A ampicilina liofilizada foi ressuspendida em água destilada na concentração de 20 a 50 $\mathrm{mg} / \mathrm{mL}$. Após a ressuspensão, ela foi esterilizada por filtração em membrana Millipore de $0,22 \mu \mathrm{m}$. Após a filtração, foi estocada a $-20^{\circ} \mathrm{C}$ e protegida da luz. Antibiótico utilizado como marca de seleção para plasmídios transformados em células de $E$. coli

Cubetas de eletroporação (Gene Pulser/MicroPulserCuvettes, Biorad®, no catálogo: 165-2086)

\subsubsection{Soluções e material para preparo de células competentes e transformação bacteriana por $\mathrm{CaCl} 2$}

\section{Solução de CaCl2}

$\mathrm{CaCl}_{2} 50 \mathrm{mM}$

Esterilizada por filtração e estocada a $4^{\circ} \mathrm{C}$ 
Solução de CaCl2 + 15\% de Glicerol (v/v)

$\mathrm{CaCl} 250 \mathrm{mM}$

Glicerol 15\%

Esterilizada por filtração e estocada a $4^{\circ} \mathrm{C}$

\subsubsection{Soluções Para Extração De DNA Plasmideal}

\section{Solução I}

Tris-HCl pH 8,0 25 mM

EDTA pH 8,0 $10 \mathrm{mM}$

Glicose $50 \mathrm{mM}$

Solução II

$\mathrm{NaOH} 0,2 \mathrm{M}$

SDS $1,0 \%(\mathrm{p} / \mathrm{v})$

\section{Solução III}

Acetato de potássio $3 \mathrm{M}$

Ácido Acético $2 \mathrm{M}$

pH ajustado para 4,8 - 5,0

RNAse A

RNAse A (Invitrogen®, no de catálogo 12091-021).

\section{Clorofane}

Fenol equilibrado em pH 7,6 1 v

Clorofórmio $1 \mathrm{v}$

B-hidroxiquinilona $0,05 \%(\mathrm{p} / \mathrm{v})$

Equilibrado com 0,1 v de Tris-HCl $100 \mathrm{mM} \mathrm{pH} \mathrm{7,6}$

\section{Clorofil}

Clorofórmio $24 \mathrm{v}$ 
Álcool isoamílico $1 \mathrm{v}$

Equilibrado com $0,25 \mathrm{v}$ de tampão TE

Etanol 100\%

Etanol 100\% (v/v)

Etanol 70\%

Etanol 70\% (v/v)

Isopropanol $100 \%$

Isopropanol 100\% (v/v)

Acetato de sódio $3 \mathrm{M}, \mathrm{pH}$ 4,8

Utilizada para precipitação de DNA em preparação de pequena escala.

Acetato de amônio 7,5 M

Utilizada para precipitação de DNA em preparação de larga escala.

\subsubsection{Tampões de Endonucleases de Restrição}

Fermentas®:

Tango TM (10X)

Tris-Acetato pH 7,9 $33 \mathrm{mM}$

Acetato de Magnésio $10 \mathrm{mM}$

Acetato de Potássio $66 \mathrm{mM}$

BSA $0,1 \mathrm{mg} / \mathrm{mL}$

Fast Digest Buffer TM (10X)

New England Biolabs®:

NEBuffer 1 (1X)

Bis-Tris-propano- $\mathrm{HCl} \mathrm{pH} \mathrm{7,0} 10$ mM 
$\mathrm{MgCl}_{2} 10 \mathrm{mM} 33$

DTT $1 \mathrm{mM}$

NEBuffer 2 (1X)

Tris-HCl pH 7,9 10 mM

$\mathrm{MgCl}_{2} 10 \mathrm{mM}$

DTT $1 \mathrm{mM}$

NEBuffer 3 (1X)

Tris- $\mathrm{HCl} \mathrm{pH}$ 7,9 $150 \mathrm{mM}$

$\mathrm{MgCl}_{2} 10 \mathrm{mM}$

$\mathrm{NaCl} 100 \mathrm{mM}$

DTT $1 \mathrm{mM}$

NEBuffer 4 (1X)

Tris-Acetato $\mathrm{pH}$ 7,9 $20 \mathrm{mM}$

Acetato de Magnésio $10 \mathrm{mM}$

Acetato de Potássio $50 \mathrm{mM}$

DTT $1 \mathrm{mM}$

\subsubsection{Tampões de outras reações}

Tampão de Reação 5X da T4 DNA ligase(Invitrogen®)

Tris-HCl $250 \mathrm{mM}$

$\mathrm{MgCl}_{2} 50 \mathrm{mM}$

ATP $5 \mathrm{mM}$

DTT $5 \mathrm{mM}$

PEG-8000 25\% (p/v)

$\mathrm{pH} \mathrm{7,6}$

Tampão de Reação 10X da T4 DNA ligase(Biolabs®)

Tris- $\mathrm{HCl} \mathrm{pH}$ 7,5 500 mM 
$\mathrm{MgCl}_{2} 100 \mathrm{mM}$

DTT $100 \mathrm{mM}$

ATP $10 \mathrm{mM} 34$

Tampão de Reação 10X da T4 DNA ligase(Promega $\left.{ }^{\circledR}\right)$

Tris-HCl pH 7,6 300 mM

$\mathrm{MgCl}_{2} 100 \mathrm{mM}$

DTT $100 \mathrm{mM}$

ATP $10 \mathrm{mM}$

\subsubsection{Endonucleases de restrição.}

Fermentas@:

$C f r 9 \mathrm{I}(1,5 \mathrm{U} / \mu \mathrm{L})$

$\operatorname{EcoR} \mathrm{I}(5 \mathrm{U} / \mu \mathrm{L})$

$P s t \mathrm{I}(1,5 \mathrm{U} / \mu \mathrm{L})$

$\operatorname{SmaI}(1,2 \mathrm{U} / \mu \mathrm{L})$

$X b a \mathrm{I}(1,5 \mathrm{U} / \mu \mathrm{L})$

New England Biolabs®:

$\operatorname{EcoR} \mathrm{I}(20 \mathrm{U} / \mu \mathrm{L})$

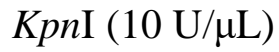

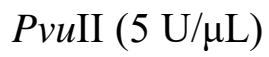

SmaI $(20 \mathrm{U} / \mu \mathrm{L})$

$X b a \mathrm{I}(20 \mathrm{U} / \mu \mathrm{L})$

XhoI $(20 \mathrm{U} / \mu \mathrm{L})$

$X m a I(10 \mathrm{U} / \mu \mathrm{L})$

Promega®:

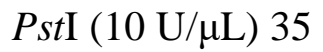




\subsubsection{Outras endonuclease endonucleases}

T4 DNA Ligase ( $1 \mathrm{U} / \boldsymbol{\mu} \mathrm{L})$ (New England Biolabs $\left.{ }^{\circledR}\right)$

3.1.14. Soluções e reagentes para eletroforese em gel de agarose e de poliacrilamida

Tampão de corrida TEB 10X

Trizma base $0,89 \mathrm{M}$

Ácido Bórico 0,89 M

EDTA pH 8,0 0,02 M

$\mathrm{dH}_{2} \mathrm{O}$ q.s.p. $1 \mathrm{~L}$

Tampão de corrida TAE 50X

Tampão Tris-Acetato $2 \mathrm{M}$

Trizma-base $242 \mathrm{~g}$

Ácido Acético Glacial 57,10 mL

EDTA pH 8,0 0,05 M

$\mathrm{dH}_{2} \mathrm{O}$ q.s.p. $1 \mathrm{~L}$

Tampão de amostra para gel de agarose 10X

Tampão de corrida TEB 20X 50\% (v/v)

Glicerol 50\% (v/v)

Azul de Bromofenol 0,1\% (p/v)

Xileno Cianol 0,1\% (p/v)

Solução de brometo de etídeo $20.000 X$

Brometo de etídeo $10 \mathrm{mg} / \mathrm{mL}$ 
3.1.15. Soluções e material para os ensaios imunológicos (ELISA, Western e Dotblot) Tampão de Fosfatasse Alcalina (APB)

Tris-HCl pH 9,5 $100 \mathrm{mM}$

$\mathrm{NaCl} 100 \mathrm{mM}$

$\mathrm{MgCl}_{2} 5 \mathrm{mM}$

Solução de Bloqueio

Leite em pó desnatado $5 \%(\mathrm{p} / \mathrm{v})$

Dissolvido em PBST 1X

\section{Solução Reveladora para ELISA}

pNPP (para-nitro-fenil-fosfato) $1 \mathrm{mg} / \mathrm{mL}$

Dissolvido em APB

\section{Solução Reveladora para Western e Dotblot}

O NBT (Nitro Blue Tetrazole) e o BCIP (5-Bromo-4-Cloro-indolil fosfato) eram preparados numa solução estoque de $50 \mathrm{mg} / \mathrm{mL}$. O NBT solubilizado em N,N-dimetil 38 Formamida e o BCIP , em água. Para preparar $10 \mathrm{~mL}$ da solução reveladora, $66 \mu \mathrm{L}$ do estoque de NBT eram adicionados em $10 \mathrm{~mL}$ de APB e em seguida $33 \mu \mathrm{L}$ do estoque de BCIP. Esta ordem deve ser respeitada para se evitar a precipitação dos reagentes.

\section{Membrana de Nitrocelulose}

Hybond-C Extra (Amersham ${ }^{\circledR}$ Bioscience $n^{\circ}$. Catálogo. RPN 303E)

3.1.16. Placas de microtitulação de poliestireno com 96 poços com fundo chato para ELISA

3.1.17. Resina e coluna para cromatografia de afinidade

(Nunc® Maxisorp, no catálogo: 456537) 


\subsubsection{Marcadores moleculares para DNA e proteína}

1 kbPlus DNA Ladder- (Invitrogen® nº. Catálogo. 10787-026) 39

Fragmentos de DNA em pb: 100; 200; 300; 400; 500; 650; 850; 1.000; 1.650; 2.000; 3.000;

$4.000 ; 5.000 ; 6.000 ; 7.000 ; 8.000 ; 9.000 ; 10.000 ; 11.000 ; 12.000$.

Low Mass DNA Ladder (Invitrogen® nº. catálogo. 10068-013)

Mistura equimolar de fragmentos de DNA em pb de 2.000; 1.200; 800; 400; 200 e 100. Utilizando $2 \mu \mathrm{L}$ do marcador, corresponde a massa de $100 ; 60 ; 40 ; 20 ; 10$ e $5 \mathrm{ng}$, respectivamente.

High Mass DNA Ladder (Invitrogen® ${ }^{\circ}$. catálogo 10496-016)

Mistura equimolar de fragmentos de DNA em pb de 10.000; 6.000; 4.000; 3.000; 2.000 e 1.000. Utilizando $2 \mu \mathrm{L}$ do marcador, corresponde a massa de 100; 60; 40; 30; $20 \mathrm{e}$ $10 \mathrm{ng}$, respectivamente.

BenchMarkTM Pre-stained Protein Ladder Plus (Invitrogen® nº catálogo 10748-010)

Fragmentos de proteínas em kDa: 190; 120; 85; 60; 50; 40; 25; 20, 15 e 10.

\subsubsection{Kits comerciais}

QIAGEN PlasmidMidi Kit (100) - Para preparação plasmidial em escala intermediária (Qiagen®, nº. Catálogo 12145).

QIAGEN Plasmid Maxi Kit (25) - Para preparação plasmidial em larga escala (Qiagen®, $\mathrm{n}^{\mathrm{o}}$. Catálogo 12163).

QIAprep Spin Miniprep Kit (250) - Para preparação plasmidial em pequena escala (Qiagen®, nº. Catálogo 27106). 
Colunas para extração de DNA de gel de agarose por FreezeSqueeze

Ultrafree DA Centrifugal Unit (Millipore®, nº. Catálogo 42600).

3.1.20. Anticorpos utilizados nos ensaios de ELISAt, Dotblot.

Anti-IgG humana $(\mathbf{H}+\mathbf{L})$ feito em cabra $(\mathrm{KPL} \circledast$, no catálogo: 01-10-06)

Concentração: $1 \mathrm{mg} / \mathrm{mL}$

Titulação de uso: 1:1000 (ELISA)

Anti-IgG humana (Fc específico) feito em cabra conjugado com fosfatase alcalina (Sigma®, no catálogo: A9544)

Concentração: $1 \mathrm{mg} / \mathrm{mL}$

Titulação de uso: 1:5000 (ELISA) e 1:2500 (Western blot e Dotblot)

Anti-IgG de camundongo feito em cabra conjugado a FITC (Sigma ${ }^{\circledR}$, no catálogo: F0257)

Concentração: $1 \mathrm{mg} / \mathrm{mL}$

Titulação de uso: 1:100 (FACS)

Anti-IgG humana feito em camundongo conjugado a FITC (BD®, no catálogo: 555786)

Concentração: $1 \mathrm{mg} / \mathrm{mL}$

Titulação de uso: 1:10 (FACS) 


\subsubsection{Oligonucleotídeos utilizados para confirmação das clonagens dos scFvs no vetor de expressão pCOMIRES $\Delta 600$}

Os oligonucleotídeos foram fornecidos pela GenOne e solubilizados em água Milli-Q para concentração de uso de 10 pmoles/ $\mu \mathrm{L}$. A

(Tabela 3) mostra as seqüências de cada um dos oligonucleotídeos.

Tabela 3. Sequências dos oligonucleotídeos utilizados

\begin{tabular}{c|c|c}
\hline Identificação & Seqüência Do Oligonucleotídeo & Utilização \\
\hline VH $X m a$ I & $5^{\prime}$ GGTGTACATTGTGAGCTCGCCCG 3' & $\begin{array}{c}\text { Anela com o início da CDR 1 na região } \\
\text { variável da cadeia pesada (VH) }\end{array}$ \\
\hline VH $X b a$ I & $5^{\prime}$ TGGAACCACCGTGACCGTGT 3' & $\begin{array}{c}\text { Anela com o final da CDR 3 na região } \\
\text { variável da cadeia pesada (VH) }\end{array}$ \\
\hline VL $B g l$ II & 5'CTGGAGGAGGAGGATCAGATC 3' & $\begin{array}{c}\text { Anela com o início da CDR 1 na região } \\
\text { variável da cadeia leve (VL) }\end{array}$ \\
\hline VL Xho I & & $\begin{array}{c}\text { Anela com o final da CDR 3 na região } \\
\text { variável da cadeia leve (VL) }\end{array}$ \\
\hline
\end{tabular}




\subsection{Métodos}

\subsubsection{Preparação de DNA plasmidial.}

\subsubsection{Em pequena escala (adaptado de Sambrook e Russel, 2001).}

1- Aproximadamente $3 \mathrm{~mL}$ de cultura de células de E. coli, transformadas com o plasmídeo de interesse, crescidas em meio LB/Amp $(150 \mu \mathrm{g} / \mathrm{mL})$ durante 16 horas a $37^{\circ} \mathrm{C}$, eram coletados por meio de duas centrifugações de 5 min a $5.000 \mathrm{rpm}$ em microtubos de 1,5mL, sendo o sobrenadante desprezado a cada centrifugação.

2- $\quad$ O sedimento era ressuspendido em $200 \mu \mathrm{L}$ de Solução I. Incubava-se as amostras no gelo por $5 \mathrm{~min}$.

3- $\quad$ Eram adicionados $400 \mu \mathrm{L}$ de Solução II e as amostras eram homogeneizadas, por meio de inversão do tubo várias vezes, e estas eram incubadas à temperatura ambiente por 5 $\min$.

4- Eram adicionados $300 \mu \mathrm{L}$ de Solução III, o mesmo procedimento de homogeneização era repetido, e as amostras eram incubadas no gelo por $10 \mathrm{~min}$.

5- $\quad$ As amostras eram centrifugadas a $12.000 \mathrm{rpm}$ por $15 \mathrm{~min}$ a $4{ }^{\circ} \mathrm{C}$.

6- $\quad$ Ao sobrenadante eram adicionados $5 \mu \mathrm{L}$ de RNAse A e incubava-se por 1 hora a $37^{\circ} \mathrm{C}$.

7- $\quad$ Eram adicionados $300 \mu \mathrm{L}$ de clorofane e, após forte homogeneização, as amostras eram centrifugadas por 5 min a $5.000 \mathrm{~g}$ à temperatura ambiente, a fase aquosa era coletada para outro tubo.

8- Eram adicionados $300 \mu \mathrm{L}$ de clorofil e o mesmo procedimento anterior de homogeneização, centrifugação e coleta eram repetidos 
9- Eram adicionados $2 \mathrm{v}$ de etanol absoluto gelado e as amostras eram incubadas a- $20^{\circ} \mathrm{C}$ por no mínimo 2 horas.

10- As amostras eram centrifugadas a $12.000 \mathrm{rpm}$ por $45 \mathrm{~min}$ a $4^{\circ} \mathrm{C}$. O sobrenadante era desprezado.

11- Era adicionado $1 \mathrm{~mL}$ de etanol $70 \%$ gelado e as amostras eram novamente centrifugadas a $12.000 \mathrm{rpm}$ por $15 \mathrm{~min} \mathrm{a} 4^{\circ} \mathrm{C}$. O sobrenadante era desprezado.

12- O sedimento era seco a vácuo ou por simples exposição ao ar.

13- $\mathrm{O}$ sedimento era ressuspendido em $50 \mu \mathrm{L}$ de $\mathrm{TE}$ e as amostras conservadas a $-20^{\circ} \mathrm{C}$.

\subsubsection{Em larga escala (adaptado de Sambrook e Russel, 2001).}

1- Duzentos ml de cultura de células de E. coli, transformadas com o plasmídeo de interesse, crescidas em meio LB/Amp $(150 \mu \mathrm{g} / \mathrm{mL})$ durante 16 horas a $37^{\circ} \mathrm{C}$, eram coletados por meio de centrifugação de 15 min a 3.000 x $g$, desprezando-se o sobrenadante.

2- O sedimento era ressuspendido em $5 \mathrm{~mL}$ de Solução I sob forte agitação. As amostras eram incubadas no gelo por $10 \mathrm{~min}$.

3- Eram adicionados $10 \mathrm{~mL}$ de Solução II e as amostras eram homogeneizadas, por meio de inversão do tubo várias vezes. Estas eram incubadas à temperatura ambiente por 5 min.

4- Eram adicionados 7,5 mL de Solução III, o mesmo procedimento de homogeneização era repetido, e as amostras eram incubadas no gelo por $10 \mathrm{~min}$.

5- $\quad$ As amostras eram centrifugadas a $10.000 \times g$ por 30 min a $4{ }^{\circ} \mathrm{C}$. 
6- $\quad \mathrm{O}$ sobrenadante era filtrado em papel de filtro e ao sobrenadante eram adicionados $0,6 \mathrm{v}$ de isopropanol. Após uma incubação de 5 min à temperatura ambiente, as amostras eram centrifugadas a $12.000 \times \mathrm{g}$ por $20 \mathrm{~min}$ a temperatura ambiente.

7- $\quad$ O sobrenadante era descartado e, após a secagem por exposição ao ar, o sedimento era ressuspendido em $500 \mu \mathrm{L}$ de TE ao qual eram adicionados $10 \mu \mathrm{L}$ de RNAse A. As amostras eram incubadas por 1 hora a $37^{\circ} \mathrm{C}$.

8- $\quad$ Era adicionado $1 \mathrm{v}$ de clorofane e, após forte homogeneização e centrifugação de 5 $\min$ a $5.000 \mathrm{x} g$ à temperatura ambiente, a fase aquosa era coletada para outro tubo.

9- $\quad$ O passo anterior era repetido mais uma vez. 45

10- Era adicionado então $1 \mathrm{v}$ de clorofil e o mesmo procedimento anterior de homogeneização, centrifugação e coleta eram repetidos

11- Eram adicionados $0,5 \mathrm{v}$ de acetato de amônio $7,5 \mathrm{M}$ e 2,0v de etanol $100 \%$ gelado e as amostras eram incubadas por, no mínimo 2 horas a $-20^{\circ} \mathrm{C}$.

12- As amostras eram centrifugadas a $12.000 \mathrm{rpm}$ por $45 \mathrm{~min}$ a $4{ }^{\circ} \mathrm{C}$. O sobrenadante era desprezado.

13- Era adicionado $1 \mathrm{~mL}$ de etanol $70 \%$ gelado e as amostras eram novamente centrifugadas a $12.000 \mathrm{rpm}$ por $15 \mathrm{~min}$ a $4{ }^{\circ} \mathrm{C}$. O sobrenadante era desprezado.

14- Era adicionado $1 \mathrm{~mL}$ de etanol $70 \%$ gelado e as amostras eram novamente centrifugadas a $12.000 \mathrm{rpm}$ por $15 \mathrm{~min}$ a $4{ }^{\circ} \mathrm{C}$. O sobrenadante era desprezado.

15- O sedimento era seco a vácuo ou por simples exposição ao ar.

16- $\quad$ O sedimento era ressuspendido em $200 \mu \mathrm{L}$ de TE. E as amostras conservadas a -20 ${ }^{\circ} \mathrm{C}$. 


\subsubsection{Digestão de DNA plasmideal com endonucleases de restrição}

As digestões dos plasmídeos foram realizadas com endonucleases de restrição conforme instruções dos fabricantes. O tempo de incubação e a quantidade de material a ser digerido variavam de acordo com o interesse do experimento realizado.

\subsubsection{Análise de DNA plasmideal em gel de agarose (Sambrook e Russel, 2001).}

A agarose foi preparada numa concentração de 0,7 a 1,0\% em tampão TEB $1 \mathrm{X}$ ou TAE $1 \mathrm{X}$ com $0,5 \mu \mathrm{g} / \mathrm{mL}$ de brometo de etídeo. As Amostras de DNA eram aplicadas com tampão de amostra para gel de agarose no gel e eram submetidas à eletroforese em tampão TEB ou TAE 0,5X, como descrito por (Sambrook e Russel, 2001). Para visualização do DNA luz ultravioleta eram incididas no gel utilizando um transluminador (Pharmacia-LKB®) e a imagem era digitalizada em fotodocumentador.

\subsubsection{Eluição de fragmentos de DNA de gel de agarose}

Após eletroforese os fragmentos de DNA a serem eluídos foram cortados do gel de agarose. A eluição do DNA do gel submetendo-o ao Freeze-Squeze:

1- A banda do gel contendo o DNA era cortada e transferida para uma bolsa feita utilizando um pedaço de Parafilm. As duas extremidades da bolsa eram reunidas e seladas com o auxílio da parte cônica de um microtubo de $1,5 \mathrm{~mL}$. A banda era inserida dentro da bolsa pela parte não selada.

2- A bolsa contendo o fragmento era congelada a $-40{ }^{\circ} \mathrm{C}$.

3- $\quad$ Após o total congelamento, a porção plana da tampa de um microtubo de $1,5 \mathrm{~mL}$ era utilizada para macerar o fragmento até se liquefazer.

4- O líquido e o gel eram transferidos para colunas Ultrafree DA Centrifugal Unit (Millipore ${ }^{\circledR}$ ). 
5- $\quad$ O material era centrifugado por 5 min a $12.000 \mathrm{x}$ g a temperatura ambiente.

6- Após a centrifugação o material era precipitado com a adição de $0,1 \mathrm{v}$ de acetato de sódio 3M, $60 \mu \mathrm{g}$ de glicogênio e 2,5v etanol 100\% gelado. As amostras eram incubadas a $20{ }^{\circ} \mathrm{C}$ durante a noite para um melhor rendimento da precipitação.

\subsubsection{Reação de Desfosforilação com a fosfatase alcalina de camarão (SAP)}

Esta endonuclease tem a capacidade de remover o grupo fosfato presente nas extremidades5 de dsDNA digeridos com endonucleases de restrição. Dessa forma, ela impede uma auto-ligaçãodo DNA plasmidial digerido sem a inserção do inserto.

1- Dois a quatro $\mu \mathrm{g}$ de dsDNA eram incubados com $5 \mu \mathrm{L}$ da fosfatase alcalina e tampão o apropriado da endonuclease em $1 \mathrm{X}$ para um volume final de $50 \mu \mathrm{L}$ por $1 \mathrm{~h}$ a $37^{\circ} \mathrm{C}$

2- $\quad$ O sistema era inativado por 15 minutos a $65^{\circ} \mathrm{C}$. A partir desse ponto, o sistema era utilizado em sistema de ligação para posterior transformação de células competentes $E$. Coli.

\subsubsection{Ligação de fragmentos de DNA}

As concentrações de DNA (vetor e inserto) utilizadas nos sistemas de ligação variaram de acordo com o experimento, sendo normalmente uma razão molar que variou de 1:1 a 1:5, aplicando-se a seguinte fórmula:

$$
\frac{\text { ng vetor } \mathrm{x} \text { tamanho do inserto em pb }}{\text { Tamanho do vetor em } \mathrm{pb}} \times \frac{\text { razão inserto }}{\text { vetor }}=\text { ng de inserto }
$$

A reação de ligação foi realizada de acordo com instrução do fabricante a incubação foi feita durante 16 horas à $37^{\circ} \mathrm{C}$.

Após esta fase da ligação, os sistemas foram transformados em células competentes de E. Coli. Por eletroporação. 


\subsubsection{Preparação de células competentes e transformação bacteriana.}

\subsubsection{Por choque térmico- $\mathrm{CaCl}_{2}$ (adaptado de Maranhão, 2003).}

Eram inoculados $500 \mu \mathrm{L}$ de um pré-inóculo, feito a partir de uma colônia isolada da célula de interesse, em $50 \mathrm{~mL}$ de meio LB. O inóculo era incubado a $37^{\circ} \mathrm{C}$ a $220 \mathrm{rpm}$ até a cultura atingir uma densidade óptica a 600nm (OD600) de 0,1 a 0,3.

1- O inóculo era centrifugado a 3.000 x $g$ por $15 \mathrm{~min}$ a $4{ }^{\circ} \mathrm{C}$, o sobrenadante era desprezado. (Após essa etapa é importante que em todas as etapas subsequentes as células sejam mantidas resfriadas para evitar uma perda de eficiência).

2- O sedimento era ressuspendido em $10 \mathrm{~mL}$ de solução de $\mathrm{CaCl} 250 \mathrm{mM}$ estéril gelada, com movimentos suaves.

3- $\quad$ Era feita uma centrifugação a 3.000 x $g$ por 15 min a $4{ }^{\circ} \mathrm{C}$, o sobrenadante era desprezado.

4- $\mathrm{O}$ sedimento era ressuspendido em $1 \mathrm{~mL}$ de solução de $\mathrm{CaCl} 250 \mathrm{mM}$ estéril gelada, com movimentos suaves.

5- $\quad$ Após incubação de 1 hora em banho de água/gelo, as células eram aliquotadas e estas podiam ser utilizadas por um período máximo de 24 horas.

6- Eram incubados de 100 a $200 \mu \mathrm{L}$ de célula competente com o plasmídio de interesse a ser transformado em banho de água/gelo por $30 \mathrm{~min}$.

7- $\quad$ O choque térmico era realizado por meio de incubação do sistema de transformação em banho a $42{ }^{\circ} \mathrm{C}$ por $3 \mathrm{~min}$. 
8- $\quad$ Era adicionado imediatamente $1 \mathrm{~mL}$ de meio LB e o sistema era incubado por $1 \mathrm{~h}$ a $37^{\circ} \mathrm{C}$.

9- Eram semeadas quantidades variáveis do sistema de transformação em placas contendo meio LB-ágar contendo ampicilina a $150 \mu \mathrm{g} / \mathrm{mL}$. As placas eram mantidas na estufa a $37^{\circ} \mathrm{C}$ por 16 horas.

\subsubsection{Por eletroporação (adaptado de Maranhão, 2003).}

1- Uma colônia isolada da célula de interesse era inoculada em $10 \mathrm{~mL}$ de meio SB contendo o antibiótico de interesse. Esse pré-inóculo era mantido a $37^{\circ} \mathrm{C}$ sob agitação de 220 rpm por 16 horas.

2- $\quad$ Era inoculado $1 \mathrm{~mL}$ do pré-inóculo em $500 \mathrm{~mL}$ de meio $\mathrm{SB}$ contendo $2,5 \mathrm{~mL}$ da solução estoque de glicose $2 \mathrm{M}$ e $2,5 \mathrm{~mL}$ da solução estoque de $\mathrm{Mg} 2 \mathrm{M}$. O inoculo era incubado a $37^{\circ} \mathrm{C}$ a 220 rpm até a cultura atingir uma OD600 de 0,7 a 0,9.

3- $\quad \mathrm{O}$ inoculo era centrifugado a $3.000 \times \mathrm{g}$ por 20 min a $4{ }^{\circ} \mathrm{C}$, o sobrenadante era desprezado e a célula era mantida sempre gelada a partir desse momento.

4- $\quad \mathrm{O}$ sedimento era ressuspendido em $25 \mathrm{~mL}$ de glicerol $10 \%$ estéril gelado e a seguir eram adicionados mais $75 \mathrm{~mL}$ de glicerol $10 \%$ gelado.

5- $\quad$ Era feita outra centrifugação a 3.000 x $g$ por 20 min a $4{ }^{\circ} \mathrm{C}$, repetindo a etapa anterior.

6- $\quad$ O sedimento era ressuspendido em $25 \mathrm{~mL}$ de Gilcerol 10\% estéril gelado e submetido a última centrifugação a $3.000 \times \mathrm{g}$ por $20 \mathrm{~min}$ a $4{ }^{\circ} \mathrm{C}$.

7- $\quad$ O sedimento final era ressuspendido em 1 a $2 \mathrm{~mL}$ de glicerol $10 \%$ e as células eram aliquotadas, congeladas em banho de gelo seco com etanol e armazenadas imediatamente a $80^{\circ} \mathrm{C} .48$ 
8- Para a transformação, o plasmídeo era adicionado, já em um tubo resfriado

previamente, à célula competente e imediatamente colocado na cubeta de eletroporação (BioAgency®) também já resfriada.

9- A eletroporação era feita seguindo os seguintes parâmetros elétricos: $2,5 \mathrm{kV}, 25 \mu \mathrm{F}$ e $200 \Omega$, no aparelho Gene Pulser com PulserController da BioRad. O $\tau$ esperado nessas condições é de 4,0 a 5,0 milissegundos.

10- Imediatamente após o choque a cubeta era lavada com $3 \mathrm{~mL}$ de meio $\mathrm{SOC}$ e o meio era recolhido para um tubo de centrifugação de $50 \mathrm{~mL}$.

11- Após uma incubação de $1 \mathrm{~h}$ a $37^{\circ} \mathrm{C}$ e $220 \mathrm{rpm}$, diluições da transformação eram semeadas em placas contendo ampicilina a $200 \mu \mathrm{g} / \mathrm{mL}$. As placas eram mantidas na estufa a $37^{\circ} \mathrm{C}$ por 16 horas.

\subsubsection{Condições e preparo da Reação em Cadeia da Polimerase (PCR)}

Os oligonucleotídeos com as seqüências controles e indutoras estão listados em materiais e métodos. A reação em cadeia da polimerase foi realizada com a enzima Taq DNA Polymerase 100U da Invitrogen (Número de catálogo 18038-018). 
Tabela 3: Condições da PCR

\begin{tabular}{|c|c|c|}
\hline Reação & Temperatura & Tempo \\
\hline 1- Temperatura de Desnaturação & $95^{\circ} \mathrm{C}$ & $5 \mathrm{~min}$. \\
\hline 2- Temperatura de Desnaturação & $95^{\circ} \mathrm{C}$ & $1 \mathrm{~min}$. \\
\hline 3-Temperatura de Anelamento & $55^{\circ} \mathrm{C}$ & $1 \mathrm{~min}$. \\
\hline 4 -Temperatura de Extensão & $72{ }^{\circ} \mathrm{C}$ & $1 \mathrm{~min}$. \\
\hline \multicolumn{3}{|c|}{ Repetiu-se 29 vezes a partir do 2} \\
\hline 6- Temperatura de Extensão & $72{ }^{\circ} \mathrm{C}$ & $5 \mathrm{~min}$. \\
\hline 7- End. & $4{ }^{\circ} \mathrm{C}$ & - \\
\hline
\end{tabular}




\begin{tabular}{|c|c|c|c|c|c|c|c|c|}
\hline $10 \mathrm{ng}$ & $\begin{array}{l}\text { Primer } \\
\mathbf{5}, \\
\text { Хma I } \\
10 \mathrm{uM}\end{array}$ & $\begin{array}{l}\text { Primer } \\
\mathbf{3}^{\prime} \\
\text { Xba I } \\
10 \mathrm{uM}\end{array}$ & $10 \mathrm{mM}$ & 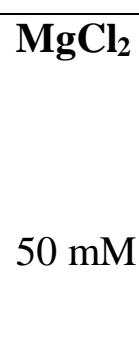 & $\begin{array}{l}\text { Buffer } \\
\text { Taq. } \\
10 \mathrm{x}\end{array}$ & $1 \mathrm{uL}$ & Milli $Q$ & Vol.Tota \\
\hline $1 \mathrm{uL}$ & $3 \mathrm{uL}$ & - & $5 \mathrm{uL}$ & $2 \mathrm{uL}$ & $5 \mathrm{uL}$ & $1 \mathrm{uL}$ & $34 \mathrm{uL}$ & $50 \mathrm{uL}$ \\
\hline $1 \mathrm{uL}$ & - & $3 \mathrm{uL}$ & $5 \mathrm{uL}$ & $2 \mathrm{uL}$ & $5 \mathrm{uL}$ & $1 \mathrm{uL}$ & $34 \mathrm{uL}$ & $50 \mathrm{uL}$ \\
\hline $1 \mathrm{uL}$ & $3 \mathrm{uL}$ & $3 \mathrm{uL}$ & $5 \mathrm{uL}$ & $2 \mathrm{uL}$ & $5 \mathrm{uL}$ & $1 \mathrm{uL}$ & $31 \mathrm{uL}$ & $50 \mathrm{uL}$ \\
\hline
\end{tabular}

\begin{tabular}{|c|c|c|c|c|c|c|c|c|}
\hline $10 \mathrm{ng}$ & $\begin{array}{l}\text { Primer } \\
\text { 5, } \\
B g l \mathrm{II} \\
10 \mathrm{uM}\end{array}$ & $\begin{array}{l}\text { Primer } \\
\text { 3' } \\
\text { Xho I } \\
10 \mathrm{uM}\end{array}$ & dNTP & $\mathrm{MgCl}_{2}$ & $\begin{array}{l}\text { Buffer } \\
\text { Taq. } \\
10 \mathrm{x}\end{array}$ & Taq. & Milli $Q$ & Vol.Total \\
\hline $1 \mathrm{uL}$ & $3 \mathrm{uL}$ & - & $5 \mathrm{uL}$ & $2 \mathrm{uL}$ & $5 \mathrm{uL}$ & $1 \mathrm{uL}$ & $34 \mathrm{uL}$ & $50 \mathrm{uL}$ \\
\hline $1 \mathrm{uL}$ & - & $3 \mathrm{uL}$ & $5 \mathrm{uL}$ & $2 \mathrm{uL}$ & $5 \mathrm{uL}$ & $1 \mathrm{uL}$ & $34 \mathrm{uL}$ & $50 \mathrm{uL}$ \\
\hline $1 \mathrm{uL}$ & $3 \mathrm{uL}$ & $3 \mathrm{uL}$ & $5 \mathrm{uL}$ & $2 \mathrm{uL}$ & $5 \mathrm{uL}$ & $1 \mathrm{uL}$ & $31 \mathrm{uL}$ & $50 \mathrm{uL}$ \\
\hline
\end{tabular}

\subsubsection{Cultura de células de mamíferos}

Durante toda a manutenção da cultura, as células eram observadas em microscópio invertido Leica DMIL e incubava-se em estufa a 37 oC, $5 \%$ de CO2 e $70 \%$ de umidade. 


\subsection{Congelamento de células de mamíferos - Criopreservação (Ruggiero, 2002).}

As células em cultura aderente eram lavadas 3 vezes. Após esse procedimento, eram adicionados $5 \mathrm{~mL}$ de tripsina para que as células se soltassem da garrafa de cultura.

1- A suspensão celular era então transferida para um tubo de centrifuga de $50 \mathrm{~mL}$, ao

qual eram acionados $5 \mathrm{~mL}$ de meio Ham-F12 acrescido de $10 \%$ de soro fetal bovino (SFB), para a inativação da tripsina que é nociva as células.

2- $\quad$ As células eram centrifugadas a 130 x $g$ por $8 \mathrm{~min}$.

3- $\quad$ O sobrenadante era descartado e o sedimento era ressuspendido no meio de cultura remanescente do tubo.

4- As células eram distribuídas em alíquotas de $500 \mu \mathrm{L}$ em criotubos, onde $500 \mu \mathrm{L}$ de meio de congelamento eram adicionados

5- Os criotubos eram incubados a $4^{\circ} \mathrm{C}$ por $30 \mathrm{~min}$, depois a $-20^{\circ} \mathrm{C}$ por 30 min e depois $\mathrm{a}-80^{\circ} \mathrm{C}$ durante a noite. As células poderiam permanecer estocadas a esta temperatura ou ser transferidas para a estocagem em nitrogênio líquido.

\subsection{Descongelamento de células de mamíferos (Ruggiero, 2002).}

1. Os criotubos eram transferidos para um banho de $37^{\circ} \mathrm{C}$ até o total descongelamento das células.

2. As células eram plaqueadas em densidade de 2 x 102 células por garrafa de $25 \mathrm{~cm} 2$ em meio Ham-F12 acrescido de 10\% SFB. 
3.2.13.1.3. Tripsinização, passagem das células e formação de monocamada celular (Ruggiero, 2002).

Quando as células atingiam a confluência total e cobriam $100 \%$ de toda superfície da placa de cultura, elas deveriam ser repicadas.

1- O meio de cultura da garrafa era descartado.

2- $\quad$ Eram adicionados à garrafa $5 \mathrm{~mL}$ de tripsina numa concentração de 1:250.

3- $\quad$ Após $3 \mathrm{~min}$, as células começaram a se descolar da superfície da garrafa. O descolamento das células era acompanhado por visualização a olho nu. 50

4- $\quad$ A tripsina era neutralizada com cerca de $5 \mathrm{~mL}$ de meio acrescido de $10 \%$ de SFB.

5- A suspensão celular era transferida para tubos falcon de $50 \mathrm{~mL}$, e centrifugados a 130 $\mathrm{x} g$ por 8 min.

6- $\quad$ O sobrenadante era descartado e o sedimento ressuspenso em $3 \mathrm{~mL}$ de meio acrescido de SFB.

7- Era transferida toda a população células por garrafas de $75 \mathrm{~cm}^{2}$ ou $150 \mathrm{~cm}^{2}$ contendo $10 \mathrm{~mL}$ ou $30 \mathrm{~mL}$ de meio acrescido de SFB.

\subsection{Estimativa do número de células por meio de contagem em câmara de Neubauer (adaptado de Spectoret al., 1998).}

1- $\quad$ As células eram tripsinizadas e ressuspensas em $1 \mathrm{~mL}$ de meio de cultura.

2- A câmara de Neubauer era coberta com a lamínula e eram aplicados $10 \mu \mathrm{L}$ de suspensão de células em cada compartimento da Câmara. Caso alguma diluição tivesse sido necessária, o número de células contado era multiplicado por esse fator de diluição. 
3- As células eram observadas em microscópio óptico (na objetiva com aumento de 40 vezes) e contadas nos quadrantes. Em seguida, era utilizada a fórmula:

Número de células contadas X fator de diluição X $10^{4}=\mathrm{n}^{\circ}$ de células $/ \mathrm{mL}$ Número de quadrantes contados

\subsection{Determinação Viabilidade celular (adaptado de Spectoret al., 1998).}

1- As células eram tripsinizadas e transferidas para um tubo Falcon de $15 \mathrm{~mL}$, ao qual se adicionou $5 \mathrm{~mL}$ de meio com SFB.

2- $\quad$ As células eram centrifugadas a $130 \times \mathrm{g}$ por $8 \mathrm{~min}$.

3- $\quad \mathrm{O}$ sobrenadante era descartado e as células ressuspensas em $3 \mathrm{~mL}$ de meio de cultura remanescente.

4- Vinte microlitros da suspensão celular eram incubados com $80 \mu \mathrm{L}$ da solução de Azul de Tripan (diluição de 5 vezes da cultura).

5- A câmara de Neubauer era montada, e nela aplicou-se um volume de $10 \mu \mathrm{L}$ da mistura.

6- $\quad$ Eram contadas 200 células, entre viáveis (transparentes) e não-viáveis (azuis). A célula não-viável tem a membrana celular mais permeável, e por isso, o corante entra na célula, tornando-a azul. Após a contagem, era estabelecida a porcentagem de células viáveis.

\subsubsection{Transfecção de células CHO-K1 e HEK-293 utilizando o reagente JetPEI $^{\mathrm{TM}}$ (PolyplusTransfection, $\mathrm{n}^{0}$ de catálogo 101-01N).}

1- Em uma placa de cultura de 6 poços eram semeadas cerca de 4,2 x 105 células por poço, e em seguida eram adicionados $2 \mathrm{~mL}$ de meio contendo SFB. 
2- $\quad$ As células eram incubadas em estufa a $37^{\circ} \mathrm{C}, 5 \%$ de $\mathrm{CO} 2$ e $70 \%$ de umidade durante a noite, até que se atingisse a confluência de $90 \%$.

3- No dia seguinte, o DNA a ser transfectado era diluído em meio de cultura sem soro. Para placas de 6 poços, a quantidade a ser utilizada é: $2,5 \mu \mathrm{g}$ de DNA por poço, para um volume final de $500 \mu \mathrm{L}$, completado com meio sem soro.

4- $\quad$ Era adicionado o reagente Jet prime á solução de DNA. Para placas de 6 poços, a quantidade do reagente a ser utilizada é $6,25 \mu \mathrm{L}$.

5- $\quad$ A solução era incubada por 30 min à temperatura ambiente.

6- Enquanto o complexo era formado, o meio dos poços do dia anterior era trocado por $2 \mathrm{~mL}$ de meio sem soro.

7- $\quad$ Após este período, a mistura era adicionada lentamente sobre o poço em movimentos cruciformes (no total, foram adicionados $500 \mu \mathrm{L}$ da mistura por poço).

8- $\quad$ As células eram incubadas a $37^{\circ} \mathrm{C}$ com $5 \%$ de $\mathrm{CO}^{2}$ e $70 \%$ de umidade.

9- Transcorridas de 4 a 6 horas após a transfecção, o meio de cultura sem soro era trocado para um meio de cultura com soro. Em seguida, a placa era incubada durante a noite nas mesmas condições descritas no passo 7 .

10- No tempo de 48 e 72 horas pós-transfecção, o meio de cultura era coletado e verificava-se a presença dos anticorpos recombinantes.

\subsubsection{Seleção de células transfectadas utilizando Geneticina® (G418-Sulfato)}

Como a construção bicistrônica (pCO 600) utilizada para expressão dos anticorpos recombinantes apresentam o gene de resistência a geneticina $\left(\mathrm{NEO}^{\mathrm{R}}\right)$, após o processo de transfecção os vetores possibilitaram que fosse feita a seleção das células transfectadas e eliminação daquelas que não estavam produzindo as proteínas recombinantes. 
1- Após $72 \mathrm{~h}$ da transfecção o sobrenadante de cultura era coletado para verificação da expressão de proteínas recombinantes e o meio era reposto adicionado de geneticina a uma concentração final de $600 \mu \mathrm{g} / \mathrm{mL}$ em todos os poços transfectados com o plasmídio e também no poço com as células não transfectadas, utilizadas como controle.

2- $\quad$ O meio de cultura a partir de então era trocado a cada $48 \mathrm{~h}$ nas mesmas condições descritas anteriormente e visualizava-se, ao microscópio ótico, a morte celular no poço controle de células não transfectadas.

3- Quando era constatado que houve a morte das células não transfectadas (elas mudam sua morfologia de elípticas para esféricas e perdem a aderência à placa de cultura) permanecia-se mais uma semana com o procedimento descrito acima e a partir de então as células eram consideradas selecionadas e somente células transfectadas estavam presentes no poço.

\subsubsection{Propagação das células transfectadas selecionadas para aumento da expressão.}

1- Quando as células transfectadas selecionadas atingiam a confluência máxima no poço era então procedido à propagação das células para aumento da cultura e consequentemente da quantidade de proteína recombinante expressa.

2- $\quad$ O meio de cultura do poço era descartado.

3- $\quad$ Eram adicionados $500 \mu \mathrm{L}$ de tripsina ao poço.

4- Após $3 \mathrm{~min}$, as células começaram a se descolar da superfície da garrafa. $\mathrm{O}$ descolamento das células era acompanhado por visualização a olho nu.

5- A tripsina era neutralizada com cerca de $1 \mathrm{~mL}$ de meio acrescido de $10 \%$ SFB. 
6- $\quad$ A suspensão celular era transferida para tubos falcon de $15 \mathrm{~mL}$, e centrifugados a 130 $\mathrm{x} g$ por $8 \mathrm{~min}$.

7- $\quad$ O sobrenadante era descartado e o sedimento ressuspenso em $3 \mathrm{~mL}$ de meio HamF12 acrecido de SFB.

8- Transferia-se toda a população células para garrafas de $75 \mathrm{~cm}^{2}$ contendo $10 \mathrm{~mL}$ de meio Ham-F12 acrescido de 10\% SFB e geneticina na concentração já citada.

9- Quando as células chegavam novamente a uma confluência máxima as células eram então passadas para garrafas de $150 \mathrm{~cm}^{2}$ contendo $30 \mathrm{~mL}$ de meio Ham-F12 acrescido de 10\% SFB e geneticina. A partir de então, as células transfectadas eram mantidas nessas condições, trocando-se o meio a cada 7 dias nas mesmas condições e coletando-se o sobrenadante para o acumulo de quantidade suficiente para purificação dos anticorpos recombinantes e realização dos ensaios biológicos.

\subsubsection{ELISA (Enzyme-linked immunosorbent assay).}

Eram realizados ensaios do tipo ELISA sanduíche para detecção e quantificação das proteínas recombinantes.A detecção da proteína recombinante foi feita pela porção Fc humana, tendo sido sensibilizada a placa com um anticorpo anti-IgG humana que reconhece a porção Fc. A revelação foi feita com um segundo anticorpo anti- IgG humana conjugado à fosfatasse alcalina Após cada lavagem as placas de microtitulação (Nunc®) eram invertidas sobre uma pilha de papel toalha $\mathrm{E}$ batidas vigorosamente até a retirada completa das soluções presentes. Durante as incubações as placas permaneciam fechadas para evitar a evaporação das soluções. Os anticorpos utilizados estão detalhados no tópico 3.1.23 do Material.

1- Os poços de interesse na placa eram sensibilizados com $150 \mu \mathrm{L}$ por poço com o anticorpo anti-IgG humana $\mathrm{H}+\mathrm{L}$ feito em cabra, diluído em PBS 1X 1:1.000, e eram lincubados durante 1 hora a temperatura ambiente. 
2- $\quad$ Os poços eram lavados $3 \mathrm{X}$ com PBST $1 \mathrm{X}, 200 \mu \mathrm{L}$ por poço.

3- $\quad$ Os poços eram bloqueados com $180 \mu \mathrm{L}$ por poço de solução de bloqueio, e eram incubados durante 1 hora a temperatura ambiente ou durante a noite a $4^{\circ} \mathrm{C}$.

4- Estes eram lavados $3 \mathrm{X}$ com PBST $1 \mathrm{X}$ e o sobrenadante de cultura das células transfectadas eram adicionados. Eram feitas diluições seriadas de fator comum 3 dos anticprpos em PBS, onde o volume final era de $100 \mu \mathrm{L}$ por poço e títulos de 1:1; 1:3; 1:9; 1:27; 1:81 e 1:243. A mesma diluição era realizada para todas as amostras. Como padrão utilizava-se IgG humana purificada na concentração especificada no material (diluída na mesma solução/meio que as proteínas recombinantes). As reações eram feitas em triplicatas e eram incubadas por 1 hora a temperatura ambiente.

5- Os poços foram lavados novamente $3 \mathrm{X}$ com PBST $1 \mathrm{X}$ e $150 \mu \mathrm{L}$ por poço do anticorpo anti-Fc humano conjugado a fosfatase alcalina feito em cabra na diluição de 1:5.000 eram incubados por 1 hora a temperatura ambiente.

6- $\quad$ Os poços eram lavados $3 \mathrm{X}$ com $\mathrm{PBST} 1 \mathrm{X}$ e uma vez com tampão para fosfatasse alcalina (APB).

7- $\quad$ O ensaio era revelado com $100 \mu \mathrm{L}$ por poço de pNPP (para-nitro-fenil-fosfato) 1 $\mathrm{mg} / \mathrm{mL}$ dissolvido em APB. Este era incubado por 20 a $30 \mathrm{~min}$ a temperaturta ambiente. A partir daí a absorbância era lida no leitor de ELISA —Microplate Reader BioRad®\| modelo $450 \mathrm{a} \mathrm{nm}$ a um comprimento de onda de $405 \mathrm{~nm}$. Eram considerados os valores do controle com PBS e os valores da curva padrão para realizar os cálculos das concentrações dos sobrenadantes. 
3.2.15. Purificação de Proteínas com a coluna ImmunoPure Plus Immobilized Protein A (Pierce $\left.{ }^{\circledR}\right)$ e concentração das amostras eluídas com a coluna Centricon da Millipore.

1- Primeiramente foi montada a bomba peristáltica para ser utilizada com a coluna.

2- $\quad$ Desempacotou-se a resina na coluna, e depois colocou- se a coluna em posição Vertical até que ela voltasse a ficar empacotada.

3- $\quad$ Abriu- se a mangueira da bomba peristáltica e filtrou- se $10 \mathrm{~mL}$ de Biding Buffer.

4- $\quad$ Posteriormente, foi colocado o sobrenadante diluído na proporção de 1:1 com Biding Buffer

5- $\quad$ Assim que todo o sobrenadante foi passado pela coluna, colocou-se $30 \mathrm{~mL}$ de Biding Buffer.

6- $\quad$ Após a passagem dos $30 \mathrm{~mL}$, foi colocado $20 \mathrm{~mL}$ de Elution Buffer.

7- $\quad$ A eluição foi coletada em 20 microtubos.

8- $\quad$ Depois foram passados mais $10 \mathrm{~mL}$ de Biding Buffer na coluna.

9- $\quad$ Após este processo a coluna foi lavada com água Milli Q. com azida sódica a 0,5\%.

10- Posteriormente foram feitas análises por Dot Blot das frações eluídas da coluna.

11- Procedeu- se a concentrão das amostras com a coluna Centricon da Millipore.

12- A coluna foi centrifugada a $7.500 \mathrm{~g}$ por 10 minutos com tampão PBS.

13- Depois ineverteu- se a coluna e colocou- se as amostras diluídas 1:1 com tampão PBS.

14- Centrifugou- se a 7.500 g por 10 minutos com tampão PBS.

15- Coletou- se as amostras em microtubos. 


\subsubsection{Análise de proteínas em gel de poliacrilamida desnaturante (adaptado de Silva-} Pereira, 2003).

A eletroforese unidimensional em gel SDS- PAGE (SDS- PAGE: Sodium Dodecyl Sulphate- Polyacrilamide Gel Eletrophoresis) foi utilizada para determinar a massa molecular dos FvFcs recombinantes após as etapas de purificação. Foram preparados dois géis SDSPAGE, um foi corado com a coloração de prata, e o outro foi transferido para uma membrana de nitrocelulose para ser feito o Western- Blot.

1- Primeiramente foi montado o aparato de eletroforese: limpeza das placas, montagem das placas com os espaçadores laterais.

2- Preparou- se a solução do gel separador na concentração de $12 \%$ de policacrilamida (proporcional a $55 \mathrm{kDa}$ ), removeu- se bolhas com butanou e depois lavou- se o gel com água Milli Q.

3- $\quad$ Mante - se a placa em posição vertical, até que a polimerização do gel terminasse.

4- Preparou- se a solução com o gel concentrador, vertendo sobre o gel separador e, introduzindo o pente para a formação de poços.

5- $\quad$ Após a polimerização do gel concentrador, removeu- se o pente.

6- Posteriormente as amostras foram preparadas: adicionou- se o tampão de amostras contendo $\beta$ - mercaptoetanol $4 \%$, e depois cada amostra foi fervida a $100^{\circ} \mathrm{C}$ durante 5 minutos.

7- $\quad$ As amostras foram aplicadas nos poços com os marcadores. Descritos em materiais.

8- $\quad$ As condições de migração do gel foram: $20 \mathrm{~mA}$, voltagem $300 \mathrm{~V}$ durante 4 horas. 


\section{Coloração do gel SDS- PAGE com o kit comercial Proteo Silver Stain da Sigma.}

1- $\quad$ Após a eletroforese o gel SDS- PAGE foi fixado por 40 minutos com a solução de fixação em uma placa de petri de vidro;

2- $\quad$ Depois a solução de fixação foi desprezada e o gel foi lavado com $100 \mathrm{~mL}$ de etanol $30 \%$ por 10 minutos.

3- $\quad$ Lavou- se o gel com 100mL de água Milli Q.

4- Incubou- se o gel com a solução de sensibilização por 10 minutos.

5- $\quad$ Depois a solução de sensibilização foi desprezada e colocou- se $100 \mathrm{~mL}$ da solução equilibrada com prata, por 10 minutos.

6- $\quad$ Desprezou- se a solução e incubou- se com água Milli Q. por 1 minuto.

7- $\quad$ Depois a água foi desprezada e incubou- se o gel com a solução reveladora por 10 minutos.

8- $\quad$ Após o aparecimento das bandas do gel SDS- PAGE, adicionou- se $5 \mathrm{~mL}$ da solução Stop Protein Silver.

9- Depois a solução foi desprezada e o gel foi armazenado com água Milli Q.

\subsubsection{Eletroforese em Gel através de Microchip (Método GelChip-CE)}

A separação, deteç̧ão e quantificação das amostras contidas nas alíquotas de cultura induzida também foram realizadas no instrumento Agilent 2100 Bioanalyzer método GelChip-CE (Agilent Technologies, Waldbronn, Germany) em combinação com o kit Protein 200 plus LabChip e o software Protein 200 Plus (version A.02.12).

1- A preparação (priming) e o preenchimento dos microchips com as amostras foram realizados de acordo com o protocolo do kit Protein 200 Plus LabChip como recomendado pelo fabricante. 
2- 16 poços interconectados via rede de microcanais, que foram preenchidos com uma mistura de corante e gel da seguinte maneira:

3- Quatro reservatórios com a mistura gel-corante um com a solução descorante (destaining solution), um com o padrão de tamanho molecular (ladder).

4- Os microcanais foram preenchidos pipetando-se $12 \mu \mathrm{L}$ da mistura gel-corante dentro dos reservatórios apropriados. A mistura foi inserida dentro dos microcanais aplicando-se uma pressão ao reservatório adequado via seringa de $1 \mathrm{~mL}$. Os microchips recentemente preparados (priming) foram utilizados imediatamente. Três reservatórios adicionais para tampão foram preenchidos com $12 \mu \mathrm{L}$ da mistura gel-corante.

5- $\quad$ As amostras foram desnaturadas misturando-se estas com tampão de amostra (buffer proporcionado pelo kit) na proporção 2:1 e aquecidas em banho de água fervente por 3 min. O tampão de amostra fornecido com o kit Agilent Protein 200 plus Assay continha 4 \% SDS, um corante fluorescente apropriado, e duas proteínas controle de tamanho conhecido servindo como marcadores internos de tamanho.

6- Após a etapa de desnaturação, as amostra foram inseridas no microchip. Os reservatórios das amostras e do padrão foram preenchidos com as soluções apropriadas. O microchip foi agitado em um agitador tipo vortex e inserido dentro do instrumento Bioanalyzer para análise.

\subsubsection{Análise das proteínas recombinantes por Western Blot. (Adaptado de Brígido, 2003).}

Após realizada a corrida do gel SDS- PAGE, um dos géis preparados no item 3.2.20, foi transferido para uma membrana da nitrocelulose.

1- Foram cortados 12 pedaços de papel filtro Whatmam e uma pedaço de membrana de nitrocelulose (todos do tamanho do gel que foi transferido). 
2- $\quad$ A membrana de nitrocelulose e os papeis filtros, foram molhados com o tampão de transferência.

3- $\quad$ Montou-se um sanduíche com os papeis filtros e a membrana de nitrocelulose com o gel no meio. E colocou- se sobre o eletrodo de grafite.

4- A transferência do gel procedeu- se com $80 \mathrm{~mA}, 10 \mathrm{~V}$, por cerca de duas horas.

5- Após o gel ser transferido para a membrana de nitrocelulose, a membrana foi incubada por 2 horas com a solução bloqueio (PBS com 5\% de leite em pó Molico).

6- $\quad$ A membrana de nitrocelulose foi lavada com PBST por 3 vezes.

7- $\quad$ Após as lavagens, incubou- se por 2 horas o anticorpo conjugado com fosfatase alcalina, F(ab')2-Goat anti-Human IgG Fc.

8- $\quad$ Depois foram feitas 3 lavagens com PBST.

9- $\quad$ Após as lavagens adicionou- se a solução reveladora Immun-Blot ${ }^{\circledR}$ Opti-4CN ${ }^{\mathrm{TM}}$ da Bio rad. 


\section{RESULTADOS E DISCUSSÃO}

\subsection{Humanização}

Como a maioria dos MAbs disponíveis no mercado são de origem murino, eles são naturalmente antigênicos em humanos, dando origem a uma resposta imunitária indesejável chamada resposta HAMA. A utilização de MAbs murino como agentes terapêuticos em humanos é limitada pelo fato do paciente poder desenvolver uma resposta imunológica ao MAb que irá removê-lo completamente ou, pelo menos, reduzir a sua eficácia.

Uma alternativa para resolver este problema e para obter um anticorpo com o mínimo possível de resíduos murinos foi a construção de biblioteca de porções variáveis (VH e VL) a partir da biblioteca de Fabs humanos já disponível (Dantas-Barbosa et al., 2005), e a montagem da primeira biblioteca de scFv fixando o $\mathrm{VH}$ do anticorpo murino anti-CD20 (sintetizado a partir da sequência do rituximabe disponível em bancos de dados) e a biblioteca de VLs humanos (VL shuffling). Após a seleção das sequências de VL humanos com alta afinidade ao antígeno CD20 (pelo método de apresentação em fagos (phage display) foi desenhado e sintetizado quimicamente um scFv híbrido contendo a cadeia $\mathrm{VH}$ murina (do rituximabe) e uma cadeia VL humana (selecionada pelo VL shuffling). 


\subsection{Clonagem da porção $s c F v$ no vetor pCOMIRES $\Delta 600$}

A versão $\mathrm{scFv}$ foi sintetizadas quimicamente no vetor pBSK inserindo sítios para clivagem correspondentes às endonucleases Xma I e Xho I, para possibilitar a liberação do $\mathrm{scFv}$ e a clonagem no vector de expressão. Foi estabelecido como vetor de expressão o plasmídeo pCOMIRES $\Delta 600$ (Quilici et al., 2013)bcom uma versão scFv anti-CD3 humanizada(Quilici et al., 2013) desenvolvido no grupo de Imunologia Molecular qual tem a sequência gênica para os domínios $\mathrm{CH} 2$ e $\mathrm{CH} 3$ do fragmento cristalizável de imunoglobulina humana IgG presentes entre o sítio da enzima Xho I e da enzima EcoR I, de forma que a proteína liberada pela célula de mamífero, correspondesse ao fragmento $\mathrm{FvFc}$ do anticorpo quando fosse inserido o inserto $\mathrm{ScFv}$.

Este vetor de expressão possui como característica especial uma deleção de 600 pb no promotor de citomegalovírus que melhora a produção das proteínas recombinantes em células de mamíferos. (Quilici, 2013).Apresenta também um peptídeo sinal e um sítio de entrada ribosomal interno (IRES), separando o gene de $\mathrm{FvFc}$ e o gene Neo, que codifica a enzima aminoglucosidase 3 fosfotransfersa que conferirá as células transfectadas CHO-K1 e HEK-293, resistência ao antibiótico geneticina, um sinal de poliadenilação que é uma sequência que permitirá a adição de uma série de resíduos de adenina na região 3` do RNA mensageiro (mRNA) da proteína, fazendo com que ela fique estável nas células hospedeiras, como também e um sinal de terminação da transcrição, o gene Bla de resistência a ampicilina para a clonagem bacteriana em Escherichia coli, linhagem XL1BLUE, o qual possui o gene de resistência à tetraciclina. Desta forma foi desenvolvida a estratégia de clonagem e montagem da sequências codificadora do anticorpo recombinante hibrido, para a sua futura junção com a seqüência gênica da região Fc do veto de expressão e possibilitar a produção heteróloga da proteína recombinante na forma de anticorpo FvFc. (Figura12) 

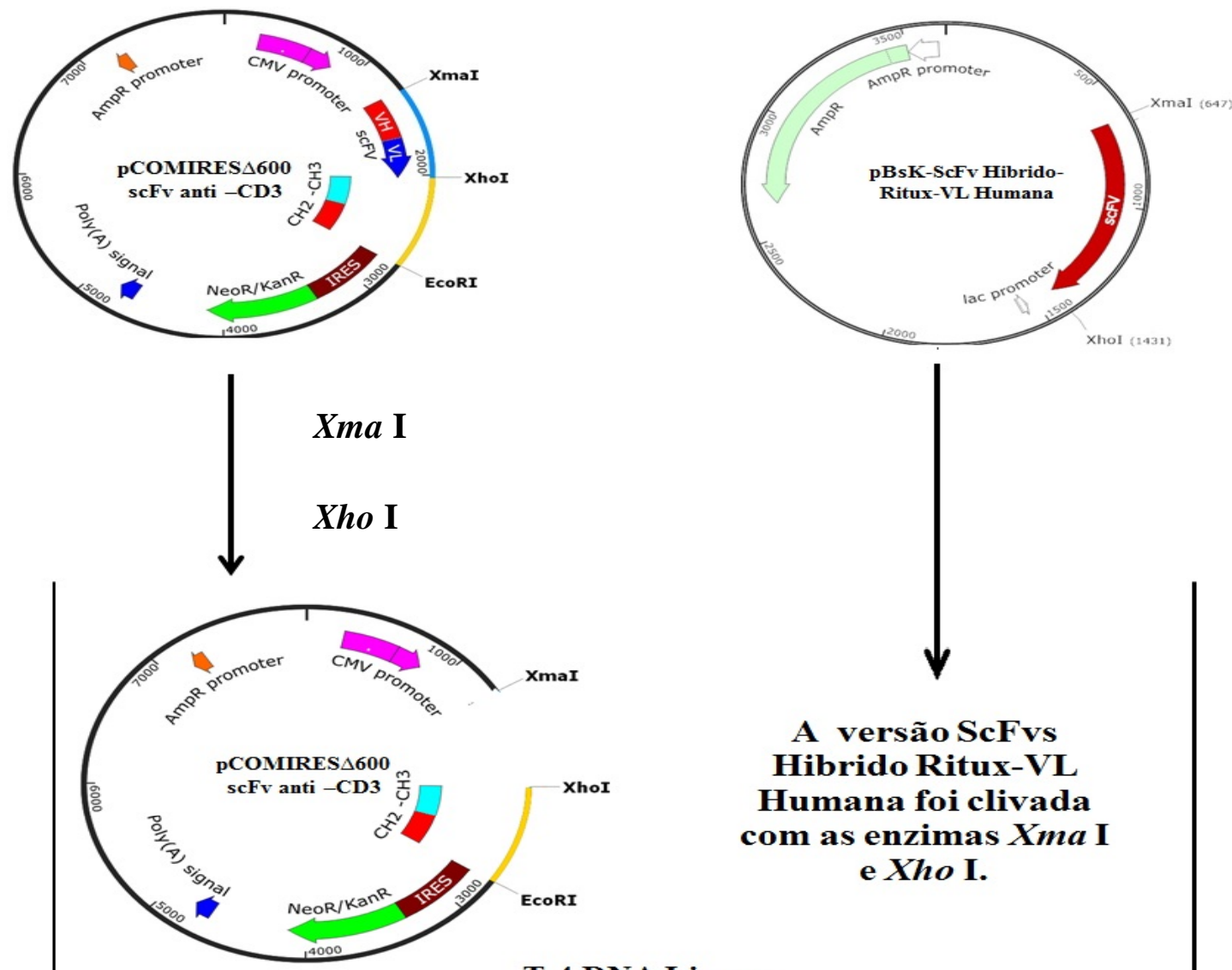

T 4 DNA Ligase
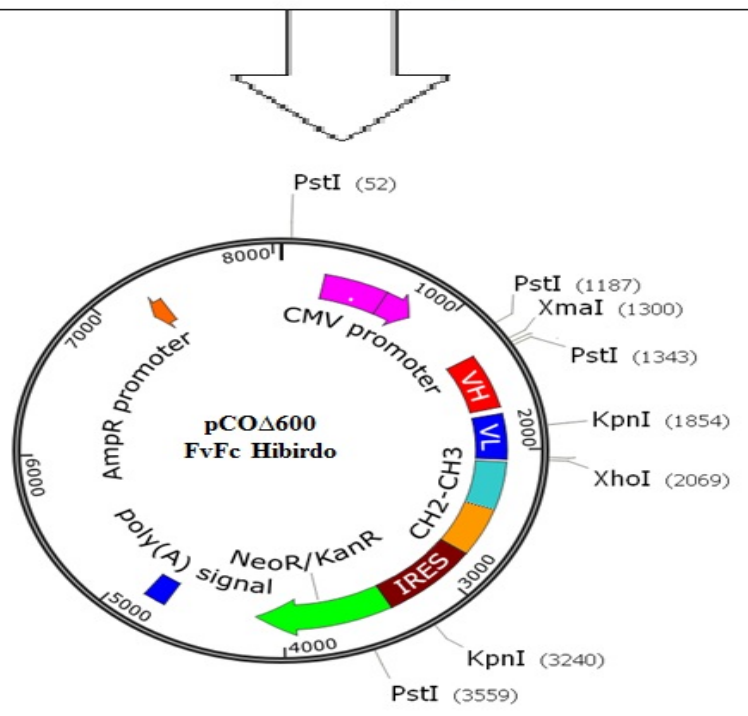

Figura 11: Estratégia para construção do vetor pCO $\mathbf{6 0 0 0} \mathrm{FvFc}$ hibrido. Para a clonagem da porção ScFv no vetor pCO $\Delta 600$ este e o vetor scFVHibrido_Ritux_VL Humana foram digeridos com as endonuclease Xho I e Xma I para liberação do vetor e do fragmento gênico respectivamente. Esses por sua vez foram ligados utilizando-se a enzima T4 DNA ligasse dando origem a construção vetor pCO $\Delta 600 \mathrm{FvFc}$ hibrido. Siglas; pCMV/IA: promotor de citomegalovírus contendo o íntron A; SV40 poli A: sinal de poliadenilicacao. 
Assim os dois plasmídeos originais foram amplificados utilizando células E. coli, linhagem XL1BLUE a qual possui o gene de resistência à tetraciclina. As extrações e purificações de DNA plasmideal foram desenvolvidas com os protocolos experimentais descritos em materiais e métodos, e as extrações em grande escala foram realizadas com Kit Quiagen. Após as extrações, os plasmídeos foram digeridos com as endonucleases Xma I e Xho I, que promoveu a liberação dos fragmentos correspondentes, onde no vetor pCOMIRES $\triangle 600$ permaneceria somente os fragmentos com as cadeias pesadas humanas e o linker, e no pBsK era liberado o fragmento scFv e a geração dos sítios para clonagem no vetor pCOMIRES $\Delta 600$, Os fragmentos obtidos após neste ensaio de restrição foram separados em gel de agarose 0,7\% (p/v) (Figura 12) os fragmentos foram eletroeluídos em gel de agarose preparados com tampão TAE. Posteriormente os fragmentos scFvs foram ligados ao vetor pCOMIRES $\Delta 600$ com T4 DNA ligasse da Invitrogen dando origem a construção pCO $\Delta 600$ FvFc Hibrido (H) (Figura 13)

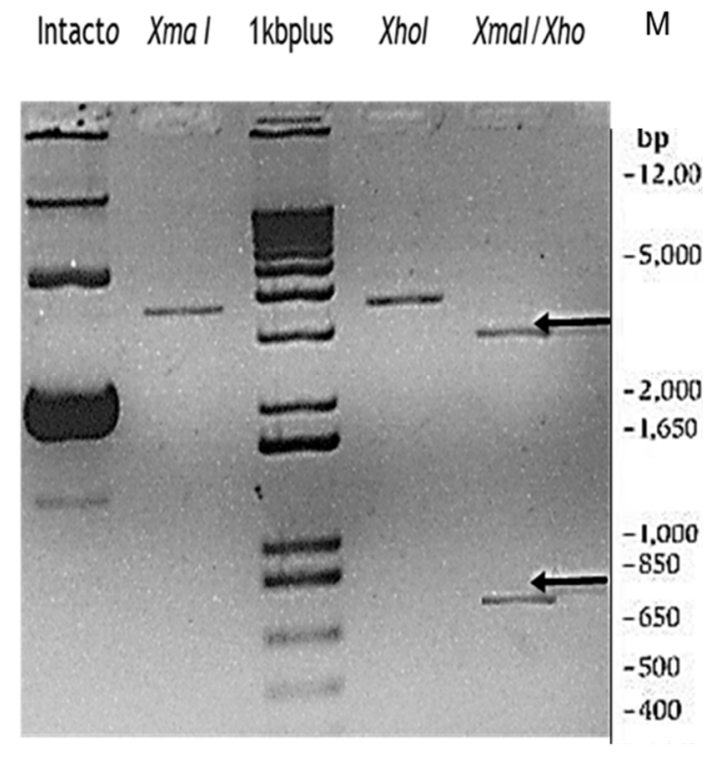

A)

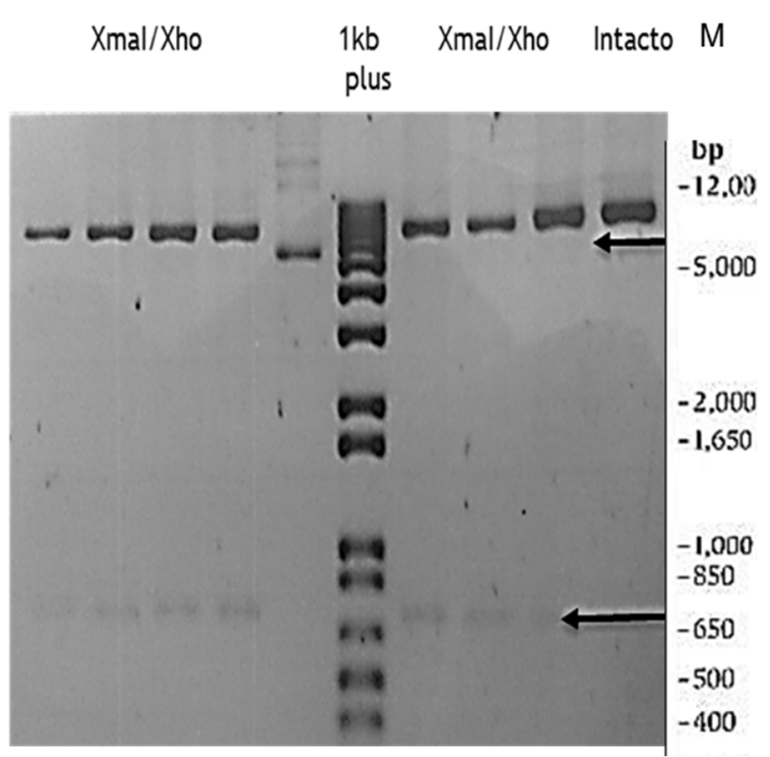

B)

Figura 12:Analises Perfil de restrição dos Plasmídeos; pBSK-ScFvHibridoRitux-VLHumana,e pCO $\Delta 600$ A) Perfil de restrição do plasmídeo pBSK-scFVHibrido-Ritux -VLHumana indicando os fragmentos liberados com a endonuclease Xma I Xho I em digestão dupla com liberação de fragmentos de entorno 2852 e 784pb; B) Perfil de restrição do plasmídeo do pCOMIRES $\Delta 600$ em digestão dupla com liberação de fragmentos de entorno 7271 e 720pb. Setas pretas destacando as bandas dos fragmentos liberados, Gel de agarose 0,8\%, DNA ladder $1 \mathrm{~Kb}$ plus. 


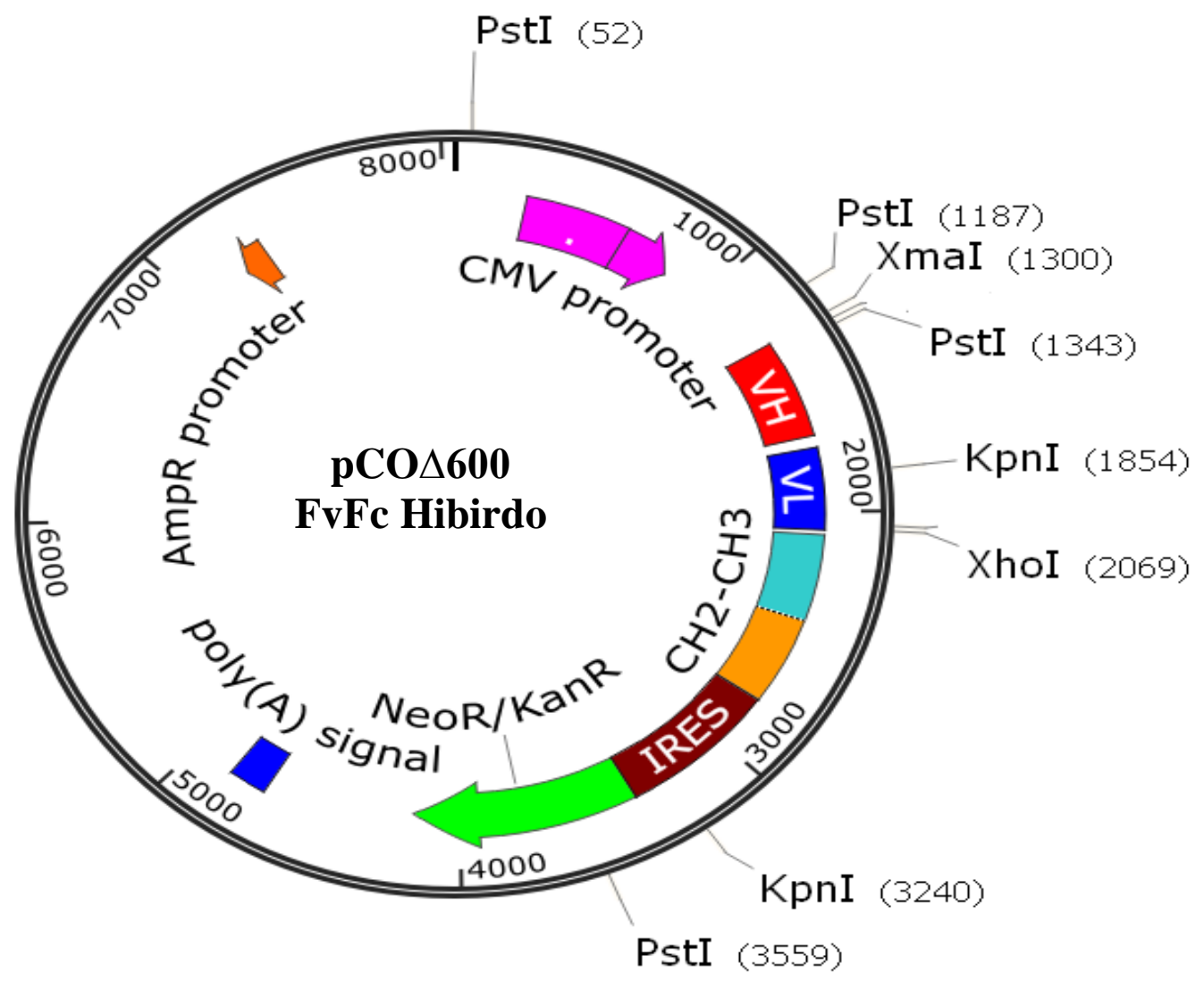

Figura 13: Desenho esquemático da versão do vector pCO $\Delta 600$ FvFc Hibrido (H), mostrando seus componentes e sítios de restrição das principais enzimas.

Células E. coli, linhagem XL1-Blue foram transformadas por eletroporação. Os clones transformantes foram escolhidos para preparação de DNA plasmideal em pequena escala para ser analisados em quanto a seu perfil de restrição. A partir de analises da sequência do ScFv, foram escolhidas para este fim as endonuclease Kpn I e Pst I esperandose a liberação de fragmentos de aproximadamente 6632 pb e 1370 pb com a endonuclease Kpn I e de 4535, 2200 ,1135 para a endonuclese Pst I; O perfil originado estava de acordo com o esperado, (Figura 14) dando indicio que a clonagem foi bem sucedida originando o vetor pCO $\Delta 600 \mathrm{FvFc}$ Hibrido $(\mathrm{H})$. 


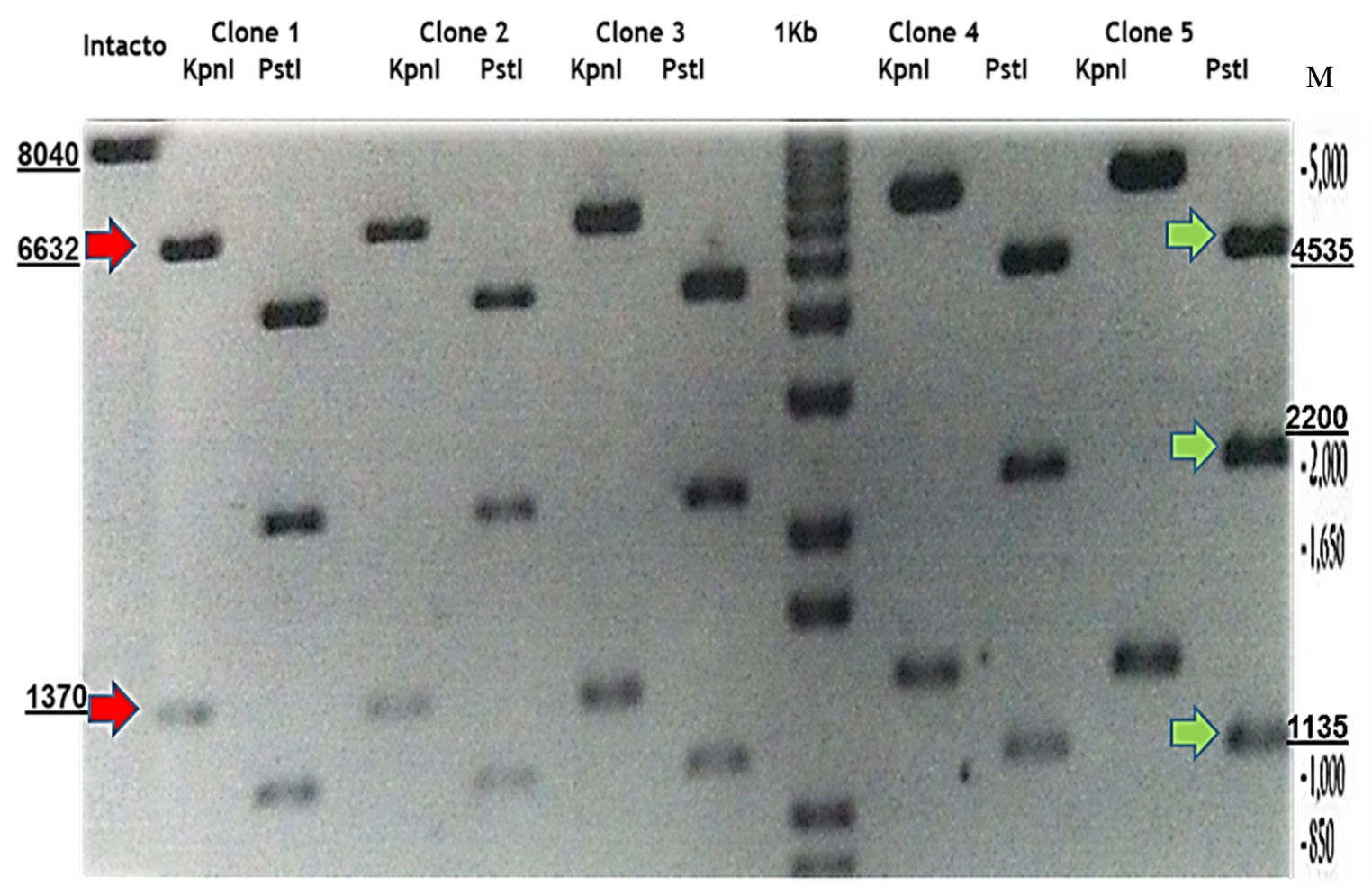

Figura 14: Confirmação da c a construção pCOL600 FvFc Hibrido (H). Perfil de restrição com as endonuclease Kpn I e Pst I do intacto / pCOMIRES $\Delta 600$ ) $\varepsilon$ clones 1-4. Setas vermelhas indicando os fragmentos liberados com a digestão com a endonuclease Kpn I de aproximadamente 6632 pbe1370 pb. Setas verdes indicando os fragmentos liberados com a digestão com a endonuclease Pst I de 4535,2200 e 1135 respectivamente M: $1 \mathrm{~kb}$ Plus ladder Invitrogen ${ }^{\circledR}$.

Após as análises do perfil de restrição dos clones recombinantes em comparação ao pCOMIRES $\triangle 600 \mathrm{com}$ scFv anti- CD3 os clones foram analisados por PCR utilizando oligonucleotídeos específicos para VH e VL da versão scFv. O primeiro par de iniciadores $X m a$ I e Xba I amplifica os domínios VH, enquanto que o segundo par de iniciadores $B g l$ II e Xho I amplifica os domínios VL. (Figura 15). Pela observação das bandas, podemos constatar que o vetor pCOMIRES $\triangle 600$ contém o inserto de nosso interesse (Figura 16). 


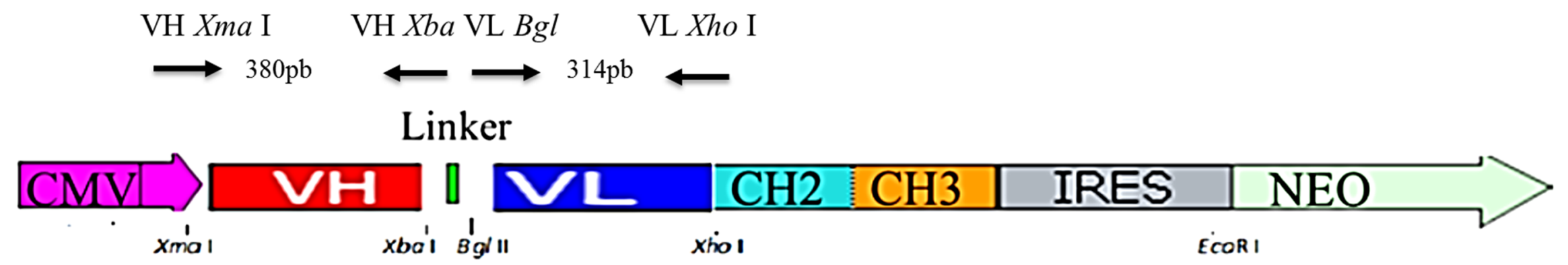

Figura 15: Desenho esquemático dos primers utilizados para confirmação das clonagens por PCR. 


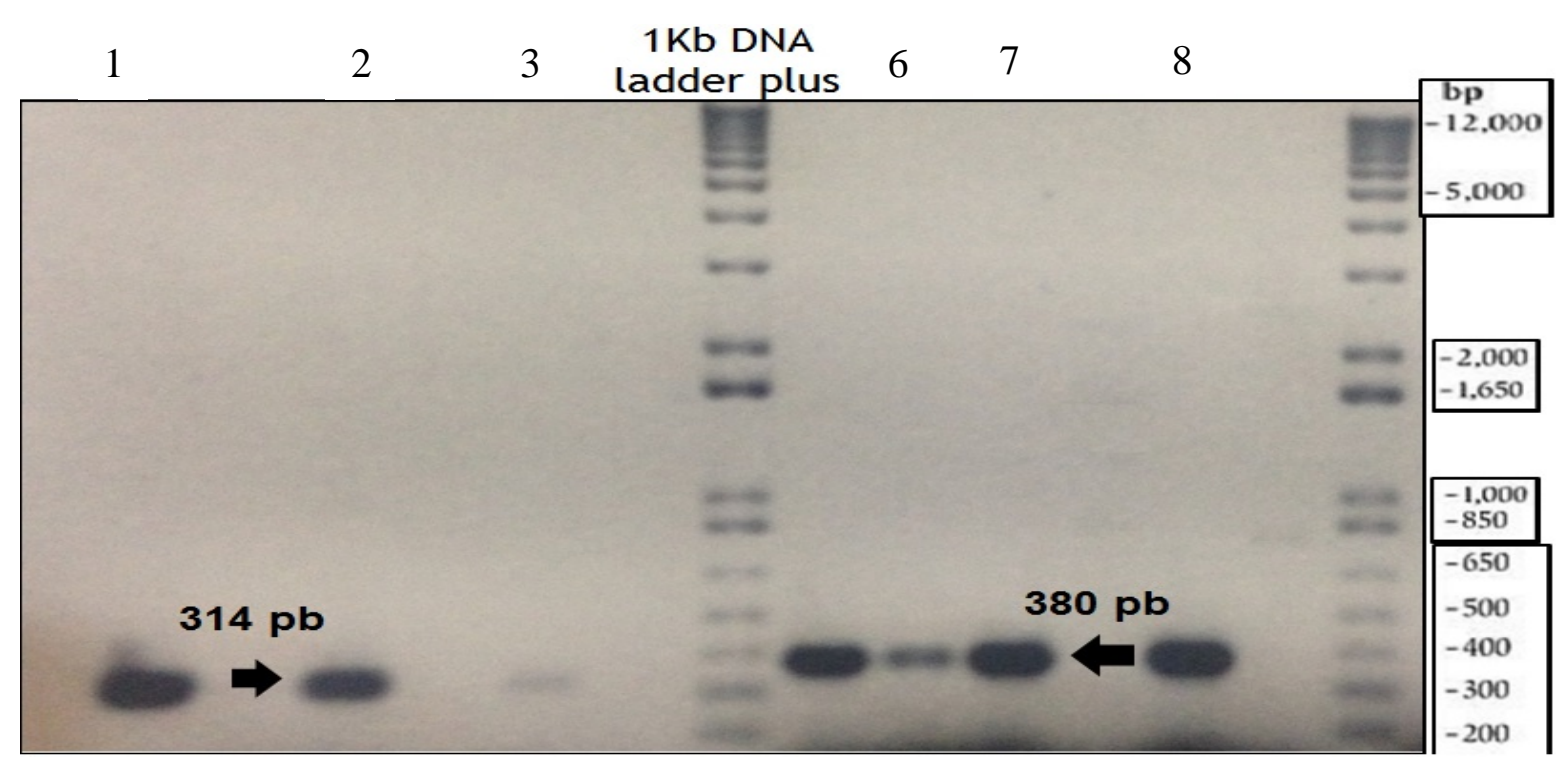

Figura 16: Análises em Gel de agarose $1 \%$ com o resultado da PCR da construção pCO $\triangle 600$ FvFc Hibrido: nos poços $\mathrm{n}^{\circ} 1,2$ e 3 a VL com 314 pb; no poço 4 o marcador $1 \mathrm{~kb}$ DNA ladder Plus de invitrogen; nos poços 5-8 a VH com $380 \mathrm{pb}$

\subsection{Transfecção em células de ovário de Hamster Chinês (CHO) e de Rim Embrionário Humano (HEK 293).}

As células do Ovário de Hamster Chinês (CHO) têm sido as células mais comumente utilizadas para a produção de proteínas heterólogas terapêuticas. Apesar da disponibilidade de uma ampla variedade de linhas celulares, as células CHO tornaram-se células padrão utilizadas na produção de proteínas recombinantes. Hoje quase $70 \%$ de todas as proteínas terapêuticas recombinantes são produzidas com elas. As células obtidas a partir do rim de embrião humano (HEK-293) também são uma ótima alternativa para a produção de glicoproteínas. Estas linhagens celulares são bem caracterizadas e permitem a transfecção, a amplificação e a seleção de clones produtores de proteína recombinante estáveis e moléculas complexas como os anticorpos.

Para as proteínas terapêuticas serem eficazes, elas devem ser sintetizadas em formas biologicamente ativas, exigindo o plegamento correto e as modificações pós-traducionais. Tais como glicosilação, que é um tipo de modificação onde certas porções de hidrato de carbono são adicionadas a resíduos específicos de aminoácidos da proteína, característica 
importante para a estabilidade da proteína recombinante e também para sua ligação ao antígeno.

Foi assim que as construções: pCO $\Delta 600 \mathrm{FvFc}$ Hibrido $(\mathrm{H})$; pCOMIRES $\Delta 600$ com a versão murino scFv $\mathrm{O},(\mathrm{O})$; pCOMIRES $\Delta 600$ com a versão humanizada scFv L (L) e pCOMIRES $\triangle 600$ com a versão humanizada scFv A (A) foram transfectadas para a análise dos níveis de expressão transiente e estável (em população mista), em células de ovário de hamster chinês versão K1 (CHO- K1) e células de rim de embrião humano (HEK-293). Além disso, foi realizada transfecção com o vetor pCOMIRES $\triangle 600$ utilizado no experimento como controle negativo e o vetor de pGFP/NEO (Invitrogen®) como controle positivo da transfecção, este vetor possui o gene repórter ou gene marcador (GFP, do inglês, Green Fluorescent Protein) que tem sido muito utilizado para a detecção de células transfectadas vivas, este gene foi clonado a partir da água-viva Aequeorea Vitoria. O GFP quando exposto à luz ultravioleta emite luz verde brilhante que pode ser vista por meio de um microscópio de fluorescência. Portanto, pode-se monitorar a expressão de GFP após transfecção sem a obtenção de extratos de células. As transfecções foram feitas em triplicata, a avaliação da eficiência da transfecção foi calculada por contagem do número de células fluorescentes em comparação com células totais num quadrante numa placa de cultura após 24 horas do ensaio de transfecção. O resultado é apresentado em percentagem (Figura 17), onde pode-se observar que as células CHO-K1 apresentam uma eficiência 2 vezes menor em comparação as células HEK-293 com umas percentagens de 30\% e $70 \%$ por cento respectivamente. 


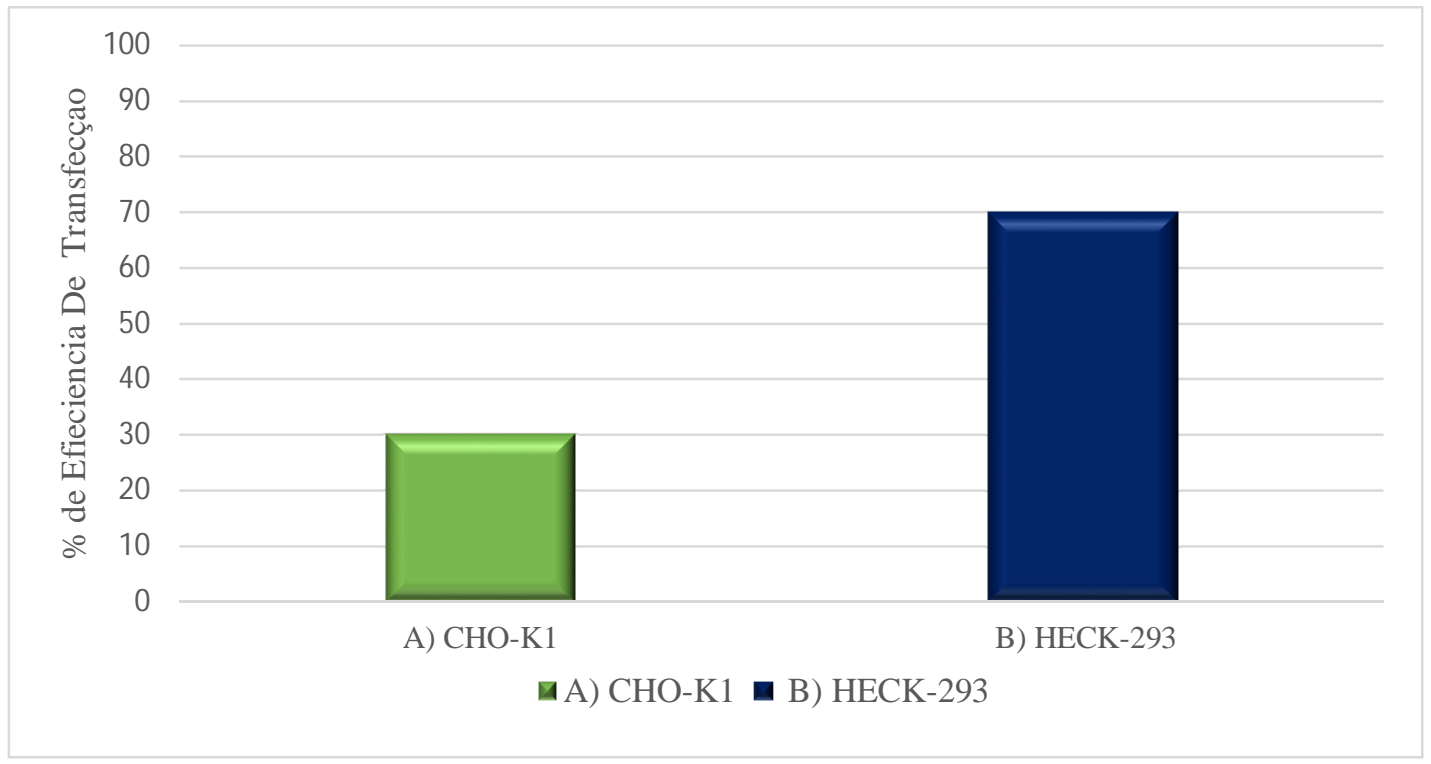

Figura 17: Eficiência de transfecção das células de mamífero. De acordo com a fluorescência emitida pelo gene pGFP. (A) CHO-K1. (B) HEK-293.

\subsection{Produção dos FvFes recombinantes.}

Após 72 horas da transfecção o meio foi substituído e adicionou-se $600 \mathrm{ug} / \mathrm{ml} \mathrm{de}$ geneticina, $\mathrm{O}$ meio contendo geneticina foi trocado a cada 48 horas. Para verificar a presença de proteínas recombinantes, Os meios que contêm o antibiótico foram adicionados aos poços controles que contém as células não transfectadas. Estas células foram usadas como controle de morte celular de células não transfectadas. A cada troca de meio as células foram observadas em microscópio óptico onde foram observadas sua morfologia e aderência a placa. Como as células não transfectadas são sensíveis a geneticina, aproximadamente três semanas após a transfecção essa células apresentavam fenótipo de células esféricas e perderem a aderência à placa de cultura demonstrando sua morte. A partir deste ponto assumia-se que as células transfectadas viáveis estavam selecionadas. Após este período as células dos poços transfectadas foram transferidas para garrafas de $75 \mathrm{~cm}^{2}$ e posteriormente para garrafas de $150 \mathrm{~cm}^{2}$ para aumentar a produção das proteínas recombinantes Os sobrenadantes destas culturas foram coletados uma vez por semana e armazenados para serem concentrados e purificados. 
Os sobrenadantes de cultura foram coletados para subsequente verificação por ELISA da presença e quantificação dos anticorpos recombinantes em população mista; Os anticorpos foram quantificados a partir de comparações com uma curva padrão realizada com IgG humana em concentrações conhecidas obtidas por meio de diluições seriadas. Os resultados revelaram a presença dos anticorpos recombinantes no meio de cultivo, e obtendo-se uma maior eficácia na produção dos anticorpos recombinantes quando se utilizou como sistema de expressão a linhagem celular HEK -293 com produções para cada versão de 72,56 ng/mL para a versão $\mathrm{H}, 112,24 \mathrm{ng} / \mathrm{mL}$ para versão $\mathrm{O}, 109,76 \mathrm{ng} / \mathrm{mL}$ para versão $\mathrm{L}$, e 45,98 ng/mLpara versão A. Estes primeiros resultados são cerca de 5 vezes maior que na produção de as proteínas recombinantes em células CHO-K1 com quantidades de 6,936 ng/mL para a versão H, 40,663ng/mL para versão O, 27,956 ng/mL para versão L, 9,693 ng/mL para versão A (Figura 18). 

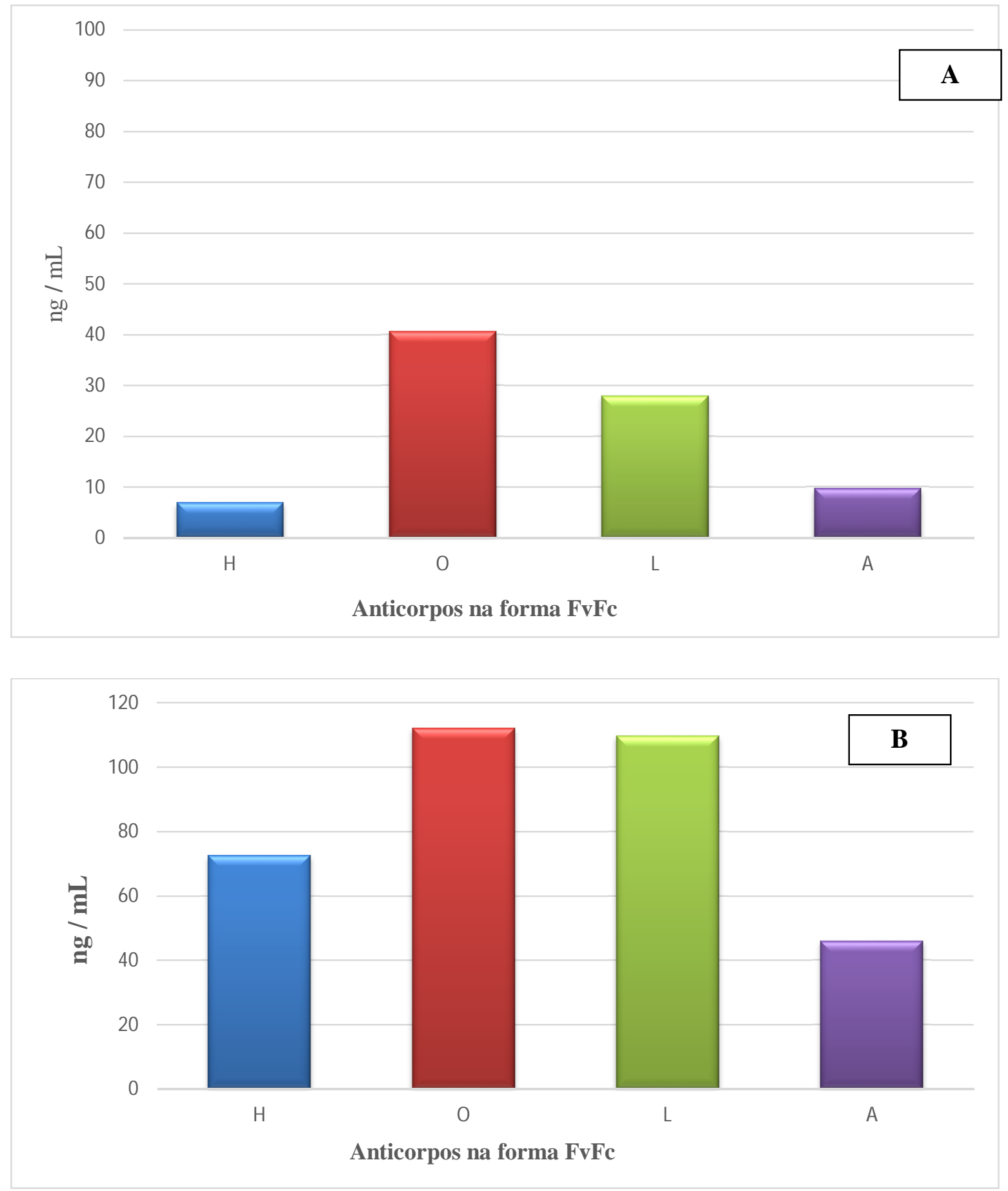

Figura 18: Níveis de produção dos anticorpos nos sobrenadante de cultura.Células CHO-K1 (A) HEK-293 (B). H:pCO $\Delta 600 \mathrm{FvFc}$ Humanizado. (O): Vetor pCOMIRES $\Delta 600$ com a versão Murino scFv O (L): Vetor pCOMIRES $\triangle 600$ com a versão humanizada scFv L. (A) Vetor pCOMIRES $\Delta 600$ com a versão humanizada $\mathrm{scFv}$ A. 
Os dados aqui apresentados em relação a transfecção e produção das proteínas são similares aos observados em dados da literatura para expressão de células aderidas utilizando vetores com o promotor CMV e a utilização de linhagens celulares CHO-K1e HECK-293 para produção de proteínas recombinantes (Li et al., 2007; Suen et al., 2010) achando um rendimento de até 12 vezes maior na células HEK-293 em comparação as células CHO-K1 A expressão transiente em células HEK tem atraído um interesse considerável devido à sua capacidade de fornecer quantidades de proteínas num período de tempo razoável.(Bollin et al., 2011) já para expressão transitória em CHO tem -se menores níveis de expressão em comparação com células HEK transfectadas transientemente (Croset et al., 2012)

A produtividade de transfecção transiente depende de múltiplos fatores, incluindo a proporção da população de células transfectadas, a capacidade das células para crescer ao longo do tempo em um dado meio, a eficiência de transcrição e tradução nas células hospedeiras e o processamento de proteínas recombinante; Estudos também demostram que o número de células transfectadas não é significativamente influenciado pela quantidade de DNA de plasmídeo, propondo para isso que a expressão do gene bem sucedida é ditada, em vez da modulação de células transfectadas para um estado competente de expressão (Bollin et al., 2011). E de grande importância cuidar do acúmulo de amônia e lactato durante a cultura de células sendo este capaz de afetar negativamente o crescimento celular e a qualidade da proteína. Estes dois metabolitos secundários são gerados a partir de fontes de energia, tais como glutamina e glicose (Kim et al., 2012).

É de especial cuidado, vigiar as condições específicas para a produção de glicoproteínas recombinantes de forma fidedigna em relação aos processos pós traducionais, e principalmente em relação a glicosilação, vigiando a quantidade de nutrientes, pH, e temperatura. As concentrações de oxigênio dissolvido ou de amônia podem ter um impacto significativo sobre a distribuição das estruturas de glicano. Além das condições ambientais e nutricionais da cultura de células $\mathrm{CHO}$, a taxa específica de crescimento celular também pode afetar as estruturas de glicano. Estudos mostram claramente que as proteínas expressas nestas duas linhas celulares de mamífero frequentemente utilizadas têm diferenças significativas no seu padrão de glicosilação (Croset et al., 2012). O tamanho e número das estruturas de glicano varia, bem como a quantidade de ácido siálico, resultando em diferentes padrões de 
isoformas, fazendo que a população de proteínas seja mais ou menos ácida. O que estas diferenças têm sobre a atividade, as interações da proteína, a estabilidade, a biodistribuição e a meia-vida in vivo ainda não foi determinada (Suen et al., 2010).

Embora, a obtenção de clones estáveis seja a mais adequada para atingir altos níveis de produção, ela requer maior tempo e custos mais elevados associados com a geração de uma linha de células de mamíferos estavelmente transfectadas de alta produção; por custos de produção decidiu- se trabalhar com a população mista de células CHO- K1 e HEK-293 produtoras dos FvFcs recombinantes, segundo (Silva et al., 2009b),esta estratégia é possível embora não seja a mais eficaz. Diante desses resultados, optou-se por manter a cultura de células nessas condições com o intuito de gerar um acúmulo de sobrenadante suficiente para preparação das proteínas para as próximas etapas do trabalho.

\subsection{Purificação}

As proteínas recombinantes produzidas a partir da cultura de transfectomas estáveis obtidos como descrito acima, foram concentrados e purificados por cromatografia de afinidade, através da coluna ImmunoPure Plus Immobilized Protein A (Pierce®). Essa coluna apresenta a proteína A conjugada a sefarose. A proteína A tem a capacidade de se ligar a um grande número de moléculas de superfície celular, além das imunoglobulinas, tais como receptores de Fc do tipo II (FcR-II), moléculas de adesão, receptor do fator de crescimento do endotélio vascular, receptor de célula T (TCR), antígenos HLA-AB entre outros. Pertencentes a superfamília gênica das Imunoglobulinas e possuem domínios "Ig-like" (regiões homólogas aos domínios constantes ou variáveis das imunoglobulinas), que possuem afinidade pela proteína A (Vanamala et al., 2003). Logo, pode ser utilizada na purificação de fragmentos de anticorpos que contenham os domínios $\mathrm{CH} 2-\mathrm{CH} 3$ de Imunoglobulinas, como os FvFc.

Após a purificação, os sobrenadantes foram concentrados utilizando a membrana de celulose Centricon da Millipore. YM-30 (Millipore), com exclusão de 30 kDa, e dialisadas para se trocar o tampão para PBS. As frações coletadas da coluna foram analisadas quanto à presença das proteínas recombinantes por ensaio de Dot Blot (Figura 19). O resultado apresentado 
indica que a purificação foi bem sucedida e que as proteínas foram concentradas em uma única fração.

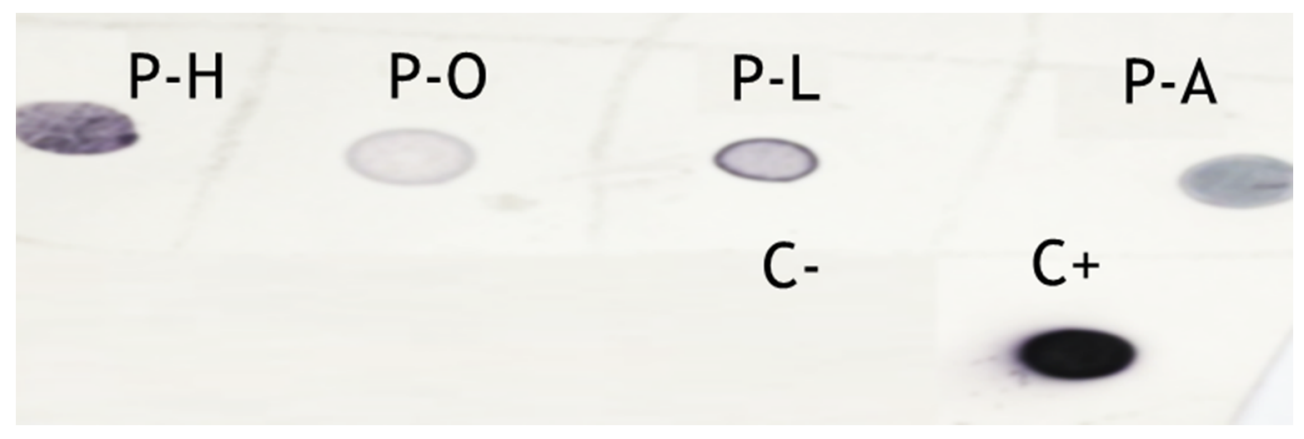

Figura 19: Imunodetecção dos FvFes após purificação e concentração. Dois microlitros de cada fração coletada foram aplicados em membrana de nitrocelulose e a presença dos FvFcs recombinantes foi detectada com anti-Fc humana conjugado a fosfatasse alcalina. P-H; purificação da versão H. P-O: purificação da versão O. P-L: purificação da versão L. P-A: purificação da versão A. C+: Controle positivo com $1 \mu \mathrm{g}$ de IgG humana. C-: Controle negativo.

A quantificação dos FvFes foi feita a partir da obtenção de uma curva padrão com concentrações conhecidas de IgG humana (Figura 20). Com base na equação da reta obtida pela curva padrão calculou-se que a concentração dos FvFcs foram de: 752 ng para versão H 2,063 ng para versão O, e 513 ng para versão L e 175ng para a versão A.

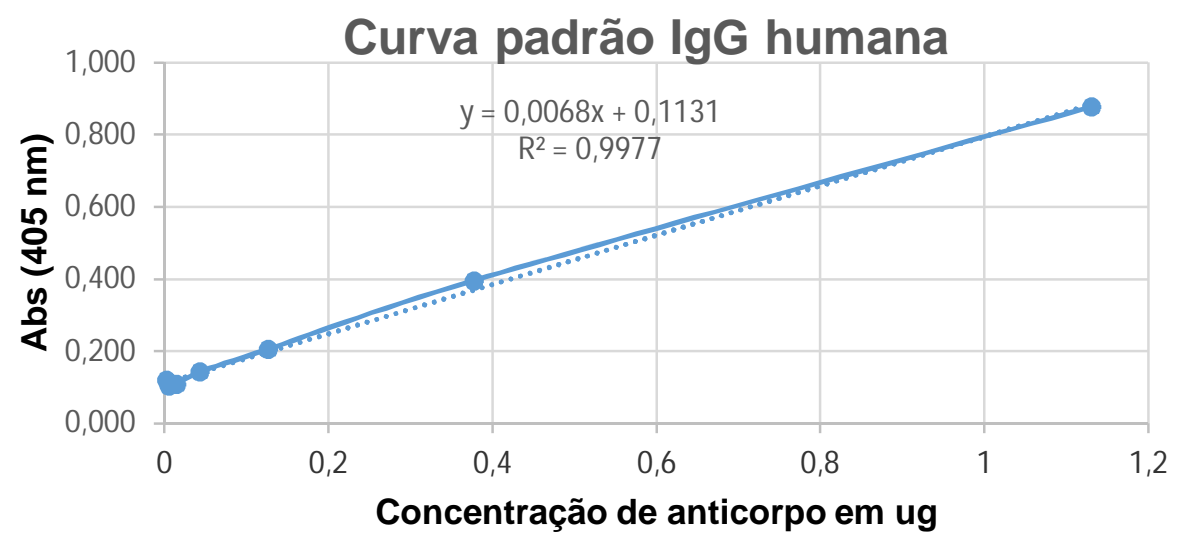

Figura 20: Curva-padrão para quantificação por ELISA. O gráfico apresenta a linha tendência da quantificação do padrão de $\operatorname{IgG}$ humana utilizado. A partir desse gráfico foi obtida a equação da reta, que foi usada para estimar a concentração dos FvFc purificados. 
Os resultados obtidos não correspondem ao demostrado na literatura para expressão de proteínas recombinantes em células aderidas utilizando-se vetores com o promotor CMV (Kim et al., 2012; Mus-Veteau, 2010), podendo ser devido ao acúmulo de amônia e lactato, que é um produto do lixo tóxico gerado pelo metabolismo celular (glicoses) e fonte de energia (tais com a glutamina). Propondo-se assim que as condições dos meios de cultura são de grande importância para manutenção das células de mamífero e um fator importante que pode afetar uma ótima produção de proteínas recombinantes, somando ao fato que no processo de purificação por cromatografia de afinidade com a coluna ImmunoPure Plus Immobilized Protein A (Pierce®) na bancada não se obteve uma taxa de recuperação esperada para o volume de sobrenadante de cultura purificada, sendo essa de apenas $1 \%$, após verificação das condições requeridas e do $\mathrm{Ph}$ dos tampões s utilizados. Essa porcentagem de recuperação foi aumentada para $20 \%$ com a utilização do equipamento AKTA purifier (GE Healthcare). Mesmo com esse ganho, considera-se uma taxa baixa de recuperação.

Sabe-se que a proteína A é um excelente ligante na cromatografia de afinidade, a desnaturação das IgG por contato com a proteína A é conceitualmente paralelo ao fenómeno de ajuste induzido nos sistemas de enzima-substrato. A IgG é desnaturada para entrar em consenso com a topografia química da proteína A(Deisenhofer, 1981) ), a que é um ligante de proteína eletronegativo geralmente hidrofóbico e confere sua elevada especificidade e afinidade para $\operatorname{IgG}($ Langone, 1982). Outra característica cromatográfica importante é a capacidade de desnaturação ao primeiro contato, o que aumenta a sensibilidade de $\mathrm{C} \gamma 2$ ao composto desnaturação (tampão) após a exposição a um pH de 3,5, portanto eliminando a necessidade de condições mais extremas de eluição impostas por outros ligantes de afinidade biológica, tais como a proteína L, a proteína $\mathrm{G}$ e de imunoafinidade. Pesquisas mostram que o segundo domínio constante $(\mathrm{C} \gamma 2)$ de IgG colapsa completamente a $\mathrm{pH} 3$, isto faz com que as nossas condições de eluição de proteína por cromatografia de afinidade propostas preocupantes, dado que geralmente a faixa de $\mathrm{pH}$ é de 2-3 para proteína $\mathrm{G}$, e para anticorpos eluidos a partir de proteína A a eluição deve ser feita a um pH de 3,5 ou mais, e especialmente, a atual geração de proteínas recombinantes que se ligam à proteína $\mathrm{A}$ apenas pela região Fc(Gagnon, 1996). 
Foi demostrado em pesquisas recentes uma eluição mais eficiente quando a molécula de IgG encontra-se numa conformação mais reduzida apresentando uma configuração dobrada; A flexibilidade inerente da dobradiça é aumentada pela flexibilidade imposta pelo composto de desnaturação sob condições ácidas, o que permite que a região Fab entre em contato com o domínio C $\gamma 3$ (Latypov et al., 2012).

Assim também foi confirmado que o tamanho hidrodinâmico da IgG é aumentado de acordo com a concentração de $\mathrm{NaCl}$ até mesmo a pH baixo, diminuindo drasticamente a sua recuperação pós-purificação (Gagnon et al., 2015); Considerando que o nosso tampão de eluição contém grande quantidade de $\mathrm{NaCl}$, isso poderia ser outra causa pelo qual obtivemos uma baixa recuperação, isto pode-se resolver com a adição de arginina para melhorar a eluição da IgG da Proteína A, especificamente, porque ela relaxa interações hidrofóbicas (Arakawa et al., 2004) O seu resíduo guanida - um análogo de guanidina - também conhecido por ser um forte dador-aceptor de hidrogênio, permite à arginina uma melhor recuperação de que a obtida com $\mathrm{NaCl}$ as ligações de hidrogénio e interações hidrofóbicas, em parte, compensa o aumento no tamanho da $\mathrm{IgG}$, em contraste com $\mathrm{NaCl}$, que agrava os efeitos sobre o tamanho do IgG. Outra maneira de enfrentar e resolver esse problema é a implementação de protocolos automatizados que são eficientes em tempo e custo permitindo uma purificação de alto desempenho, usando protocolos de cromatografia de troca aniônica e etapas de cromatografia de troca iônica, troca de tampão, e cromatografia de interação hidrófoba para obter taxas de até $70 \%$ de rendimento global(Camper and Viola, 2009)

Após a quantificação, as mostras foram analisadas por meio de um sistema de microeletroforese usando nanocapilares (Bioanalyzer), para determinar o grau de pureza e confirmação da sua quantificação. As amostras foram eletroforeticamente separadas nos microcanais preenchidos com solução polimérica. A detecção foi baseada na fluorescência induzida a laser por um corante fluorescente que foi adicionado à solução polimérica e ligado, não covalentemente, às micelas proteína-SDS. O software Bioanalyzer calcula automaticamente o tamanho e a concentração de cada pico separado e expõe os resultados em tempo real. A quantidade de proteína recombinante nas amostras expressa como a porcentagem de proteína total pode ser determinada diretamente da tabela dos resultados fornecida pelo software. Os resultados obtidos por GelChip-CE foram comparados com 
aqueles obtidos por gel de eletroforese convencional (15\% SDSPAGE). Analisando o gel e os histogramas para cada uma das amostras podemos observar um alto grau de pureza das proteínas purificadas (Tabela 4), não sendo possível a detecção de contaminantes; Pode-se observar as bandas de $67 \mathrm{kDa}$ correspondente à os FvFcs (Figura 21).

\begin{tabular}{|c|c|c|}
\hline \multirow{2}{*}{ FVFC } & \multicolumn{2}{|c|}{ \% PUREZA } \\
\cline { 2 - 3 } & CHO & HEK \\
\hline H & 100 & 75 \\
\hline O & 80 & 53 \\
\hline L & 100 & 60 \\
\hline A & 66 & 50 \\
\hline
\end{tabular}

Tabela 4: Porcentagem de pureza de FvFc purificados

[kDa]
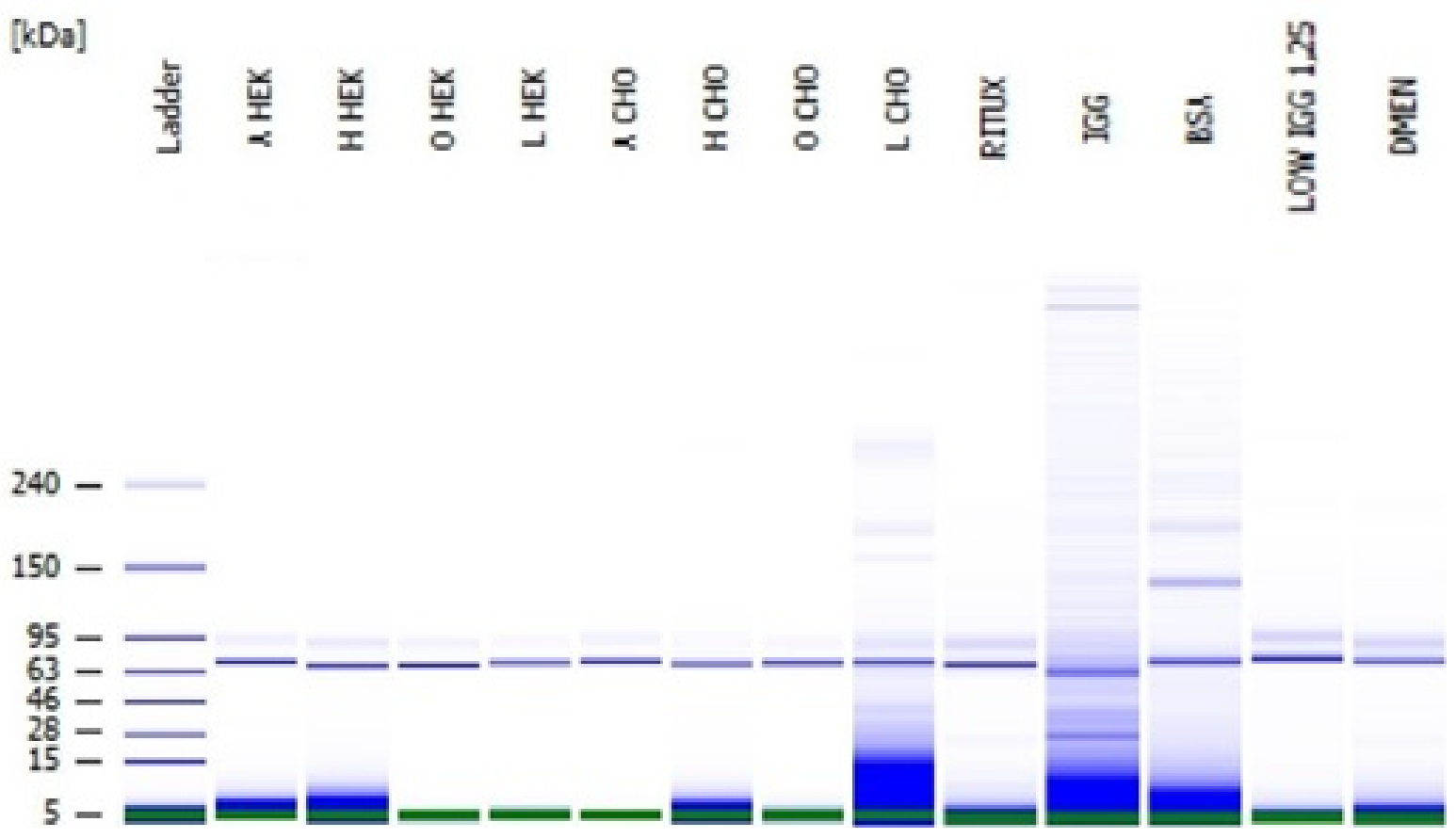

Figura 21: Análise da purificação dos FvFc por GelChip-CE. Bioanalyzer. Baseada na fluorescência induzida a laser de um corante fluorescente, no qual foi adicionado na matriz de separação. As amostras foram separadas individualmente em uma solução polimérica apropriada fornecida pelo kit Protein 200 Plus LabChip, como recomendado pelo fabricante. MM é o padrão de massa molecular. A molécula FvFc migra como um monómero de $67 \mathrm{kDa}$, podemos observar a formação desta bandas correspondentes aos $\mathrm{FvFc}$. 
Posteriormente, os FvFcs foram submetidos à eletroforese em gel desnaturante de poliacrilamida (SDS-PAGE) e analisadas por Wersten-Blot (Figura 22). Para a detecção dos FvFcs recombinantes utilizou-se um anticorpo anti-Fc humana conjugado à fosfatase alcalina e a revelação foi feita com NBT/BCIP. Observou-se uma banda de aproximadamente $67 \mathrm{kDa}$ que corresponde ao tamanho esperado para o FvFc após a redução e separação do dímero.

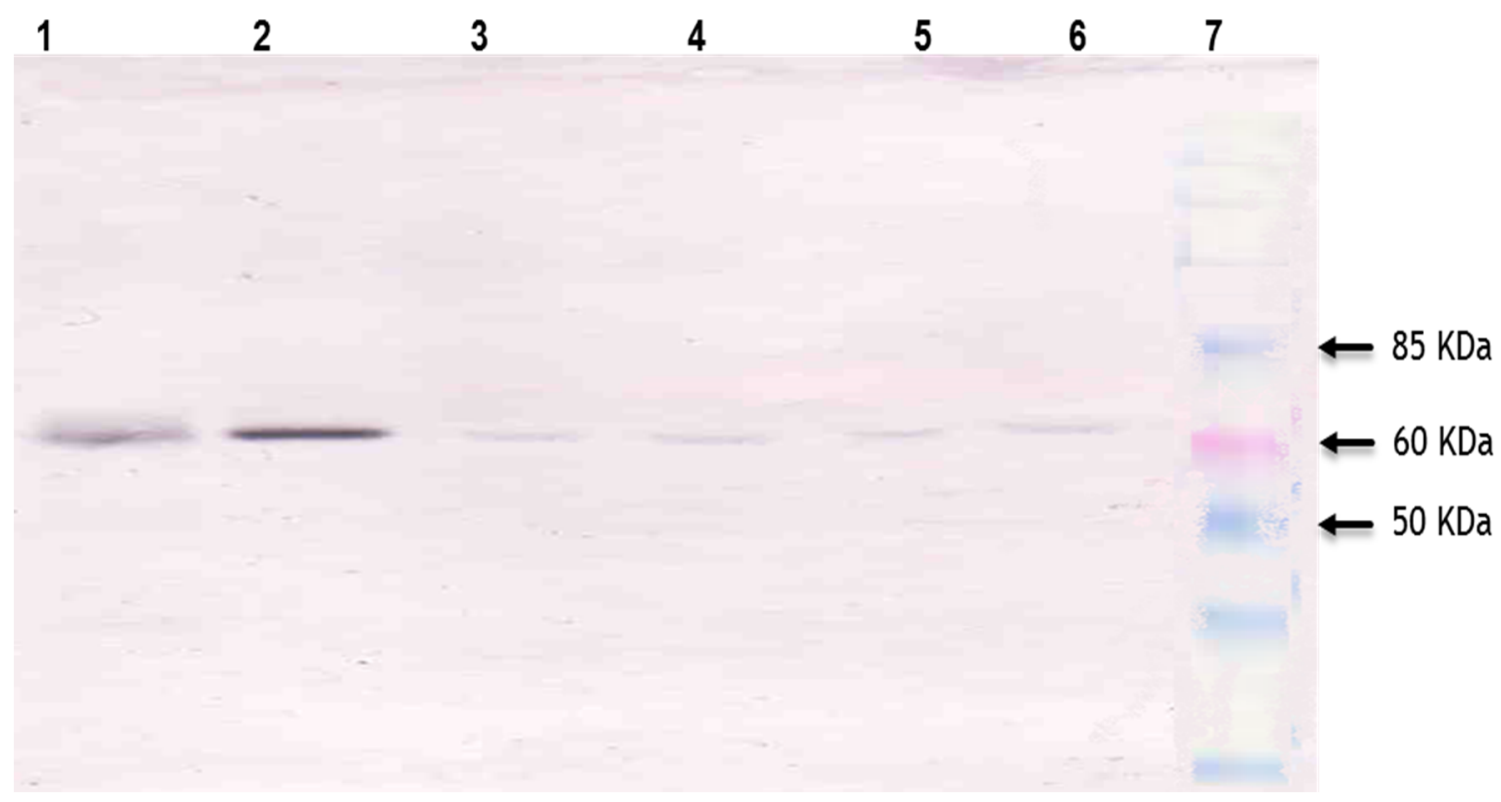

Figura 22. Análise dos FvFes produzidos por Western Blot: Foi realizada uma eletroforese em gel SDSPAGE $10 \%$ para separação das proteínas purificadas as quais eram posteriormente transferidas para uma membrana de nitrocelulose e revelada com IgG de coelho e anti-IgG de coelho conjugado a fosfatase alcalina. 1- IgG humana utilizada como controle positivo. 2 - Rituximabe. 3 - FvFc H, 4 - FvFc O, 5 - FvFc L, 6 - FvFc A. 7 - Marcador molecular Bench MarkerTM Prestained - Invitrogen ${ }^{\circledR}$. 


\section{CONCLUSÕES E PERSPECTIVAS}

Nesse trabalho, foi realizada a humanização e produção na forma FvFc de 04 (quatro) versões de anticorpo Anti-CD20 em células de mamíferos por meio da técnica CDR grafting e transfecção transiente, com o objetivo de obter anticorpos mais específicos e menos imunogênicos. Das versões trabalhadas, 03 (três) foram formadas a partir de arcabouços humanos escolhidos em banco de dados e as CDRs murinas do anticorpo monoclonal selecionadas da mesma maneira e 01 (uma) versão formada por arcabouços humanos e sequências de genes codificantes das regiões CDRs escolhidas em bancos de dados com alta similaridade às CDRs murinas do anticorpo monoclonal quimérico Rituximabe. O que conferirá aos anticorpos especificidade e êxito na depleção das células B sem ser imunogênico para seres humanos.

A clonagem dos genes de interesse em vetores pertinentes para a expressão em células de mamíferos é de extrema importância para obtenção da proteína recombinante. A escolha do vetor PCO 600 (Quilici et al., 2013) foi uma ótima opção, devido a sua deleção de 600 pares de bases no promotor CMV otimizando desta forma a produção de fragmentos na forma FvFc em células de mamíferos CHO-K1 e HEK 293.

Em relação à purificação houve uma alta perda da proteína recombinante, possivelmente, por causa da escolha incorreta das condições e buffers ideais para a purificação, podendo ser corrigido, melhorado o tamanho da $\operatorname{IgG}$ durante qualquer etapa da cromatografia de afinidade por modificações do $\mathrm{pH}$ no conteúdo dos buffers, em especial no buffer de eluição, e adição de aditivos como a arginina que debilitam os enlaces de hidrogênio e interações hidrofóbicas entre $\operatorname{IgG}$ e a proteína A, obtendo-se melhores resultados na quantidade de proteína recombinante recuperada. Outra alternativa de abordar este problema poderia ser a inclusão de múltiplos passos e diferentes métodos de cromatografia de forma automatizada, sendo uma possível maximização do rendimento global da quantidade dos anticorpos purificados. Embora a quantidade de proteína recombinante não tenha atingindo o resultado esperado, foi possível a produção, obtenção e purificação desses anticorpos no formato fragmentado FvFc anti-CD20, em população mista de células de mamíferos, podendo propor a obtenção de clones estáveis para alcance dessas proteínas em larga escala 
utilizando as 04 (quatro) construções com o plasmídeo pCO $\Delta 600$. A próxima etapa desse trabalho será determinar a capacidade de ligações e análises das atividades biológicas efetoras: ADCC, $\mathrm{CDC}$, destas moléculas. 


\section{BIBLIOGRAFIA}

Abbas, A.K., Lichtman, A.H., and Pillai, S. (2014). Cellular and Molecular Immunology: with STUDENT CONSULT Online Access (Elsevier Health Sciences).

AGUILLON GUTIERREZ, J.C. (2014). DESARROLLO Y ESTANDARIZACION DE TECNOLOGIAS PARA LA PRODUCCION DE ANTICUERPOS MONOCLONARES MODIFICADOS CON APLICACIONES EN BIOMEDICINA.

Alduaij, W., and Illidge, T.M. (2011). The future of anti-CD20 monoclonal antibodies: are we making progress? Blood 117, 2993-3001.

Arakawa, T., Philo, J.S., Tsumoto, K., Yumioka, R., and Ejima, D. (2004). Elution of antibodies from a Protein-A column by aqueous arginine solutions. Protein expression and purification $36,244-248$.

Bassing, C.H., Swat, W., and Alt, F.W. (2002). The mechanism and regulation of chromosomal V (D) J recombination. Cell 109, S45-S55.

Beerli, R.R., and Rader, C. (2010). Mining human antibody repertoires. In MAbs (Taylor \& Francis), pp. 365-378.

Beers, S.A., Chan, C.H., French, R.R., Cragg, M.S., and Glennie, M.J. (2010). CD20 as a target for therapeutic type I and II monoclonal antibodies. In Seminars in hematology (Elsevier), pp. 107-114.

Binder, M., Otto, F., Mertelsmann, R., Veelken, H., and Trepel, M. (2006). The epitope recognized by rituximabe. Blood 108, 1975-1978.

Bologna, L., Gotti, E., Da Roit, F., Intermesoli, T., Rambaldi, A., Introna, M., and Golay, J. (2013). Ofatumumab is more efficient than rituximabe in lysing B chronic lymphocytic leukemia cells in whole blood and in combination with chemotherapy. Journal of immunology 190, 231-239.

Bollin, F., Dechavanne, V., and Chevalet, L. (2011). Design of Experiment in CHO and HEK transient transfection condition optimization. Protein Expression and Purification 78, 61-68. Brodsky, R.A. (2009). How I treat paroxysmal nocturnal hemoglobinuria. Blood 113, 65226527.

Buss, N.A., Henderson, S.J., McFarlane, M., Shenton, J.M., and de Haan, L. (2012). Monoclonal antibody therapeutics: history and future. Current opinion in pharmacology 12 , 615-622. 
Caldas, C., Coelho, V.P., Rigden, D.J., Neschich, G., Moro, A.M., and Brígido, M.M. (2000). Design and synthesis of germline-based hemi-humanized single-chain Fv against the CD18 surface antigen. Protein Engineering 13, 353-360.

Camper, D.V., and Viola, R.E. (2009). Fully automated protein purification. Analytical biochemistry 393, 176-181.

Cohen, J., and Wilson, A.W. (2009). New challenges to medicare beneficiary access to mAbs. In MAbs (Taylor \& Francis), pp. 56-66.

CRAGG, M.S. (2011). CD20 antibodies: doing the time warp. Blood

Croset, A., Delafosse, L., Gaudry, J.-P., Arod, C., Glez, L., Losberger, C., Begue, D., Krstanovic, A., Robert, F., Vilbois, F., et al. (2012). Differences in the glycosylation of recombinant proteins expressed in HEK and CHO cells. Journal of Biotechnology 161, 336348.

da Silva, F.A., Corte-Real, S., and Goncalves, J. (2008). Recombinant antibodies as therapeutic agents. BioDrugs 22, 301-314.

Dall' Acqua, W.F., Damschroder, M.M., Zhang, J., Woods, R.M., Widjaja, L., Yu, J., and $\mathrm{Wu}, \mathrm{H}$. (2005). Antibody humanization by framework shuffling. Methods 36, 43-60.

de Lorenzo-Pinto, A., Rodríguez-González, C.G., and Ais-Larisgoitia, A. (2013). Nuevos tratamientos para la esclerosis múltiple. Medicina Clínica 140, 76-82.

Deisenhofer, J. (1981). Crystallographic refinement and atomic models of a human Fc fragment and its complex with fragment B of protein A from Staphylococcus aureus at 2.9and 2.8-.ANG. resolution. Biochemistry 20, 2361-2370.

Du, J., Wang, H., Zhong, C., Peng, B., Zhang, M., Li, B., Huo, S., Guo, Y., and Ding, J. (2007). Structural basis for recognition of CD20 by therapeutic antibody Rituximabe. The Journal of biological chemistry 282, 15073-15080.

Eisenberg, R., and Looney, R.J. (2005). The therapeutic potential of anti-CD20 "what do Bcells do?". Clinical immunology 117, 207-213.

España, A., Ornilla, E., and Panizo, C. (2013). Rituximabe en dermatología. Actas DermoSifiliográficas 104, 380-392.

Fang, H., Miao, Q., Zhang, S., Cheng, X., Xiong, D., and Zhen, Y. (2011). Antitumor effects of an engineered and energized fusion protein consisting of an anti-CD20 scFv fragment and lidamycin. Science China Life Sciences 54, 255-262.

Fekete, S., Gassner, A.-L., Rudaz, S., Schappler, J., and Guillarme, D. (2013). Analytical strategies for the characterization of therapeutic monoclonal antibodies. TrAC Trends in Analytical Chemistry 42, 74-83. 
Fernández, O., Fernández, V.E., and Guerrero, M. (2015). Tratamiento de la esclerosis múltiple. Medicine - Programa de Formación Médica Continuada Acreditado 11, 4622-4633. Gagnon, P. (1996). Purification tools for monoclonal antibodies.

Gagnon, P., Nian, R., Leong, D., and Hoi, A. (2015). Transient conformational modification of immunoglobulin $\mathrm{G}$ during purification by protein A affinity chromatography. Journal of Chromatography A 1395, 136-142.

Gilbert , S.F. (2006). Developmental Biology . 8th Ed.

Grigorenko, V., Andreeva, I., Rubtsova, M.Y., and Egorov, A. (2015). Recombinant horseradish peroxidase: Production and analytical applications. Biochemistry (Moscow) 80, 408-416.

Gutiérrez-Escolano, A.L. (2006). Inicio de la traducción dependiente de IRES: un mecanismo alternativo para la síntesis de proteínas. REB 2006, 12.

Herter, S., Herting, F., Mundigl, O., Waldhauer, I., Weinzierl, T., Fauti, T., Muth, G., ZieglerLandesberger, D., Van Puijenbroek, E., Lang, S., et al. (2013). Preclinical activity of the type II CD20 antibody GA101 (obinutuzumab) compared with rituximabe and ofatumumab in vitro and in xenograft models. Molecular cancer therapeutics 12, 2031-2042.

Holliger, P., and Hudson, P.J. (2005). Engineered antibody fragments and the rise of single domains. Nature biotechnology 23, 1126-1136.

Hozumi, N., and Tonegawa, S. (1976). Evidence for somatic rearrangement of immunoglobulin genes coding for variable and constant regions. Proceedings of the National Academy of Sciences 73, 3628-3632.

Hwang, W.Y.K., and Foote, J. (2005). Immunogenicity of engineered antibodies. Methods 36, 3-10.

Janeway, C.A., Travers, P., Walport, M., and Shlomchik, M.J. (2001). Immunobiology: the immune system in health and disease, Vol 2 (Churchill Livingstone London).

Jayapal, K.P., Wlaschin, K.F., Hu, W., and Yap, M.G. (2007). Recombinant protein therapeutics from CHO cells-20 years and counting. Chemical Engineering Progress 103, 40. Johnson, N.A., Leach, S., Woolcock, B., deLeeuw, R.J., Bashashati, A., Sehn, L.H., Connors, J.M., Chhanabhai, M., Brooks-Wilson, A., and Gascoyne, R.D. (2009). CD20 mutations involving the rituximabe epitope are rare in diffuse large B-cell lymphomas and are not a significant cause of R-CHOP failure. Haematologica 94, 423-427.

Jung, D., and Alt, F.W. (2004). Unraveling V (D) J recombination: insights into gene regulation. Cell 116, 299-311. 
Kim, J.Y., Kim, Y.-G., and Lee, G.M. (2012). CHO cells in biotechnology for production of recombinant proteins: current state and further potential. Applied microbiology and biotechnology 93, 917-930.

Kim, S.J., Park, Y., and Hong, H.J. (2005). Antibody engineering for the development of therapeutic antibodies. Mol Cells 20, 17-29.

Kito, M., Itami, S., Fukano, Y., Yamana, K., and Shibui, T. (2002). Construction of engineered $\mathrm{CHO}$ strains for high-level production of recombinant proteins. Applied microbiology and biotechnology 60, 442-448.

Klein, C., Lammens, A., Schäfer, W., Georges, G., Schwaiger, M., Mössner, E., Hopfner, K.-P., Umaña, P., and Niederfellner, G. (2012). Epitope interactions of monoclonal antibodies targeting CD20 and their relationship to functional properties. mAbs 5, 22-33.

Köhler, G., and Shulman, M. (1979). Cellular and molecular restrictions of the lymphocyte fusion. In Lymphocyte Hybridomas (Springer), pp. 143-148.

Langone, J.J. (1982). Protein A of Staphylococcus areus and related immunoglobulin receptors produced by streptococci. Adv Immunol 32, 157-252.

Latypov, R.F., Hogan, S., Lau, H., Gadgil, H., and Liu, D. (2012). Elucidation of acidinduced unfolding and aggregation of human immunoglobulin IgG1 and IgG2 Fc. Journal of Biological Chemistry 287, 1381-1396.

Le Hir, H., Nott, A., and Moore, M.J. (2003). How introns influence and enhance eukaryotic gene expression. Trends in biochemical sciences 28, 215-220.

Li, J., Menzel, C., Meier, D., Zhang, C., Dübel, S., and Jostock, T. (2007). A comparative study of different vector designs for the mammalian expression of recombinant $\operatorname{IgG}$ antibodies. Journal of immunological methods 318, 113-124.

LoBuglio, A.F., Wheeler, R.H., Trang, J., Haynes, A., Rogers, K., Harvey, E.B., Sun, L., Ghrayeb, J., and Khazaeli, M.B. (1989). Mouse/human chimeric monoclonal antibody in man: kinetics and immune response. Proceedings of the National Academy of Sciences of the United States of America 86, 4220-4224.

Maloney, D.G. (2012). Anti-CD20 antibody therapy for B-cell lymphomas. New England Journal of Medicine 366, 2008-2016.

MARANHÃO, A.Q., and BRÍGIDO, M.M.d. (2001). Anticorpos humanizados. Biotecnologia, Ciência e Desenvolvimento 23, 38-43.

Marszal, E., and Fowler, E. (2012). Workshop on predictive science of the immunogenicity aspects of particles in biopharmaceutical products. Journal of pharmaceutical sciences 101, 3555-3559. 
Mayes, S., Brown, N., and Illidge, T.M. (2011). New antibody drug treatments for lymphoma. Expert Opinion on Biological Therapy 11, 623-640.

Merino, A.G. (2011). Anticuerpos monoclonales. Aspectos básicos. Neurología 26, 301-306. Miller, J.W. (2004). Tracking G protein-coupled receptor trafficking using Odyssey imaging. Published August by LI-COR Biosciences (http://www. licor. com/bio/PDF/Miller_GPCR. pdf accession date Jan 12 2007).

Montraveta, A., Xargay-Torrent, S., López-Guerra, M., Rosich, L., Pérez-Galán, P., Salaverria, I., Beà, S., Kalko, S.G., de Frias, M., and Campàs, C. (2014). Synergistic antitumor activity of acadesine (AICAR) in combination with the anti-CD20 monoclonal antibody rituximabe in in vivo and in vitro models of mantle cell lymphoma. Oncotarget 5 , 726.

Morrison, S.L., Johnson, M.J., Herzenberg, L.A., and Oi, V.T. (1984). Chimeric human antibody molecules: mouse antigen-binding domains with human constant region domains. Proceedings of the National Academy of Sciences 81, 6851-6855.

Mus-Veteau (2010). <MMB vol.601 Mus-Veteau I. (ed.) Heterologous Expression of Membrane Proteins Methods and Protocols (Humana Press, 2010)(ISBN 1607613433)(272s).pdf .pdf>.

Neuberger, M.S., Ehrenstein, M.R., Rada, C., Sale, J., Batista, F.D., Williams, G., and Milstein, C. (2000). Memory in the B-cell compartment: antibody affinity maturation. Philosophical Transactions of the Royal Society B: Biological Sciences 355, 357-360.

Oflazoglu, E., and Audoly, L.P. (2014). Evolution of anti- CD20 monoclonal antibody therapeutics in oncology. mAbs 2, 14-19.

Papavasiliou, F.N., and Schatz, D.G. (2002). Somatic hypermutation of immunoglobulin genes: merging mechanisms for genetic diversity. Cell 109, S35-S44.

Pateinakis, P., and Pyrpasopoulou, A. (2014). CD20+ B cell depletion in systemic autoimmune diseases: common mechanism of inhibition or disease-specific effect on humoral immunity? Biomed Res Int 2014, 973609.

Pievani, A., Belussi, C., Klein, C., Rambaldi, A., Golay, J., and Introna, M. (2011). Enhanced killing of human B-cell lymphoma targets by combined use of cytokine-induced killer cell (CIK) cultures and anti-CD20 antibodies. Blood 117, 510-518.

Presta, L.G. (2006). Engineering of therapeutic antibodies to minimize immunogenicity and optimize function. Advanced drug delivery reviews 58, 640-656.

Quilici, L., Silva-Pereira, I., Andrade, A., Albuquerque, F., Brigido, M., and Maranhao, A. (2013). A minimal cytomegalovirus intron A variant can improve transgene expression in different mammalian cell lines. Biotechnology letters 35, 21-27. 
Rader, C. (2012). Generation of human Fab libraries for phage display. In Antibody Methods and Protocols (Springer), pp. 53-79.

Schatz, D.G., and Ji, Y. (2011). Recombination centres and the orchestration of V (D) J recombination. Nature Reviews Immunology 11, 251-263.

Schirrmann, T., Al-Halabi, L., Dübel, S., and Hust, M. (2008). Production systems for recombinant antibodies. Front Biosci 13, 4576-4594.

Seiter, K., and Mamorska-Dyga, A. (2015). Obinutuzumab treatment in the elderly patient with chronic lymphocytic leukemia. Clinical interventions in aging 10, 951.

Shuptrine, C.W., Surana, R., and Weiner, L.M. (2012). Monoclonal antibodies for the treatment of cancer. In Seminars in cancer biology (Elsevier), pp. 3-13.

Silva, H.M., Vieira, P.M., Costa, P.L., Pimentel, B.M., Moro, A.M., Kalil, J., Maranhão, A.Q., Coelho, V., and Brigido, M.M. (2009a). Novel humanized anti-CD3 antibodies induce a predominantly immunoregulatory profile in human peripheral blood mononuclear cells. Immunology letters $125,129-136$.

Silva, H.M., Vieira, P.M.M.M., Costa, P.L.N., Pimentel, B.M.S., Moro, A.M., Kalil, J., Maranhão, A.Q., Coelho, V., and Brigido, M.M. (2009b). Novel humanized anti-CD3 antibodies induce a predominantly immunoregulatory profile in human peripheral blood mononuclear cells. Immunology Letters 125, 129-136.

Stank, T.P., and Goldsby, T.J. (2000). A framework for transportation decision making in an integrated supply chain. Supply Chain Management: An International Journal 5, 71-78.

Stathis, A., and Ghielmini, M. (2012). New agents for the treatment of lymphoma. Annals of oncology : official journal of the European Society for Medical Oncology / ESMO 23 Suppl $10, \mathrm{x} 92-98$.

Suen, K.F., Turner, M.S., Gao, F., Liu, B., Althage, A., Slavin, A., Ou, W., Zuo, E., Eckart, M., Ogawa, T., et al. (2010). Transient expression of an IL-23R extracellular domain Fc fusion protein in $\mathrm{CHO}$ vs. HEK cells results in improved plasma exposure. Protein Expression and Purification 71, 96-102.

Thie, H., Meyer, T., Schirrmann, T., Hust, M., and Dubel, S. (2008). Phage display derived therapeutic antibodies. Current pharmaceutical biotechnology 9, 439-446.

Thomas, P., and Smart, T.G. (2005). HEK293 cell line: a vehicle for the expression of recombinant proteins. Journal of pharmacological and toxicological methods 51, 187-200. van Oers, M.H., and Kersten, M.J. (2011). Treatment strategies in advanced stage follicular lymphoma. Best Practice \& Research Clinical Haematology 24, 187-201. 
Vanamala, S.K., Seetharam, S., Yammani, R.R., and Seetharam, B. (2003). Human transcobalamin II receptor binds to Staphylococcus aureus protein A: implications as to its structure and function. Archives of biochemistry and biophysics 411, 204-214.

Varki, A., Cummings, R., Esko, J., Freeze, H., Sanley, J., Bertozzi, C., Hart, G., and Etzler, M. Essentials of Glycobiology, 2009. Part I.

Wang, Y.Z., Tian, F.F., Yan, M., Zhang, J.M., Liu, Q., Lu, J.Y., Zhou, W.B., Yang, H., and Li, J. (2014). Delivery of an miR155 inhibitor by anti - CD20 single - chain antibody into B cells reduces the acetylcholine receptor-specific autoantibodies and ameliorates experimental autoimmune myasthenia gravis. Clinical \& Experimental Immunology 176, 207-221.

Weiner, L.M., Surana, R., and Wang, S. (2010). Monoclonal antibodies: versatile platforms for cancer immunotherapy. Nature Reviews Immunology 10, 317-327.

Wurm, F.M. (2004). Production of recombinant protein therapeutics in cultivated mammalian cells. Nat Biotechnol 22, 1393-1398.

Xu, X., Shi, Y., Cai, Y., Zhang, Q., Yang, F., Chen, H., Gu, Y., Zhang, M., Yu, L., and Yang, T. (2013). Inhibition of increased circulating Tfh cell by anti-CD20 monoclonal antibody in patients with type 1 diabetes. PloS one 8, e79858. 